\title{
0 corpo feminino em (dis)curso: sentidos de (r)existência no digital
}

\section{MELISSA FRANGELLA LOZANO}

Dissertação apresentada à Faculdade de Filosofia, Ciências e Letras de Ribeirão Preto da Universidade de São Paulo como parte das exigências para a obtenção do título de Mestra em Ciências pelo programa de PósGraduação em Psicologia, Área de Concentração: Psicologia: Processos Culturais e Subjetivação.

RIBEIRÃO PRETO 


\section{Universidade de São Paulo}

Faculdade de Filosofia, Ciências e Letras de Ribeirão Preto

Departamento de Psicologia

Melissa Frangella Lozano

O corpo feminino em (dis)curso: sentidos de (r)existência no digital

Dissertação apresentada à Faculdade de Filosofia, Ciências e Letras de Ribeirão Preto da Universidade de São Paulo como parte das exigências para obtenção do título de Mestre em Ciências pelo Programa de Pós-Graduação em Psicologia: Processos Culturais e Subjetivação. 


\section{MELISSA FRANGELLA LOZANO}

O corpo feminino em (dis)curso: sentidos de (r)existência no digital

Dissertação apresentada à Faculdade de Filosofia, Ciências e Letras de Ribeirão Preto da Universidade de São Paulo como parte das exigências para obtenção do título de Mestre em Ciências.

Área de Concentração: Psicologia: Processos Culturais e Subjetivação

Orientadora: Prof. $^{\text {a }}$ Dr. $^{\text {a }}$ Lucília Maria Abrahão e Sousa 
Autorizo a reprodução e divulgação total ou parcial deste trabalho, por qualquer meio convencional ou eletrônico, para fins de estudo e pesquisa, desde que citada a fonte.

Lozano, Melissa Frangella.

O corpo feminino em (dis)curso: sentidos de (r)existência no digital. Ribeirão Preto, 2021.

131 p.:il. ; $30 \mathrm{~cm}$

Dissertação (Mestrado) apresentada à Faculdade de Filosofia, Ciências e Letras de Ribeirão Preto/USP. Área de concentração: Psicologia: Processos Culturais e Subjetivação.

Orientadora: Sousa, Lucília Maria Abrahão e.

1. Digital. 2. Discurso. 3. Mulher. 4. Corpo 


\section{FOLHA DE APROVAÇÃO}

LOZANO, M. F. (2021). O corpo feminino em (dis)curso: sentidos de (r)existência no digital (Dissertação de Mestrado). Departamento de Psicologia, Faculdade de Filosofia, Ciências e Letras de Ribeirão Preto, Universidade de São Paulo, Ribeirão Preto.

Aprovada em: 14 de maio de 2021.

\section{Banca Examinadora:}

Prof. ${ }^{a}$ Dr. ${ }^{a}$ Lucília Maria Abrahão e Sousa

Instituição: Universidade de São Paulo - USP

Prof. $^{\text {a }}$ Dr. ${ }^{\text {a }}$ Cristiane Pereira Costa e Silva

Instituição: Universidade Estadual de Campinas

\section{Prof. ${ }^{a}$ Dr. ${ }^{\text {a }}$ Fabiana Carla Viana Costa Dias}

Instituição: Universidade de São Paulo (Pesquisador colaborador)

\section{Prof. ${ }^{a}$ Dr. ${ }^{a}$ Dantielli Assumpção Garcia.}

Instituição: Universidade Estadual do Oeste do Paraná. 
Dedico este trabalho às mulheres que aventuram-se no estabelecimento de suas tramas discursivas no espaço público, cedendo suas vozes para (d)enunciar e reivindicar outras possibilidades de sentido para o feminino.

Destino também às mulheres de minha família (Mãe, Avó, Tias e Irmã) que foram os pontos cruciais em minha construção subjetiva, onde, um choro, uma indagação e um olhar ganharam contorno, palavras de apoio e também um impossível de se dizer sobre o feminino, trazendo-me até a construção deste trabalho.

Ao meu avô, exemplo de força e determinação. Pelos significantes de amor que foram base para a construção da mulher que eu sou. 


\section{AGRADECIMENTO ESPECIAL}

À Prof. ${ }^{a}$ Dr. ${ }^{a}$ Lucília Maria Abrahão e Sousa.

Obrigada não apenas pelos ensinamentos de uma disciplina até então por mim não conhecida, mas pela reciprocidade da parceria intelectual, pelas poéticas indicações de leitura e olhar e por todo o ambiente de troca construído por você em nosso laboratório.

Agradeço por provocar meu olhar para que eu não o depositasse apenas no que falta, paralisando, mas estimulando-me a direciona-lo para onde meu desejo se encontrava. Sou grata por me ajudar a vislumbrar não só a técnica, o traçado na obra, mas a marca do sujeito, seu traço e sua relação com o contexto sócio, histórico e ideológico em que produz um dizer.

Gratidão por me acolher, orientar e depositar sua confiança em mim e no meu trabalho. Só tenho a agradecer por toda a oportunidade de crescimento que tive com esse processo. 


\section{AGRADECIMENTOS}

Agradeço primeiramente a Deus. Por me guiar e conceder sabedoria para a realização deste trabalho. Por guiar meus passos ao encontro de pessoas que tanto me fizeram crescer, amadurecer e amar.

À minha mãe, por ter me apoiado em todos os momentos. Por me auxiliar a sustentar o desejo pela realização deste trabalho. Pelo investimento de escuta dos meus aprendizados e por todo colo e palavras de apoio em momentos que achei que não conseguiria avançar. Ao seu parceiro, Adalberto por me apoiar nas questões práticas e tecnológicas. Por torcer por mim e confiar em meu potencial.

Às minhas tias por sempre acolherem meu olhar e escuta curiosos acerca do mundo e da sociedade e por incentivarem o meu pensamento e olhar crítico para com estes. Agradeço também por me ouvirem e ajudarem a refletir sobre a minha posição enquanto pesquisadora.

À minha avó por todo apoio e investimento financeiro e afetuoso em minha educação. Pelo carinho, amor e paciência para com minhas investigações e momentos de suspensão. Por compreender meu desejo pela pesquisa.

Ao meu avô, cuja presença física perdi no início desta pesquisa, mas que se fez presente como inspiração de coragem, confiança, perseverança e determinação para comigo e o meu trabalho

À minha irmã e minha amiga Renata, por toda compreensão e ajuda nos momentos de intensa imersão na dissertação. Por me estimularem sempre à dedicar-me e por escutarem mil vezes o mesmo parágrafo sem perderem a paciência.

Aos meus tios, pelas palavras de força e apoio sempre. Por tomarem o feminino em seus sentidos outros, separando-se de uma memória patriarcal.

À Fabíola Ramon pela escuta ética na condução de meus impasses para com o meu trabalho, meu modo de desejar e gozar da vida, sendo o processo de análise imprescindível para a realização desse trabalho.

Ao meu companheiro e namorado Sérgio, por vivenciar comigo o momento final de escrita e defesa deste trabalho, incentivando-me e vivenciando este momento comigo com toda paciência, amor e cuidado do mundo. Obrigada pela leitura atenta, parceria e suporte. Pelas palavras de carinho e confiança. Por seu meu parceiro de reflexões sobre a vida, o humano e a sociedade. Só tenho a agradecer pelo nosso encontro. 
Aos meus colegas de laboratório (El@dis) pelos momentos de discussões e leituras extremamente ricas e que muito engradeceram este trabalho. Pelo convívio, escuta, trocas e por todas as contribuições teóricas essenciais para a construção desta pesquisa.

A todos os meus amigos que foram compreensivos aos momentos de reclusão para o estudo, escrita e reflexão. Agradeço aqueles que estimularam com que eu seguisse a aspiração por fazer mestrado. Em especial, a Carolyne que tanto me apoiou no momento ingresso no mestrado, no decorrer dele e em sua finalização. Obrigada por toda parceria, diálogo e trocas. Hoje e sempre.

À Prof. ${ }^{a}$ Dr. ${ }^{a}$ Cristiane Dias e à Prof. ${ }^{a}$ Dr. ${ }^{a}$ Fabiana Claudia Viana Costa Dias pela leitura atenta, rica e generosa e por suas preciosas contribuições na qualificação e na defesaque tanto clarificaram e impulsionaram o andar desta pesquisa.

À Prof ${ }^{a} \operatorname{Dr}^{\mathrm{a}}$ Dantielli Assumpção Garcia, por acolher o meu trabalho com tanto afeto e generosidade. Se ao longo de sua trajetória profissional contribuiu e contribui para pesquisas sobre a Análise do Discurso e sobre a mulher, honra-me com a sua participação nesta banca de defesa cooperando sobremaneira para o meu crescimento.

Aos funcionários e demais docentes da Universidade de São Paulo, pela dedicação com que conduzem suas atividades. Por tudo o que me foi ensinado e por toda gestão da Universidade que foi local de encontro e trocas inestimáveis.

A agência financiadora CAPES. Por todo apoio financeiro dado no percurso dessa pesquisa.

Por fim, agradeço a todos que fizeram parte desta caminhada e contribuíram para o desenvolvimento não só desta pesquisa, como também, desta pesquisadora, em especial às mulheres que depositamldepositaram seus sentidos em forma de arte tanto na rua quanto na rede, principalmente as mulheres do @projeto.encontrarte e do @lela.brandao (antigo @fridafeminista). 
meninas em gestação de ser mulher meninas que sangram mês a mês possibilidades de si que abortam o que não teve lugar o que não pode ser meninas em gestação mulheres em gesto e ação não colocarei o pau na mesa se você vem com 'porra, porrada, caralho' mostro meus peitos abertos meus seios e anseios fartos dessa gramática de barbárie 


\section{RESUMO}

LOZANO, M. F. (2021). O corpo feminino em (dis)curso: sentidos de (r)existência no digital (Dissertação de Mestrado). Departamento de Psicologia, Faculdade de Filosofia, Ciências e Letras de Ribeirão Preto, Universidade de São Paulo, Ribeirão Preto.

O destaque dado à temática do feminino e os sentidos que circulam sobre ele na sociedade têm permitido reflexões e atualizações de sentido importantes em nosso meio social, principalmente pelo uso das tecnologias de informação e comunicação que, a partir de sua conectividade, tornaram-se uma materialidade imprescindível e facilitadora para a mobilidade de informações e discursos na atualidade. No presente trabalho, teve-se como objetivo principal analisar a forma como o corpo feminino é discursivizado nas obras de arte de lambelambe que são compartilhadas em rede, tendo como referencial teórico-metodológico a Análise de Discurso de filiação francesa. Tal referencial nos possibilita observar os deslizamentos, os furos e a incompletude da língua como parte do processo discursivo. Neste processo, interessaram-nos os gestos de resistência em que arte e poesia se tecem possibilitando o surgimento de sentidos outros acerca desses movimentos e/ou sujeitos em sociedade. Assim, propomo-nos analisar os discursos e os sentidos produzidos sobre/ para a mulher e seu corpo em 17 recortes de posts do Instagram contendo obras de lambe-lambe e comentários postados nestes provenientes de duas contas: @projeto.encontrarte e @lela.brandao (antigo @fridafeminista), que têm a mulher e sua luta por novos sentidos acerca do feminino como mote de suas publicações. A partir dessas materialidades, procuramos não só analisar os sentidos sobre o corpo feminino que circulam em rede nessas contas, mas também compreender de que modo as configurações do digital determinam e dão corpo à relação dos sujeitos com os sentidos sobre o corpo feminino nas obras de lambelambe que circulam em rede; como também, analisar os efeitos de sentido que emergem sobre o corpo feminino inscrito na arte do lambe-lambe. Como alguns dos resultados, por meio das sequências discursivas analisadas, identificamos um duplo emergir de sentidos nos lambes: por um lado, há a denúncia de padrões estéticos dificilmente alcançáveis e segregadores, como também de sentidos de uma cultura de violação do corpo feminino, como se este não pertencesse às mulheres, mas fosse um objeto de uso "público"; por outro lado, há sentidos de resistência a estes tipos de opressão, seja ela estética, seja física. Por se tratar de um material que se estabelece tanto no meio digital como na rua, foi possível observar que mesmo não havendo uma regulação de um dizer nesses espaços, regula-se o encontro com o furo da ideologia dominante a partir das obras dessas contas, permitindo-nos, então, romper com um sentido estabilizado sobre o corpo feminino. Também percebemos que as obras de lambelambe operam como redes de memória a fim de estabilizar um novo dizer, um novo sentido, uma memória outra, sobre o corpo da mulher na atualidade, possibilitando, assim, novas práticas sociais. Desta maneira, essas contas interferem no modo como os sujeitos se encontram e estabelecem relações, estando ligados às atuais condições de produção da contemporaneidade, produzindo novos sentidos sobre o feminino e seu corpo.

Palavras-chave: Digital. Discurso. Mulher. Corpo. 


\begin{abstract}
LOZANO, M. F. (2021). The feminine body in (dis)course: meanings of (r)existence in the digital (Master Dissertation). Department of Psychology, Faculty of Philosophy, Sciences and Arts of Ribeirão Preto, Universidade de São Paulo, Ribeirão Preto.

The emphasis given to the theme of the feminine and the senses that circulate about it in society has allowed important reflections and updates of senses in our social environment, mainly through the use of information and communication Technologies that, from their connectivity, have become a essential and facilitating materiality for the mobility of information and discourse today. In the present paper, the main objective is to analyze the way the female body is discursivized in works of art of lambe-lambe that are shared in a social media, having as a theoretical-methodological reference the Discourse Analysis of French affiliation. Such referential allows us to observe slips, holes and incompleteness of the language as part of the discursive process. In this process, we were interested in the gestures of resistance in which art and poetry are woven, enabling the emergence of other senses about these movements and / or subjects in society. Thus, we propose to analyze the speeches and the senses produced about / for the woman and her body in 17 clippings from Instagram posts containing works of lambe-lambe and comments posted in these from two accounts: @ projeto.encontrarte and @lela.brandao (formerly @ fridafeminista), who have women and their struggle for new senses about the feminine as the motto of their publications. Based on these materialities, we aim not only to analyze the senses about the female body that circulate in social media in these accounts, but also to understand how the digital configurations determine and give shape to the relationship of the subjects with the senses about the female body in the works of lambe-lambe that circulate in a social media; as well as to analyze the effects of sense that emerge on the female body inscribed in the art of lambe-lambe. As some of the results, through the analyzed discursive sequences, we identified a double emergence of senses in the lambes: on the one hand, there is the denunciation of aesthetic patterns that are difficult to reach and segregate, as well as the senses of a culture of violation of the female body, as if it did not belong to women, but was an object of "public" use; on the other hand, there are senses of resistance to these types of oppression, be it aesthetic or physical. As it is a material that is established both in the digital medium and on the street, it was possible to observe that even if there is no regulation of a saying in these spaces, the encounter with the bore of the dominant ideology is regulated from the works of these accounts, allowing us, then, to break with a stabilized sense about the female body. We also perceive that the lambelambe works operate as memory social media in order to stabilize a new saying, a new sense, a different memory, about the womans body today, thus enabling new social practices. In this way, these accounts interfere in the way in which the subjects meet and establish relationships, being linked to the current conditions of contemporary production, producing new senses about the feminine and her body.
\end{abstract}

Keywords: Digital. Speech. Woman. Body. Analysis Discourse. 


\section{LISTA DE FIGURAS}

Figura 1 - Obra da artista visual brasileira Anarkia Boladona ............................................. 14

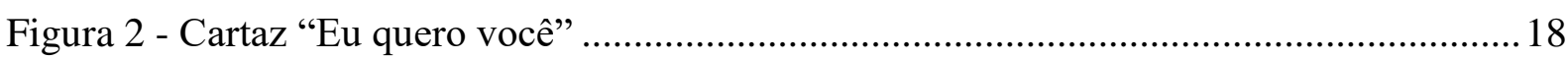

Figura 3 - Cartaz "Manter a calma e seguir em frente" ....................................................... 19

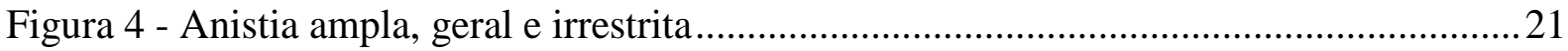

Figura 5 - Obra da artista visual brasileira Anarkia Boladona ................................................ 30

Figura 6 - Obra da artista visual brasileira Nega Hamburguer ............................................54

Figura 7 - Obra da artista visual brasileira Anarkia Boladona ................................................ 75

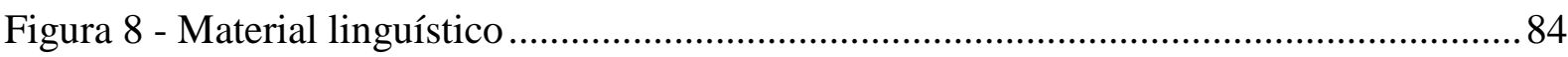

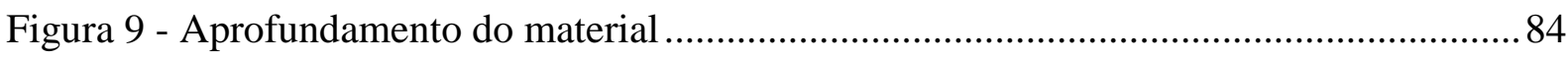

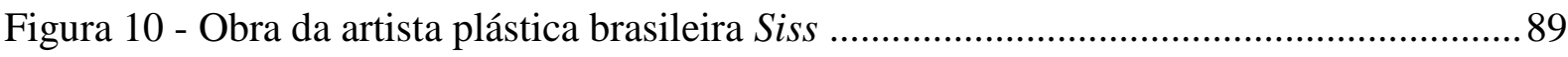

Figura 11 - Postagem do perfil @ lela.brandao no Instagram em 23/05/2017 .......................93

Figura 12 - Postagem do perfil @ lela.brandao no Instagram em 13/03/2017 ........................95

Figura 13 - Postagem do perfil @lela.brandao no Instagram em 16/05/2017 .......................96

Figura 14 - Postagem do perfil @ projeto.encontrarte no Instagram em 11/09/2018 ..............98

Figura 15 - Postagem do perfil @ projeto.encontrarte no Instagram em 10/09/2018 .............. 98

Figura 16 - Postagem do perfil @ projeto.encontrarte no Instagram em 27/04/2018 ............ 101

Figura 17 - Postagem do perfil @ lela.brandao no Instagram em 07/02/2017 ...................... 102

Figura 18 - Postagem do perfil @ lela.brandao no Instagram em 03/05/2017 ...................... 103

Figura 19 - Postagem do perfil @ lela.brandao no Instagram em 08/06/2017 ...................... 107

Figura 20 - Postagem do perfil @ lela.brandao no Instagram em 25/04/2017 ...................... 108

Figura 21 - Postagem do perfil @ lela.brandao no Instagram em 07/12/2016 ...................... 110

Figura 22 - Postagem do perfil @ lela.brandao no Instagram em 10/01/2017 ...................... 112

Figura 23 - Captura de tela da página do Projeto Encontrarte no Facebook .......................... 113

Figura 24 - Postagem do perfil @ projeto.encontrarte no Instagram em 02/04/2018............ 114

Figura 25 - Postagem do perfil @ projeto.encontrarte no Instagram em 01/12/2017............ 115

Figura 26 - Postagem do perfil @ projeto.encontrarte no Instagram em 31/08/2017 ............ 115

Figura 27 - Captura de tela da página do Projeto Encontrarte no Facebook ...........................118

Figura 28 - Obra da artista visual brasileira Nega Hamburguer .......................................... 120

Figura 29 - Obra da artista visual brasileira Nega Hamburguer .......................................... 124 


\section{LISTA DE ABREVIATURAS E SIGLAS}

AAD Análise Automática do Discurso (de Michel Pêcheux)

AAD69 Análise Automática do Discurso publicada em 1969

AD Análise do Discurso

AIE Aparelhos Ideológicos de Estado

FD Formações Discursivas

USP Universidade de São Paulo 


\section{SUMÁRIO}

1 PALAVRAS INICIAIS E TRAJETOS DISCURSIVOS .................................................... 14

\section{A ANÁlISE DO DISCURSO DE LINHA FRANCESA E SEUS CONCEITOS}

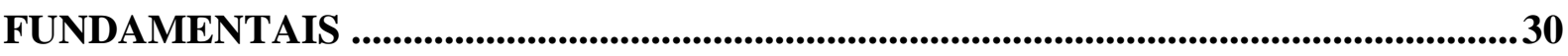

2.1 A AD como ciência e a relação dessa teoria com os objetivos dessa pesquisa...............31

2.2 O tecer de uma teoria e a sua importância para a compreensão de um entrelaçar de

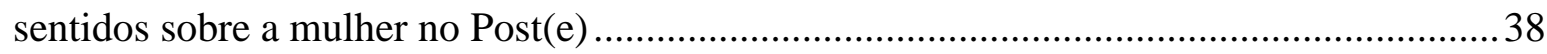

3 REDES E RUAS: UM ESPAÇO EM-COMUM ONDE ARTE E POESIA SE TECEM 4 O MÉTODO DISCURSIVO E SUA ESTRUTURA METODOLÓGICA .......................75

4.1 Considerações metodológicas: o lugar da Análise do discurso nas metodologias de

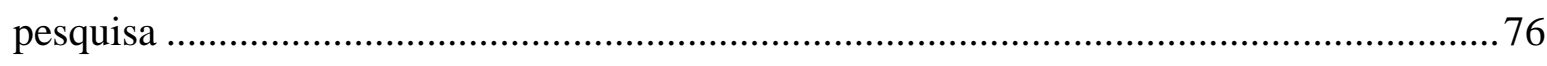

4.2 Condições de produção do corpus de pesquisa ........................................................ 79

5 O FEMININO E(M) DISCURSO: SENTIDOS SOBRE/DO CORPO EM

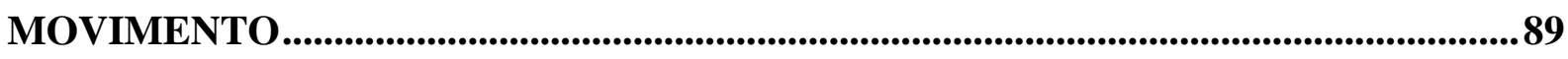

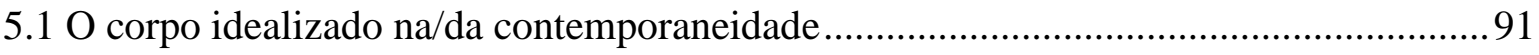

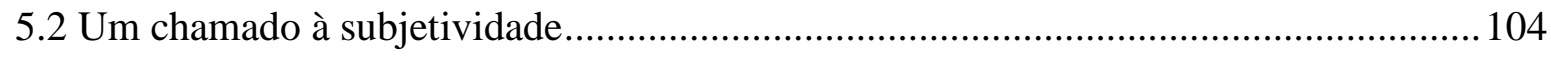

5.3 Um corpo que circula entre o público e o privado .................................................... 114

6 CONSIDERAÇÕES FINAIS............................................................................................................ 120

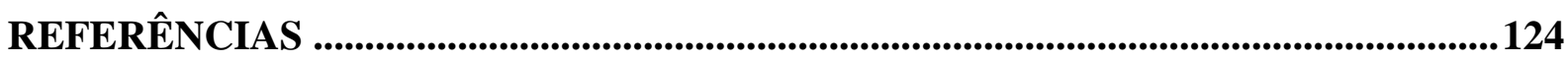




\section{PALAVRAS INICIAIS E TRAJETOS DISCURSIVOS}

Figura 1 - Obra da artista visual brasileira Anarkia Boladona

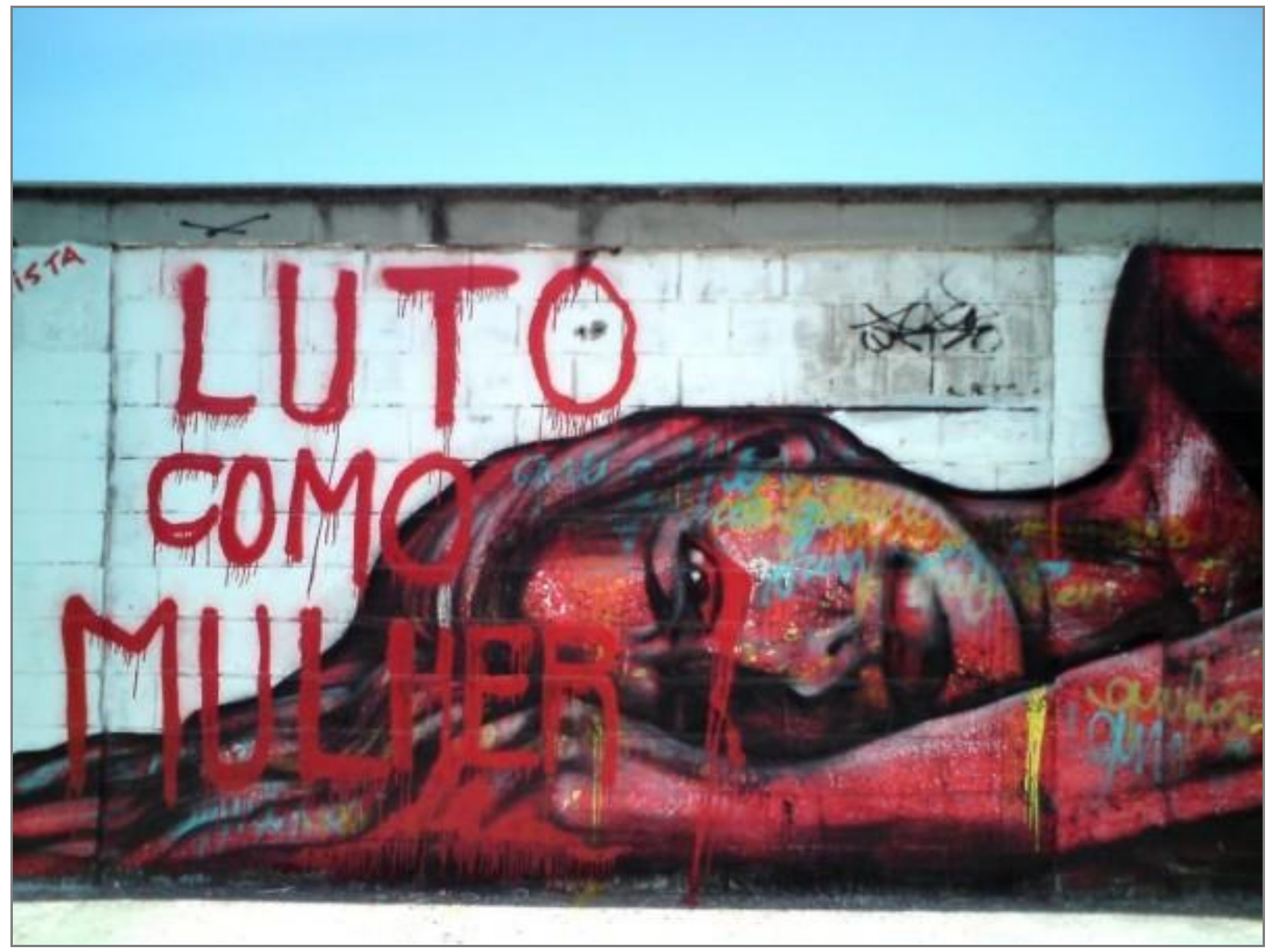

Fonte: http://www.cultureisyourweapon.com/2011/04/anarkia-boladona/

(américa)

uma mulher não é território mesmo assim

lhe plantam bandeiras uma mulher não é souvenir mesmo assim

lhe colam etiquetas mais que nuvem menos que pedra uma mulher não é uma estrada não lhe penetre as cavidades com a fúria de um minerador hispânico o ouro que lhe brota da tez é antes oferenda

(Luiza Romão, 2018) 
Decidi-me pela pós-graduação em Psicologia na FFCLRP/ USP por ser psicóloga e ter interesse em refletir sobre as questões concernentes ao campo da Psicologia, especialmente aos temas ligados à constituição da subjetividade e à linguagem, eixo de pesquisa no qual esta pesquisa está inscrita no programa pós. Motivada por este desejo, cheguei ao nome da Profa. Dra. Lucília Maria Abrahão e Sousa, dona de uma produção bastante rica em Psicanálise e no campo dos estudos discursivos, e, a partir disso, e do aceite da professora, a possibilidade de estudar temas que já eram do meu interesse se tornou mais próxima de se concretizar.

A escolha da orientadora e o laboratório se encaixaram perfeitamente dentro dos meus objetivos, já que a Professora Lucília promove, em seus espaços de pesquisas, leituras e debates que, na perspectiva teórica e metodológica da Análise do Discurso de matriz francesa, envolvem os sentidos produzidos pelo discurso midiático e suas novas práticas, seus significados sociais e culturais, analisando como esses afetam a subjetividade, a constituição do sujeito e a sua relação com o corpo e o mundo.

Por dar enfoque ao processo de subjetivação do sujeito em sua relação com contextos culturais diversos, refletimos juntas que promover estudos relacionados à dinâmica cultural e à linguagem abriria espaço para ampliar o meu estudo acerca no sujeito discursivo dentro do âmbito da Análise de Discurso. O meu percurso intelectual, acadêmico e profissional, desde o ingresso no curso de Psicologia, foi lentamente me colocando em proximidade com a questão do sujeito, sua subjetividade e sua relação com o meio em que vive, tendo estas reflexões despertado em mim o interesse pelo estudo e investigação do ser humano em sociedade. De pesquisadora de iniciação científica a psicóloga atuante, interessada pela teoria e prática da Psicanálise, sempre estive próxima a leituras e debates acerca do sujeito e sua relação com a linguagem.

O desejo em me desenvolver frente ao trabalho acadêmico não cessou da graduação até minhas práticas profissionais. Desse modo, alguns anos após iniciar minha atuação como psicóloga, decidi que era o momento de retornar para o mundo acadêmico e ingressar em uma pós-graduação. A escolha do tema para o projeto de mestrado não foi difícil, já que a arte urbana e seu modo de significar em mim sempre foi uma temática que me pôs a refletir em meus passeios pela cidade de São Paulo. Fui criada em uma cidade do interior de São Paulo, Ribeirão Preto, precisamente em um bairro de classe média alta, onde as expressões de arte encontravam-se sempre no interior de algum local (museus, casas particulares etc.), enquanto propriedade de alguém ou do estado/município. Ou seja, para apreciarmos as obras era necessário irmos até o local onde estavam expostas, confinadas. 
Ao me deparar com uma arte "livre" e em um ambiente de intensa circulação humana, fiquei encantada, o que me fez estabelecer alguns questionamentos: Quem seriam aqueles artistas? O que estavam ali a dizer para a cidade e mais precisamente para mim? Ao questionar alguns membros da minha família sobre tal manifestação, alguns a chamavam de transgressão, vadiagem e crime; outros me levaram a perceber a sua poética e importância no ambiente no qual essas expressões artísticas circundam. Pairou, então, sobre minha cabeça uma questão primordial: Que a arte/objeto seria aquela que produz inúmeros dizeres e sentidos em minha família? Durante a minha trajetória profissional, a oportunidade de trabalhar com um público marginalizado e que tinha profundo interesse por manifestações artísticas que diziam da periferia (grafite, pichações, o rap e a arte urbana), da segregação que sofriam e das frustrações originadas do mundo capitalista, no qual não conseguia se inserir, adicionou outra perspectiva nesta minha experiência. Nesse momento, foi possível ver a arte urbana novamente em minha vida, dizendo um pouco do sentimento de crianças/adolescentes e adultos. Assim, outros sujeitos puderam ser considerados em meus questionamentos, tendo a minha indagação inicial se ampliado para: Que arte/objeto seria aquela que produz inúmeros dizeres e sentidos na sociedade?

Mais adulta, passei a observar esse movimento das ruas aparecendo também nas redes sociais, estabelecendo ali redes de sentido que me convocavam novamente a refletir sobre o sujeito e sua posição no espaço público, podendo ser este o da rua, como também, o da rede, o espaço virtual. Os gestos de ler, retomar a história, dar sentidos, associar e refletir sobre associações já pré-estabelecidas são movimentos que sempre estiveram muito vivos em meu modo de experimentar o mundo, sendo estes desejos alimentados e estimulados em minha infância. E foi a partir dessa incidência que enderecei meu desejo à Prof. ${ }^{a}$ Dr. ${ }^{a}$ Lucília. A partir desse momento, neste texto, deixo a primeira pessoa do singular e passo a usar a primeira do plural, nós, já que tal pesquisa se estabeleceu em um movimento de sentidos conjunto entre minha orientadora, eu e os demais teóricos da Análise de Discurso.

A partir desse trabalho, realizamos um esforço de legitimar esta voz e esse desejo de saber que não cessaram de instigar o movimento dessa pesquisa: Que objeto é este, o da arte, que produz inúmeros dizeres e sentidos na sociedade? Nesse projeto de mestrado, há a tentativa de dar um norte para essa questão, sinalizando um mergulho inicial em um contexto que não cessa de reclamar sentidos e inscrever dizeres.

Em tempos como os de hoje, em que grupos minoritários (mulheres, comunidade LGBTQI+, negros e indígenas) são em sua maioria atacados, todo texto do qual parte uma perspectiva social que luta contra a invisibilidade de um dizer ou sujeito torna-se 
inevitavelmente um gesto de resistência, um gesto político. Nesse sentido, podemos dizer que a arte de rua pode ser vista como um grito de alerta que encontra, nesse espaço, o potencial de realizar rupturas com o mundo, fazendo falar ali sentidos cristalizados e/ou deslocados dos que circulam como hegemônico, além de produzir novos sentidos, (re)existindo.

Dessa forma, investigar as marcas de expressão deixadas na cidade é de extrema importância para compreender as lutas políticas do cenário atual de nosso país. Do caos imagético à fragmentação territorial, o acúmulo e superficialidade de signos, a cidade se ergue em suas pungentes possibilidades de simbolização. É na cidade que subjetividades são constituídas, ocorrendo por meio de grupos que formulam dizeres outros, que resistem ao já instituído e buscam potencialidades outras de viver e existir inscritos nesse espaço.

Um bom exemplo desse movimento é o resultado da reunião de Ryane Leão e Lela Brandão (Ryane toca o projeto "Se essa rua fosse nossa" e "Onde jazz meu coração" e Lela o "Frida Feminista") que, por meio da construção de oficinas de lambe-lambe, voltadas à mulheres para expressar as violências já vividas em nossa sociedade, ocasionou um grande movimento de romper e desestabilizar sentidos cristalizados sobre a mulher em nossa sociedade, fazendo, dessa forma, um levante de outros tantos projetos como o projeto Encontrarte, entre outros (Warken, 2016). Nesse caminho, salientamos que a produção desses projetos não se encontra somente na rua, mas tem também seu resultado descrito e mostrado nas suas redes sociais como, por exemplo, o Facebook e o Instagram.

Em virtude disso, nossas indagações se estendem justamente sobre o modo como essa apropriação do espaço público vem sendo produzida e as maneiras possíveis de se formular e constituir outros dizeres que possibilitem outras formas de existência. Consideramos o lambelambe, assim como outras formas de arte urbana, uma forma de manifestação emergente de grupos e pessoas que, ao intervir na cidade, produzem uma discursividade e uma cidade outra.

Consideramos importante compreender como os sentidos se constituíram sóciohistoricamente por meio dos lambe-lambes, assim, iremos recuperar a historicidade deles. Segundo Oliveira (2015), a prática de colar cartazes é antiga, já tendo existido nos mais diversos formatos e (re)produzidos com os mais variados objetivos como, por exemplo, para convocar os jovens a participarem da guerra, como foi feito na Primeira Guerra Mundial (1914 - 1918) e na Segunda Guerra, tendo seu uso o objetivo de provocar o sentimento de revolta e raiva em relação às nações inimigas, explorando, assim, conceitos de glória nacional e coragem militar ou, ainda, utilizado para acalmar a população frente ao agravamento da batalha. 
Figura 2 - Cartaz "Eu quero você"”

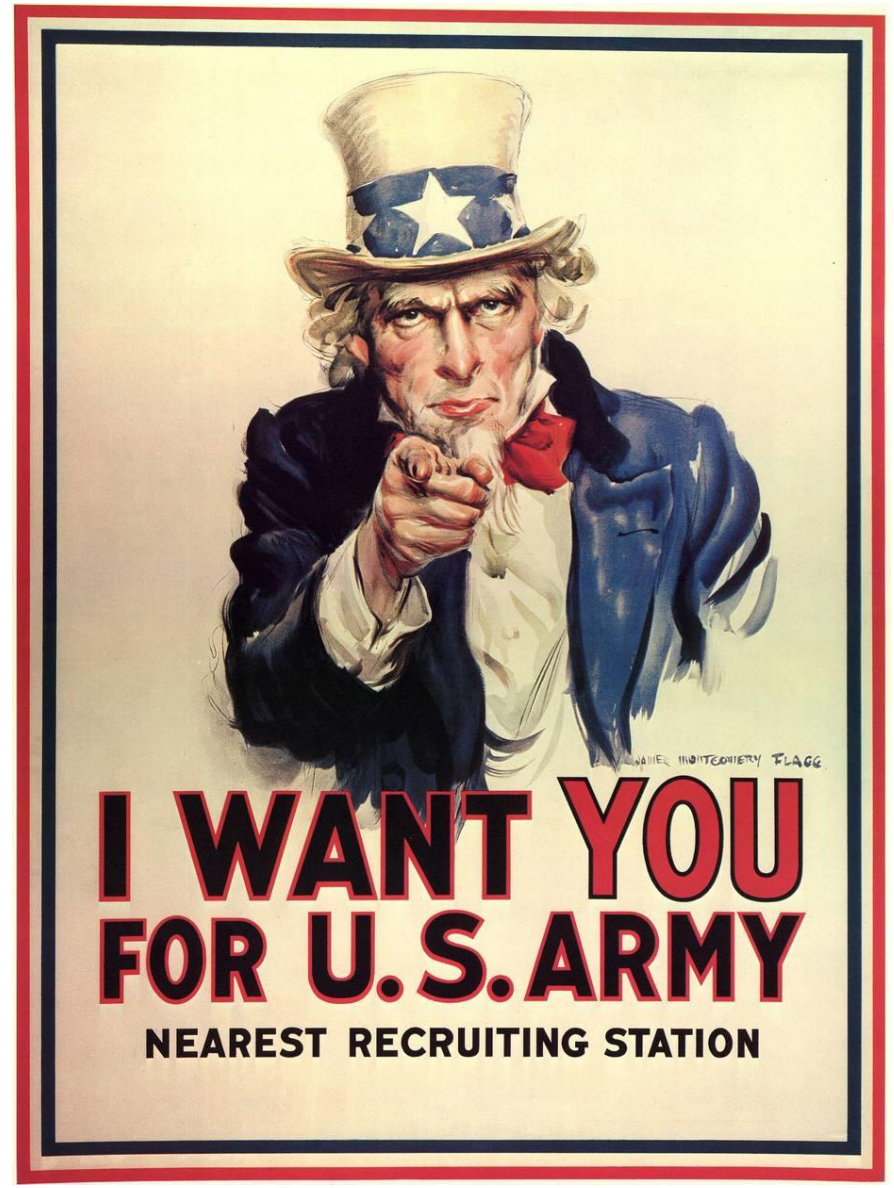

Fonte: Estadão (2017)

Neste primeiro cartaz, a imagem foi ilustrada com o objetivo de se tornar um elemento de propaganda para convocar os jovens a participarem da guerra, tornando-se uma ferramenta de recrutamento para um posicionamento sócio-histórico e ideológico. Ou seja, "Tio Sam" aponta o dedo, com um olhar assertivo, e dá a ordem: "Eu quero-te no exército dos EUA" (em inglês: "I Want You for U.S. Army")2, observamos uma convocação que o sujeito se inscrevesse discursivamente, que toma uma posição com relação a esse confronto.

\footnotetext{
${ }^{1}$ Cartaz usado com o propósito de atrair recrutas para lutar na Primeira Guerra Mundial.

2 Tradução livre.
} 
Figura 3 - Cartaz "Manter a calma e seguir em frente"3

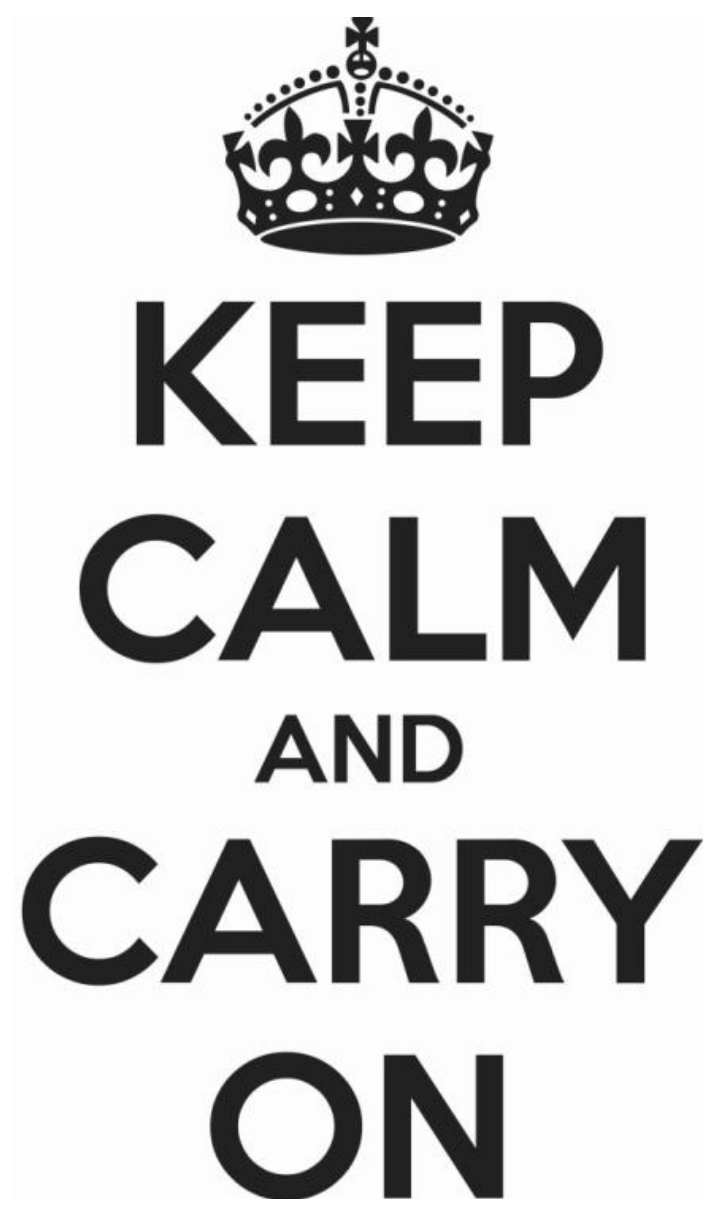

Fonte: Yahn (2012)

Observemos o cartaz acima, que irrompeu em um outro momento na história, inscrito em uma outra condição de produção, mas seu objetivo, assim como a imagem anterior, voltase ao processo de comunicar com a sociedade em tempo de guerra. Em 1939, o governo britânico encomendou três cartazes para acalmar a população. O primeiro dizia: “A liberdade está em perigo. Defenda- a com toda a sua força", o segundo dizia "Sua coragem, sua alegria e sua determinação vão nos trazer a vitória” e, por fim, a última mensagem era bem mais curta e direta "Mantenha a calma e siga em frente" (o cartaz acima). Diante de tais obras produzidas, foram impressos 2,5 milhões de 'Keep Calm and Carry On' (Mantenha a calma e continue $^{4}$ ). $\mathrm{O}$ plano era divulgar os pôsteres em caso de invasão alemã para acalmar os britânicos durante esse tempo difícil que poderia se aproximar, mas que nunca aconteceu.

O enunciado apresentado tem, então, como objetivo interpelar os sujeitos a uma tomada de posição, o de manter a calma, de não se desesperar ou de se manifestar contra a

\footnotetext{
${ }^{3}$ Cartaz organizado pelo governo britânico na segunda Guerra Mundial, tendo por objetivo principal acalmar a população durante os tempos difíceis que se aproximavam.

${ }^{4}$ Tradução livre.
} 
guerra, mas apenas de seguir cumprindo o seu "dever social" enquanto cidadão britânico. Diante disso, tal discurso colabora na/com a produção da ilusão de autonomia do sujeito em se posicionar com relação à guerra ou até de temê-la.

Oliveira (2015) aponta-nos que no Brasil o cartaz foi utilizado como forma de expressão contra a repressão dos governos totalitários, em que parte da população e das organizações contrárias ao regime saíam às ruas para protestar e colavam cartazes reivindicando direitos e o fim do militarismo. No entanto, ao mesmo tempo, o mesmo mecanismo era utilizado pelos militares para atingir e capturar os cidadãos contrários ao militarismo ao serem colocados cartazes, por exemplo, de pessoas que ficaram conhecidas como "terroristas", que lutavam pela liberdade de expressão, entre outros direitos.

Nesse primeiro recorte, há uma colagem, um cartaz, com fins propagandísticos da anistia com o slogan "NÃO QUEREMOS LIBERDADE PELA METADE”, objetivando, assim, mobilizar a população em prol dessa causa, a liberdade para aqueles que foram contra os ideais e sentidos estabilizados por uma parte da comunidade. O próprio título e o conjunto do cartaz problematizam um ponto dessa arena de disputas sociais com as seguintes afirmações: "a anistia não concedida aos presos nomeados de terroristas durante a ditadura"; “a não autorização do retorno dos exilados" e, por último, "solucionar os desaparecimentos e o proporcionar justiça aos mortas pela ditadura". Ou seja, este cartaz torna-se um clamor por uma liberdade a todos. 
Figura 4 - Anistia ampla, geral e irrestrita ${ }^{5}$

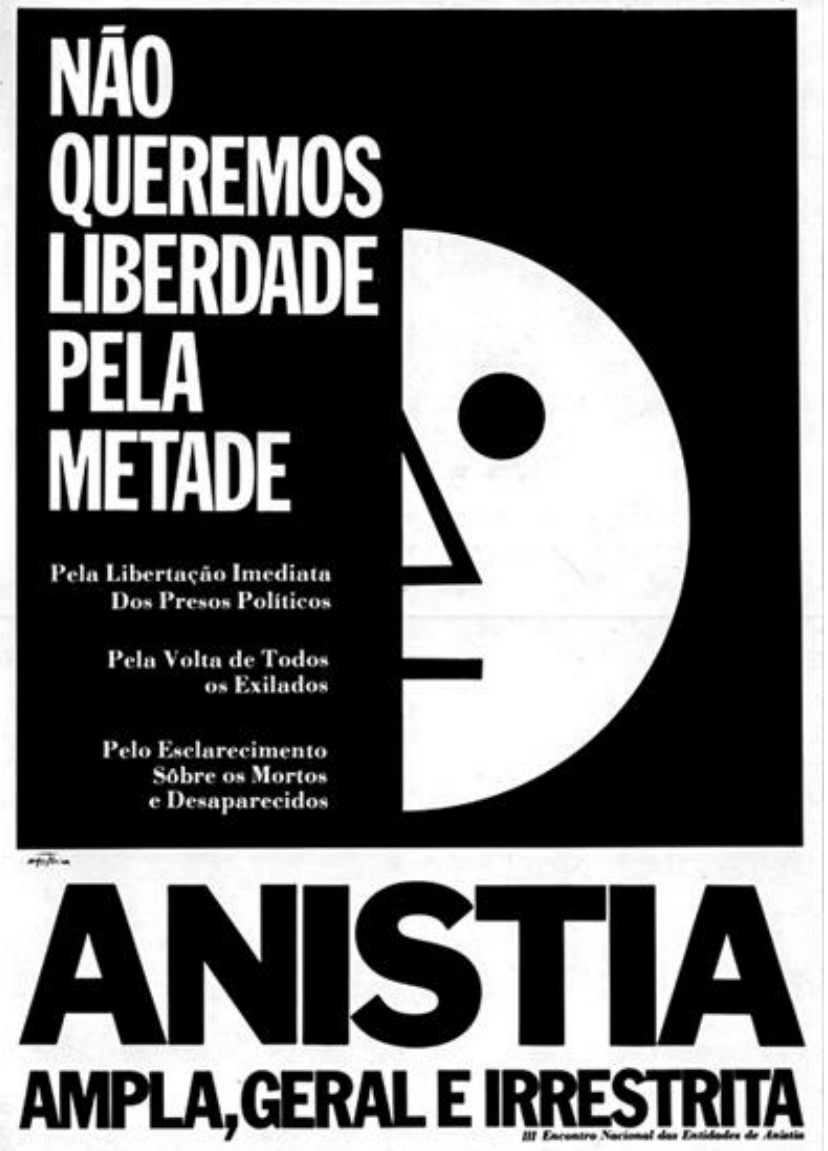

Fonte: Westin (2019)

Com a evolução da tecnologia, da estética e do pensamento de cada época houve uma transformação nos cartazes que, segundo Oliveira (2015), diferenciaram-se por ter cada um seu objetivo e um sentido diferente a ser depositado no urbano. Esses materiais podem ser subdivididos em cartaz, pôster e lambe-lambe. O cartaz tem seu valor funcional para a comercialização de algo, além disso, está relacionado à propagação de uma ideia, de um produto ou de um serviço. O pôster, por exemplo, tem valor estético, decorativo e, em geral, é colocado em espaços privados. Já o lambe-lambe tem o cartaz como seu precursor, no entanto, seu objetivo é outro, já que está relacionado a um movimento com viés crítico e tem como objetivo promover uma ideia ou uma reflexão contrária à conduta social ou à desigualdade. Normalmente é resultado do trabalho de artistas e grupos de artistas que ocupam o espaço público com o objetivo de espalhar suas criações. Vemos, hoje, muitos lambe-lambes reutilizando, aproveitando e até mesmo "roubando" o espaço de veiculação de lugares que, geralmente, estão abandonados e deixam espaços vazios (como caixas de

\footnotetext{
${ }^{5}$ Cartaz contra a ditadura militar no Brasil, exigindo liberdade aos presos políticos contrários ao regime.
} 
telefone público, muros e postes), passando a ter outra função, a de veicular um dizer. Dessa forma, observamos que cada artista se propõe a inscrever sentidos no urbano, sendo um modo de relação do sujeito com a cidade.

De acordo com Nascimento, Souza e Torezani (2017), a arte do lambe-lambe caracteriza-se por uma forma específica de intervenção que percorre locais e busca evidenciar relações causais de transformação do espaço social. Assim, seu gênero vai além de uma pura concepção artística, servindo, também, como ferramenta comunicacional utilizada por grupos de minorias. Esse gênero artístico é acessível a qualquer nível social por possuir um caráter reinvidicativo, além de ter um baixo custo de produção que, atualmente, se espalhou não só pelas periferias.

Em virtude disso, "o lambe-lambe nada mais é do que um pôster que se tornou uma expressão artística e política, colado nas ruas dos centros urbanos" e suas "temáticas, formas e estilos são as mais variadas, de simples cartazes com textos impressos até outras criações artísticas mais elaboradas" (NASCIMENTO; SOUZA; TOREZANI, 2017, p. 3). Na contemporaneidade, o lambe-lambe é uma forma de arte urbana que dispõe tanto de um movimento de linha crítica, propondo uma reflexão contrária à alguma atitude, desigualdade ou norma social quanto simplesmente como forma de expressão do artista que o cria, usando do espaço social para expor as suas obras.

Conforme Oliveira (2015), em 2013, após os protestos ocorridos em junho em várias capitais do Brasil, reivindicando a suspensão do aumento da tarifa de ônibus e a implantação do transporte público gratuito, organizados pelo Movimento Passe Livre (MPL), a circulação das obras de arte urbanas nas ruas e nas redes se tornaram um importante aliado para divulgar a agenda de mobilidade urbana do grupo e as ações programadas para efetivá-la em São Paulo. A partir desse acontecimento, de grande repercussão em todo o país, essa forma de mídia alternativa se popularizou no território de São Paulo, principalmente nas regiões centrais, onde é possível identificar obras com diferentes discursos e narrativas.

Para Orlandi (2004, p. 12), “observar a cidade é procurar compreender as alterações que se dão na natureza humana e na ordem social”, ademais, devemos compreender:

[...] a riqueza que se mostra na relação do indivíduo com outros indivíduos e com tudo que constitui a cidade. Heterogeneidade mas padronização, subordinação à exigências da comunidade maior na medida em que faz parte de movimentos coletivos, mas, ao mesmo tempo, dispersão, e, ainda, individualidade (Orlandi, 2004, p. 12).

Logo, observar esse movimento da/na cidade é também analisar uma mudança no humano e em sua sociedade. No caso desta pesquisa, isso está presente nas obras pretendemos 
analisar, com o objetivo de questionar como os sujeitos se (res)significam por meio da linguagem e a outros através desta.

Todavia, chamou-nos a atenção o fato de as redes sociais se tornarem também um espaço de manifestação, promoção de campanhas e reivindicação de uma escuta, em que é preciso olhar para determinados sujeitos ou causas sociais. Conforme Pereira (2018), se refletirmos sobre as manifestações de rua que marcaram o início de 2010 - a Primavera Árabe (2011) ou as Manifestações de Junho no Brasil (Movimento Passe Livre) (2013), por exemplo - podemos compreender o movimento dessas manifestações não só nas ruas, mas também nas redes, em que tinham em sua materialidade o potencial forte de organização e reunião com o propósito da resistência, proporcionando, desse modo, certas condições para a irrupção desses acontecimentos, que será melhor descrito nos capítulos a seguir. A partir disso, Pereira (2018) problematiza o espaço urbano nessas manifestações, em que ele é tomado como um "espaço simbólico trabalhado em/pela história, um espaço de sujeitos e de significantes" (Orlandi, 2001, p. 186), passando a ser ressignificado pelos instrumentos e aparatos tecnológicos. Nesse caminho de reflexão, acompanhamos, hoje, um sujeito que se individualiza em seus modos, que se identifica e produz sentidos sobre si e sobre o outro tanto na rua como na rede. A conectividade existente, hoje, tornou-se uma característica imprescindível para a mobilidade contemporânea, já que, graças a essa, foi e ainda é possível que movimentos urbanos contemporâneos e formas de organização do espaço e de instituições se encontrem a fim de possibilitar novos processos de (re)significação dos sentidos.

Segundo Dias (2018), podemos pensar a mobilidade como conectividade, pois esta se instaura a partir da existência de dispositivos conectados uns aos outros, bem como sujeitos ligados uns aos outros. Segundo a autora, na hodiernidade, a organização de uma sociabilidade e de novos laços sociais não se limita mais à definição de fronteiras espaciais ou temporais. Elas se estendem pelas redes sociais onde o laço tende a se antecipar ao local físico do encontro. Com isso:

\footnotetext{
o que define mobilidade não é necessariamente o mover-se no espaço, de um ponto ao outro, mas mover-se em rede, entre-nós. O que define a mobilidade é a conectividade. E essa conectividade tem a ver com os laços sociais e com os processos de identificação do sujeito. (Dias, 2018, p. 126).

Tendo em mente esta conectividade e os laços sociais, podemos vislumbrar inúmeros eventos em que grupos minoritários (mulheres, comunidade LGBTQI+, negros e indígenas, entre outros) são em sua maioria atacados, e que, em contrapartida a estes ataques, vem-se apresentando por meio de gestos nas redes sociais que partem de uma perspectiva social que
} 
luta contra a invisibilidade de um dizer ou de sujeitos, denunciando toda a violência por eles sofrida, tornando-se inevitavelmente um gesto de resistência.

Esses gestos se apresentam hoje na rua, na rede e, na maioria das vezes, entre ambas as instâncias. Segundo Dias (2012, p. 17)

[...] o ciberespaço está por toda parte constituindo o real da cidade, do espaço urbano, tecendo novas formas de relação entre os sujeitos, com uma linguagem própria, uma temporalidade outra. Novas formas de identidade, de subjetividade, construindo o espaço tempo virtual.

Nesse sentido, e a partir do material que nos interessa compreender, tomamos essas manifestações como estando em uma mesma rede, onde arte e poesia se tecem. Não iremos pensá-las como instâncias separadas onde o on e o off-line atuam separadamente, mas como movimentos de um espaço em-comum. Confirmando esse nosso trajeto, Dias (2018) nos aponta que rede e rua produzem sentidos para um trabalho do "em-comum", sendo esta possibilidade o elemento que traz a potência do político (elemento constitutivo que é próprio das relações: a diferença) ressurgir, afastando o apagamento que ocorre pela violência derivada da anulação das diferenças e que é própria do congelamento da relação.

Mais do que isso, não propomos uma relação de equivalência entre rua e rede, mas de transferência pelo efeito metafórico entre elas, sem apagar a singularidade de cada uma. No digital, o efeito é outro do que o da surpresa da rua, mas o que nos interessa é o entremeio entre elas, essa relação metafórica onde elas se cruzam, o em-comum. A esse respeito, podemos perceber que tanto na rua, como na rede as obras são compartilhas de forma muito veloz, rápida e de fácil reprodução. A rua, por ser proibida a colagem desses cartais, há sempre um risco, exigindo a rapidez em sua colocação. Além disso, o próprio uso de algo já impresso, bastando passar uma cola em cima já deixa o processo mais rápido e fácil de se reproduzir. O digital por sua vez, pela rapidez que as informações circulam e a acessibilidade em compartilhar as obras também tornam o processo veloz e de fácil reprodução. Outro ponto de equivalência é o fato de tanto na rua, quanto na rede, ser possível perceber a presença dessas instâncias, seja pela presença de um poste, muro ou o circular das pessoas nas obras compartilhadas em rede, seja pelo @ que sempre acompanha os cartazes.

Também podemos tomar esta violência como sendo discursiva, já que o funcionamento discursivo, que funciona em dois eixos (o do interdiscurso e o intradiscurso), aponta-nos para a existência de um dizer anterior, já sedimentado de um enunciado, do qual o sujeito não é origem. No entanto, este sujeito também garante a possibilidade de atualização de um dizer via a formulação do enunciado a partir de uma prática discursiva inserida em condições de produção específicas e nunca idênticas. A atenção para aos conceitos de 
paráfrase e polissemia permitem um exercício de visualização da evolução dessa materialidade significante ontem e hoje. Assim, torna-se mais evidente àquele que deposita seu olhar analítico aos confrontos políticos e históricos existentes em determinadas formações discursivas a existência de um jogo entre os sentidos já estabilizados e os que vêm para romper com estes, cuja observação só é possível pela movência da língua, que se dá nas materialidades.

A partir disso, podemos considerar que esse espaço "em-comum" possibilita a tensão entre o já dito e a possibilidade de dizer, proporcionando a retomada, a ressignificação e a atualização de uma formação discursiva, marcando a origem da natureza do singular do dizer e dos gestos de leitura que tanto lhe antecedem como seguem. Dessa forma, ao tomarmos discursivamente este espaço "em-comum", estamos possibilitando a escuta de sentidos antes silenciados ou em não evidência, possibilitando uma rede ampliada capaz de produzir na cidade outros sentidos possíveis. Dias (2018) coloca que a mobilidade está estritamente ligada às mídias sociais hoje, na medida em que, por meio delas, é possível uma mudança na maneira dos sujeitos se relacionarem, modificando a maneira como o sujeito faz seus trajetos no espaço da cidade e se apropria dos conhecimentos tanto subjetiva quanto socialmente.

Assim, a conectividade (im)posta nas redes sociais pressupõe a formação de um círculo de sociabilidade virtual que se comunica formando, conforme a autora, uma rede de dizeres de si e do outro que se entrelaçam, constituindo uma dispersão de outros. Em virtude disso, para dizer de/sobre si, o sujeito, ao publicar, marca uma posição que pode ser da ruptura com dizeres já cristalizados e/ou que segue a ordem do naturalizado e da evidência ideológica, endereçando esse discurso posto no post a um outro sujeito enquanto uma verdade absoluta. Este trabalho, materializado como um discurso no interior das práticas sociais, é afetado por essas condições de produção, é por meio desse contexto no qual nos sentimos convocados a depositar o nosso olhar e a nossa "escuta", além de compreender a relação das configurações do digital com a circulação e atualização dos sentidos em rede.

A temática do feminino hoje passa por inúmeros atravessamentos teóricos, nas mais diversas áreas de discussão sobre luta por igualdade de direitos de gênero. Estes promovem mudanças e rupturas que pudemos observar e experimentar nas últimas décadas em nosso país. O livro "Explosão feminista: arte, cultura, política e universidade", organizado por Heloísa Buarque de Hollanda (2018), é um desses modos de repensar o papel da mulher hoje em nossa sociedade. A obra acena ao leitor um movimento de reflexão acerca do significado do movimento de mulheres na hodiernidade, com um olhar especial aos seus nuances, como a tentativa de estabelecer uma luta plural, com a inclusão das mais diversas vozes de mulheres 
que buscam por mais igualdade, combinando, assim, eixos como os de: gênero, classe, raça, etnia, orientação sexual, deficiência, religião etc. Assim, Hollanda (2018) apresenta esse movimento em nosso país como sendo um movimento de massas, dando evidência ao papel das ferramentas de comunicação digital para difusão de um ideário de como a mulher deve ser tomada pelo social hoje.

Nas reflexões postas na obra de Hollanda (2018), dois eixos se destacam. O primeiro questiona a imagem de mulher tomada como padrão no Brasil: branca e possuidora de um "corpo natural", reforçando também a noção de uma mulher determinada pela biologia. $\mathrm{O}$ segundo aspecto diz respeito a como o debate e a teoria dos feminismos, ainda hoje, não acomoda os horizontes e experiências de várias mulheres, mesmo sendo esse movimento por igualdade ainda desigual. Compreendemos, então, a partir da obra "Explosão feminista: arte, cultura, política e universidade", que as redes sociais se tornaram peça fundamental para a luta de novos sentidos acerca da mulher em sociedade, contribuindo para a produção de novas subjetividades, conexões e solidariedades e a articulação do ambiente virtual e não virtual. No entanto, a partir dessa obra, percebemos que as redes sociais atuam como suportes horizontais e neutros de conexão e propagação de informação. Para as autoras, as redes têm seu funcionamento determinado por corporações que estimulam configurações particulares de difusão de informação. Assim, essas determinações estabelecem maneiras específicas de fazer e circular a informação, afetando a percepção e a interação dos usuários.

Com as manifestações e os protestos sociais no Brasil a partir de 2013, foi possível observar uma retomada de sentidos das manifestações ocorridas nas ruas para as redes sociais, estabelecendo novos gestos de circulação de dizeres que rompem com os ditos estabilizados ideologicamente em nossa contemporaneidade. Nesse caminho, com uma vastidão de obras de arte que migraram (e ainda migram) da rua para a rede, decidimos atentar-nos para algumas artistas que compartilham em seus perfis no Instagram obras de lambe-lambe (obras de arte urbanas), que circulam outros sentidos sobre o corpo da mulher e instalam novos discursos sobre o feminino, responsáveis por romper com dizeres já estabelecidos e estabilizados numa formação social. Estabelecidos justamente porque deixamos de se perguntar sobre a própria luta, sendo assim, importante o gesto de tais artistas, que utilizam-se tanto da rua quanto da rede veiculam sentidos de (re)existência ao discursivizar. Muitas imagens de seus trabalhos são compartilhadas em seus perfis digitais - Instagram e Facebook - pelas próprias artistas/coletivos, encontrando espaço e visibilidade para além do contexto local em que são reproduzidas no urbano. Tais perfis funcionam como coletâneas de suas intervenções 
artísticas, sendo esse o arquivo no qual empreenderemos um olhar analítico nas próximas páginas.

Uma das formas da incidência da conectividade para incidência do político, que abordamos nesse trabalho, diz respeito aos efeitos discursivos das obras compartilhadas nos perfis: @projeto.encontrarte; @leda.brandao (antigo @ fridafeminista, sendo este@ @ue acompanha muitas das obras) que se utilizam de fotografias de obras de lambe-lambe (obras de arte urbana), de cunho feminista, para compartilhar dizeres sobre o feminino neste lugar em-comum da rede e da rua, textualizando, assim, gestos políticos de resistência e os deslocamentos produzidos por uma ruptura da memória discursiva acerca da mulher.

O projeto Encontrar(te $)^{6}$ tem origem no encontro de mulheres que sofriam de violências (físicas e psicológicas) em relacionamentos e vivências abusivas. Aline Fidalgo, 35, e Mari Vieira, 40, se encontraram com Ryane Leão, 27, do projeto Onde Jazz Meu Coração, e com a estudante de arquitetura Lela Brandão, 22, do Frida Feminista, dando início a dois projetos que reuniriam outras mulheres: o Projeto Encontrarte, de Mari e Aline, e o Manifesto das Minas, de Bianca Maciel, 21. Sendo estes oficinas da lambe-lambe nas ruas, que também iriam circular nas redes sociais do projeto, marcando a união de espaço material e espaço virtual.

Já o perfil Frida Feminista ${ }^{7}$, surge do projeto da artista e estudante de arquitetura Lela Brandão, cujo objetivo era "passar mensagens sobre autoestima e empoderamento às mulheres, com frases positivas, que vão contra a gordofobia e a padronização da beleza, por exemplo".

O objetivo principal desta pesquisa foi o de analisar a forma como o corpo feminino é discursivizado nas obras de arte de lambe-lambe que são compartilhadas em rede. Através das sequencias discursivas, nos propusemos a compreender a inscrição de diferentes modos de significar o corpo da mulher, seja por este ser colocado enquanto um corpo que é ainda hoje abusado e erotizado em sociedade, seja por denunciar a imposição ao corpo feminino de padrões estéticos. Assim, as obras apontam para sentidos de um chamado ao sujeito-mulher ao processo de re-subjetivação. Como objetivos específicos, foram considerados dois pontos: a) compreender de que modo as configurações do digital determinam e dão corpo a relação dos sujeitos com os sentidos sobre o corpo feminino nas obras de lambe-lambe que são compartilhas em rede; b) analisar os efeitos de sentido que emergem sobre o corpo feminino inscrito na arte do lambe-lambe.

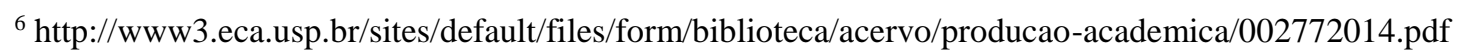

${ }^{7} \mathrm{https}$ ://catracalivre.com.br/cidadania/projeto-espalha-cartazes-feministas-por-sp-para-empoderar-as-mulheres/
} 
Os perfis do Instagram foram escolhidos por serem um espaço de intensa circulação de sentidos sobre feminino, sendo este um movimento ainda atual em nossa sociedade. Para realização dessa pesquisa, foi acessado um número de perfis considerável, todos brasileiros, de língua portuguesa, pertencentes a mulheres, com questões sobre o feminino e os sentidos sobre o corpo da mulher em nossa contemporaneidade, compostos por obras de arte de lambelambe e de livre acesso ao seu conteúdo.

É importante considerar que, quando articulamos por corpo feminino, não estamos abarcando às discussões de gênero. Ou seja, estamos no referindo ao corpo feminino de uma mulher, individuo cisgênero. Isso ocorreu pois, os materiais colhidos, partiam da autoria de mulheres e grupos de mulheres identificadas como cisgêneras.

Além deste capítulo introdutório, este trabalho ainda contém outros cinco, sendo três teóricos, um composto por nossas análises e um último com nossas considerações finais. No segundo capítulo, buscamos levantar os conceitos teóricos e analíticos utilizados nesta dissertação, tendo como base conceitual a Análise de Discurso de filiação francesa (doravante AD). Para isso, levantamos historicamente o modo como a análise do discurso constituiu-se como ciência e como os objetivos dessa pesquisa foram trabalhados a partir desta abordagem; também mobilizamos os conceitos teóricos da $\mathrm{AD}$ que foram utilizados no decorrer desta pesquisa.

No terceiro capítulo, buscamos tentar compreender de que modo as configurações do digital determinam e dão corpo à relação dos sujeitos com os sentidos sobre o corpo feminino nas obras de lambe-lambe que circulam nos perfis do Instagram que nos propomos analisar. Assim, buscamos analisar a relação entre rua e rede, tomando-a enquanto uma metonímia do espaço público, marcada por movimentos de sentido entre sujeitos e grupos sociais

No quarto capítulo, demos enfoque para a discussão e descrição da metodologia utilizada nessa pesquisa, abordando desde o local onde se encontra a metodologia da Análise de Discurso dentre as metodologias de pesquisa, até o modo como se deu a construção do nosso corpus de pesquisa, o modo como foram selecionados os perfis a serem investigados e a apresentação da metodologia da $\mathrm{AD}$, em suas particularidades e delineamentos teóricos e metodológicos.

As análises compõem o nosso quinto capítulo. Elas estão organizadas por entradas discursivas divididas em três momentos, compondo um total de 18 recortes provenientes de dois perfis do Instagram. O primeiro momento comporta redes de sentido que nos dizem acerca de uma idealização do corpo e da beleza feminina a qual se faz presente na mídia, quer digital ou não, levando em conta os sentidos que se materializam nestas obras. O segundo 
leva-nos a ler gestos discursivos que realizam um chamado à subjetividade do ser mulher, tendo em vista as questões nele envolvidas, tais como o desejo de ser e de (se) amar. Por último, nos debruçamos sobre materialidades cujos sentidos se entrelaçam num corpo que circula entre o público e o privado.

Por fim, no último capítulo estão expostas as nossas considerações finais, onde foram levantados, retomados e discutidos os pontos trabalhados durante toda a nossa pesquisa, apontados os limites da pesquisa e dados alguns norteamentos pra a produção de novas investigações. 


\section{A ANÁlISE DO DISCURSO DE LINHA FRANCESA E SEUS CONCEITOS FUNDAMENTAIS}

Figura 5 - Obra da artista visual brasileira Anarkia Boladona

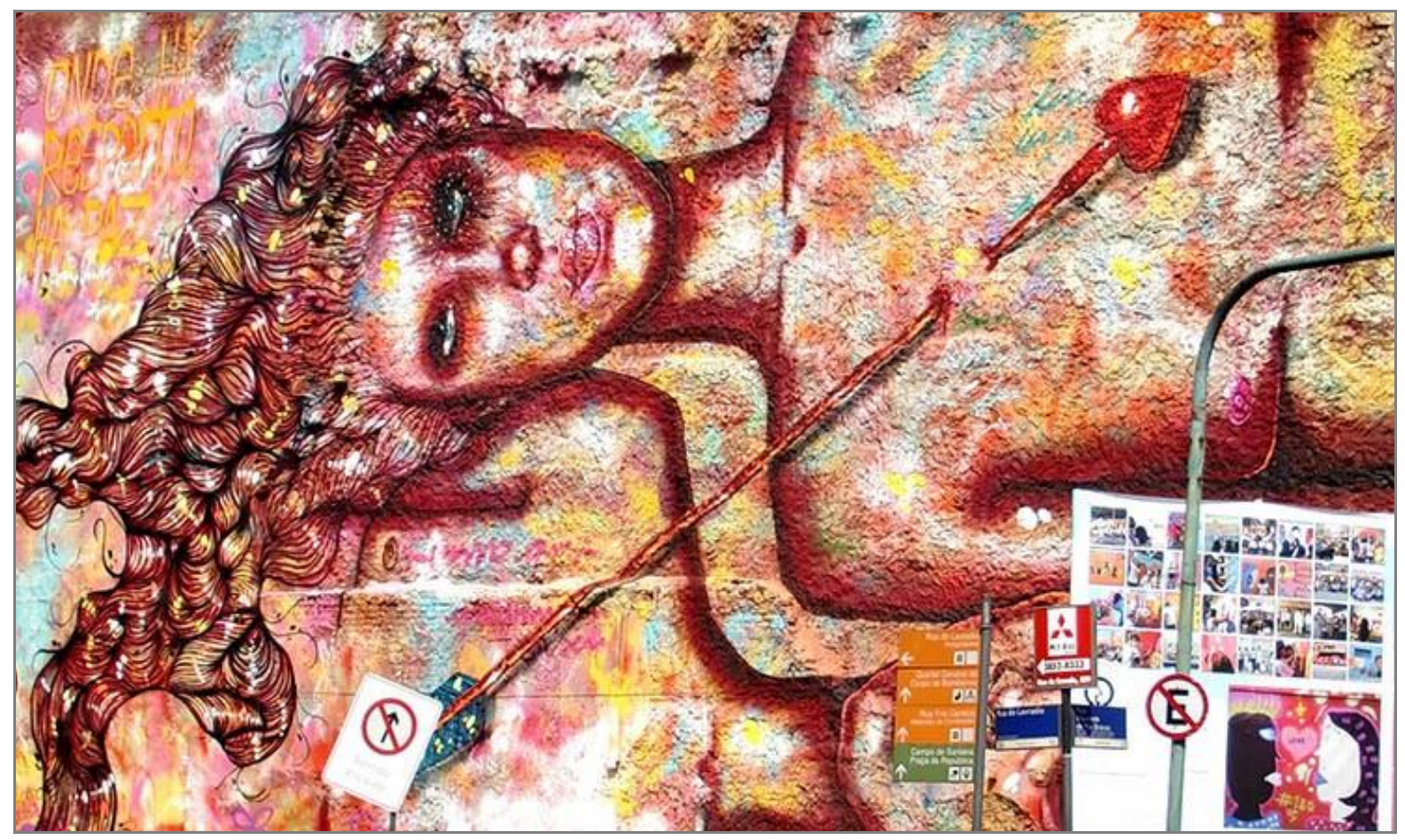

Fonte: http://memorialdademocracia.com.br/card/a-arte-engajada-de-anarkia-boladona

Nas duas faces de Eva

A bela e a fera

Um certo sorriso de quem nada quer

Sexo frágil

Não foge à luta

E nem só de cama vive a mulher

Por isso não provoque

É cor de rosa choque

Não provoque.

(Rita Lee, "Cor de rosa choque") 
O embasamento teórico e metodológico desta dissertação é o da Análise de Discurso de filiação francesa (ou $\mathrm{AD}$, como já apontado acima), cujo percurso teórico será traçado no presente capítulo. Para isso, apresentaremos os conceitos discursivos mobilizados e a forma como se realizou o trabalho interpretativo do sujeito, do sentido e da sociedade na posição de analista do discurso. Além disso, incluímos uma reflexão a respeito do processo de constituição histórica da $\mathrm{AD}$, uma vez que a história não é passível de ser ignorada, visto que ela constitui o discurso, a língua (Leandro-Ferreira, 2000).

A fim de organizar nossa reflexão, subdividimos este capítulo em duas seções: 2.1) onde refletimos sobre o modo como a análise do discurso constituiu-se como ciência e o modo como os objetivos dessa pesquisa foram trabalhados a partir desse olhar teórico e analítico e 2.2) onde mobilizamos os conceitos teóricos da $\mathrm{AD}$ que foram utilizados no decorrer desta pesquisa.

\subsection{A AD como ciência e a relação dessa teoria com os objetivos dessa pesquisa}

A AD surgiu em meados dos anos 1960, na França, em um período de alterações e transformações no campo político, social e, por consequência, científico. Conforme LeandroFerreira (2010), as ciências humanas sofreram grandes modificações influenciadas pelas mudanças político-sociais na época, sendo o maio de 1968 um momento importante da história francesa, o auge dessas transformações. Esse período tão importante caracterizou-se por protestos de estudantes de universidades francesas acerca de inúmeras pautas, entre elas, a "liberdade" (de pensamento, de expressão), a defesa dos direitos das minorias (trabalhadores, mulheres, homossexuais, não-brancos etc.) e a reforma do ensino nas universidades. Todas essas pautas eram correspondentes com a postura de desaprovação de muitos pensadores, entre eles, Pêcheux, criador da $\mathrm{AD}$, que propôs um outro olhar sobre a super-estrutura da sociedade, ou seja, seus aspectos histórico-culturais, em contraste com seus aspectos estruturais (os meios de produção), conforme apontado por Karl Marx .

O auge do estruturalismo na França ocorreu nesse período e nesse contexto histórico. Em seu cerne, residem as bases de reflexões de grande parte dos intelectuais da época que realizavam uma espécie de "apagamento" do sujeito de seus estudos, defendendo, assim, ser importante "normatizar o sujeito, já que era visto como o elemento suscetível de perturbar a análise do objeto científico, que deveria responder a uma língua objetivada, padronizada" (Leandro-Ferreira, 2010, p. 19). Nesse sentido, poderia se abolir o que viesse a abalar as 
evidências e os padrões fixos, assegurando à comunidade científica uma "falsa" sensação de estabilidade.

Michel Pêcheux, idealizador da AD, cria, então, uma teoria que contribuiu para uma mudança de paradigma nos estudos da língua, rompendo com o caráter imanentista do estruturalismo época, e trazendo a perspectiva da história, do social e da ideologia na produção discursiva para as reflexões da época, teorizando, assim, que o indivíduo está sujeito à linguagem, aos equívocos e à opacidade da língua. Isso alerta a comunidade científica de que não há neutralidade nem mesmo no uso dos signos usados cotidianamente e de que a entrada no simbólico é irremediável e permanente a todos os sujeitos e de que estamos a todo momento comprometidos com os sentidos e o político. Com isso, segundo Leandro-Ferreira (2011), Pêcheux rompe com as seguintes concepções: de que o homem cartesiano é a origem única de seus dizeres e de seus sentidos; da compreensão da história sem levar em conta as suas contradições e momentos de divergências resultantes de sua constituição e o fato de a noção de língua estar ancorada em uma ilusão de transparência, como se essa fosse capaz de dizer tudo, ser estável e transparente.

Desenvolvida a partir de três domínios disciplinares que fazem ruptura com o século XIX: a Linguística (estatuto científico da língua), o Marxismo (materialismo históricodialético) e a Psicanálise (subjetividade), a Análise do Discurso procura mostrar que a relação entre linguagem/pensamento/mundo não é única. Conforme afirma Orlandi (2007), foi a partir do legado do materialismo histórico que a AD nos mostra que a história tem seu real afetado pelo simbólico e através da linguística cuja língua tem sua ordem própria. Pela Psicanálise, a AD nos aponta que o sujeito é descentrado, pois é afetado pelo real da língua, ou seja, não é origem de seu dizer e que é também pelo real da história que um sujeito se constitui, não tendo o controle sob o modo como ela irá, ou não, afetá-lo. Logo, o sujeito discursivo opera pelo inconsciente e, também, pela ideologia.

No entanto, é importante salientar que, para a $\mathrm{AD}$, a concepção de discurso não se reduz ao objeto da Linguística e, também, não é integrada a teoria Marxista, nem tampouco corresponde à teoria Psicanalítica, mas sim "interroga a Linguística pela historicidade que ela deixa de lado, questiona o Materialismo perguntando pelo simbólico e se demarca na Psicanálise pelo modo como, considerando a historicidade, trabalha a ideologia como materialmente relacionada ao inconsciente sem ser absorvida por ele" (Orlandi, 2007, p. 20).

Em 1969, Pêcheux escreve sua obra intitulada "Análise Automática do Discurso", marcando a criação de um aparato teórico metodológico para pensar o discurso enquanto uma “máquina discursiva". Tal maquinaria contribuiu, para o autor, como um "laboratório de uma 
teoria do discurso ainda por vir" (Maldidier, 2003, p. 19). Nessa obra, foi possível que o autor questionasse conceitos que se encontravam já estabilizados/estabelecidos na academia: como o de texto, sentido e leitura. Com isso, Pêcheux estabelece e inaugura uma nova teoria que tem como seu objeto o discurso em suas condições de produção. Segundo Maldidier (2003, p. 21), esta obra inicial marca-se:

[...] enquanto teoria geral da produção dos efeitos de sentidos, que não será nem o substituto de uma teoria da ideologia nem o de uma teoria geral da produção dos efeitos de sentidos, que não será nem o substituto de uma teoria da ideologia nem o de uma teoria do inconsciente, mas poderá intervir no campo destas teorias (texto I).

Nesse contexto, a AD surge, então, como uma subárea dos estudos linguísticos inovadora e insurgente, já que, para ela, a linguagem tem potencial de causar deslizamentos que nem sempre permitem generalizações ou instituições identificáveis, podendo, desse modo, surgir sentidos inesperados que podem funcionar como óbvios para o sujeito que os enunciou, mas não tanto para outros. Para essa disciplina, os enunciados:

[...] surgem na relação com as práticas sócio-históricas. Não se trata de um indivíduo isolado usando a língua, inventando enunciados antes inexistentes. É na historicidade, e, na história enquanto modo de produzir sentidos, que se dá o aparecimento de um (ou vários) enunciado(s) constituindo o acontecimento sócio-histórico. (Mariani, 1996, p. 92).

É dessa forma, e é a partir dessa divergência com o pensamento vigente na época, que Pêcheux (1990) tece a Análise de Discurso apoiando-se na interface existente entre Linguística e a História, interconexão essa que: "representa a possibilidade de ler no discurso textual os traços da memória histórica tomada no jogo da língua" (Maldidier, 2003, p. 90). A $\mathrm{AD}$ não é, então, somente uma teoria da linguagem com um método de interpretação, é, sobretudo, um pensamento materialista, não-metafísico, sobre ideologia que leva em consideração a materialidade do discurso, e se coloca a compreender a relação entre um dizer, a história, a linguagem e o inconsciente.

Segundo Orlandi (2002), a AD funciona a partir de uma condição de entremeio, em que não há um imperativo categórico, dogmático, de um só lugar de filiação, sendo uma disciplina que funciona a partir de espaços relacionais entre saberes. Para a autora, podemos pensar essa noção diferente do conceito de intervalo, já que, a ideia de entremeio se refere a:

[...] espaços habitados simultaneamente, estabelecidos por relações contraditórias entre teorias. Relações em que não faltam pressões, processos de inclusão e de exclusão, hierarquização e legitimação, apagamentos, ou seja, relações de sentidos, mas também relações de força, na medida em que a forma sujeito histórica, que é a nossa, inclui, ou melhor, funciona pelo conhecimento, e por sua relação com o Poder. (Orlandi, 2002, p. 21). 
Contudo, a noção de entremeio não é pensada de forma restrita em relação à $\mathrm{AD}$ e às demais disciplinas, como já foi colocado, mas ao próprio processo de análise discursiva, pois:

Temos o tipo de análise, os conceitos, nossa escrita. Se levarmos às últimas consequências a noção de entremeio e o modo como funciona o interdiscurso, podemos concluir que não estamos fixados em lugar algum, estando no entremeio. Estamos suspensos, no plural, no movimento, na polissemia. (Orlandi, 2012, p. 53).

Com isso, para este trabalho, nos propomos investigar a relação de entremeio existente na relação entre a rede e a rua, com e através da escrita das obras de lambe-lambe que são compartilhadas em rede, sendo elas não somente uma tecnologia de linguagem, mas também um processo social, cuja sustentação não opera por uma relação do Estado com o espaço, regulando e administrando sentidos, mas dentro de uma condição singular de produção e circulação de dizeres, e a partir da maneira como o sujeito se inscreve discursivamente, (r)existindo a sentidos estabilizados de um discurso machista sobre a mulher e, assim, (re)existindo, depositando outros sentidos sobre o feminino e seu corpo. Ou seja, a partir da relação entre linguagem e ideologia na materialidade digital.

Trabalharemos, no capítulo a seguir, acerca dessa relação de entremeio entre rua e rede, como também acerca da materialidade digital e o como ela apresenta em si uma gama de possibilidades de formas de circular, e discursivizar, sentidos, especialmente por considerarmos os modos como a tecnologia, hoje, é praticada numa historicidade que perpassa os espaços, físico e digital, sendo capaz de romper com processos de significação e de constituição de sujeitos e sentidos socialmente estabilizados.

A partir disso, desenvolvemos a articulação entre materialidades pelas quais não se considera uma "separação estanque entre a linguagem e sua exterioridade constitutiva, [pela qual não se separa] linguagem e sociedade na história" (Orlandi, 1996, p. 25), isto ocorre nesta pesquisa, principalmente por, como bem pontua Dias (2018), rede e rua serem afetadas hoje pelo discurso digital e produzirem sentidos para um trabalho que pode ser pensado lado a lado, sendo este fato uma potência importante para analisarmos o político na língua. Portanto, uma materialidade se encontra na ordem da existência de um alicerce material, que existe por efeito de uma produção de sentidos. No caso dessa pesquisa, trabalhamos com o que afeta, de modo imprescindível, a formação-social na atualidade: a tecnologia.

Pensar como os processos de linguagem estão presentes em nossa sociedade e observar a produção de sentidos em nosso cotidiano têm gerado pesquisas interessantes e promovido discussões férteis entre pesquisadores do discurso. A Análise Discursiva (da posição do analista) se constitui como um gesto de interpretação, e partimos do gesto de 
produzir e circular obras de arte de lambe-lambe para compreender o funcionamento discursivo dessas obras em rede.

Dito isso, é preciso reconhecer que uma ciência, na realidade, traz já na sua própria constituição os rumos e os riscos a que se expõe. Não é diferente com a análise de discurso: os rumos e riscos estão no fato de que se caracteriza como uma teoria de entremeio (Orlandi, 2012, p. 42).

De acordo com Orlandi (2012), estamos diante de um novo momento na AD, em que novas questões e problemas são postos para os analistas de discurso e que propiciam (exigem) novos investimentos teóricos. Para a autora, a AD passa por uma 'virada' que exige a reflexão de três questões centrais: conjuntura teórica; conjuntura histórica e mobilização analítica; para pensar as transformações da/na contemporaneidade, pontos que exigem atenção e apresentam oportunidades de trabalho para os analistas do discurso. Segundo a autora, o sujeito é afetado pelas condições do capitalismo, que, por sua vez, afeta o processo de constituição e inscrição do sujeito em seu discurso. Com isso, cabe ao analista do discurso "compreender as novas formas de assujeitamento" (Orlandi, 2012, p. 47), e esse é o desafio imposto aos que trabalham com a AD hoje. Para a teoria discursiva, a linguagem promove deslizamentos de sentidos que nem sempre permitem generalizações ou sentidos identificáveis. Segundo Mariani (1996, p. 92):

\footnotetext{
Os enunciados, portanto, surgem na relação com as práticas sócio-históricas. Não se trata de um indivíduo isolado usando a língua, inventando enunciados antes inexistentes. É na historicidade, i.e., na história enquanto modo de produzir sentidos, que se dá o aparecimento de um (ou vários) enunciado(s) constituindo o acontecimento sócio-histórico.
}

Sendo assim, na ordem da língua e nas relações entre sujeito e sociedade, um discurso está sujeito a tensões e conflitos, já que o ato de realizar um trabalho de Análise de Discurso, corresponde a compreender que: "[...] tomar a palavra é um ato social com todas as suas implicações: conflitos, reconhecimentos, relações de poder, constituição de identidade, etc. [...]" (Orlandi, 1988, p. 17) pois todo falante ocupa um lugar na sociedade, e isso faz parte da significação.

Tais características foram decisivas para amparar os objetivos dessa pesquisa, que se propõe analisar a forma como o corpo feminino é discursivizado nas obras de arte de lambelambe que são compartilhadas em rede. Eleger a AD como ciência de investigação para essa pesquisa nos possibilitou olhar para os deslizamentos, furos e a incompletude da língua como parte do processo discursivo. Também permitiu considerarmos a tensão que se constitui nas relações sociais e analisar como essa se materializa na língua e, por consequência, nas redes. Assim, a fim de refletirmos sobre a existência de sentidos outros (a serem) regularizados no seio social sobre o feminino, trabalhamos com materiais publicados em perfis do Instagram 
das seguintes contas: (@projeto.encontrarte e @lela.brandao), considerando-os como nosso corpus de pesquisa. Ocupamo-nos de analisar a forma como os sentidos se materializam nas obras dessas contas e o efeito discursivo que essas estabelecem.

Nesse caminho, como já dito anteriormente, nosso objetivo principal é analisar a forma como a mulher e seu corpo são discursivizados em rede por essas contas, permitindo, também, por meio das sequencias discursivas e da teoria discursiva: a) compreender de que modo as configurações do digital determinam e dão corpo a relação dos sujeitos com os sentidos sobre o corpo feminino nas obras de lambe-lambe que circulam no espaço digital; b) analisar os efeitos de sentido que emergem sobre o corpo feminino inscrito na arte do lambelambe.

É importante colocar que o movimento produzido no digital nos interessa justamente pelas suas condições de produção, tais como: a velocidade, o alto alcance e a fragmentação, produzindo outros modos de estabilização de sentidos, que podem ser pensados nessa pesquisa. Assim, fundamentamos nossos objetivos pela necessidade imediata de refletirmos sobre o modo como o espaço digital possibilita abordar o sujeito mulher e seu corpo hoje. Em virtude disso, esta pesquisa não se centra no indivíduo, sendo um termo incompatível com o método discursivo, mas no sujeito discursivo, já que nesta perspectiva que adotamos tem por foco de investigação o modo como se dá a inscrição da língua na história, a posição discursiva de um sujeito no social quando irrompe o seu dizer e o atravessamento do processo de interpelação ideológica em seu discurso.

$\mathrm{Na} \mathrm{AD}$, concepção discursiva de sujeito refere-se a uma posição ocupada a partir da história e da ideologia pelas quais ele foi interpelado, para que a partir da sua posição irrompa a produção de sentidos diversos. Logo, é a partir da linguagem que o sujeito se constitui, é, também, nela que ele deixa as marcas desse processo ideológico.

A Análise de Discurso não se ancora no

[...] extremo da pura subjetividade, do 'achar' que é rebatido por um 'achar' contrário, sem procedimentos concretos que possam solidificar uma análise, nem no outro extremo dos modelos prontos, definidos anteriormente a seus objetos, que podem nos levar a uma análise conteudística, onde o que temos a dizer serve apenas para comprovar uma conclusão pré-estabelecida (Lagazzi, 1988, p. $51)$.

Assim, analisar as obras artísticas de lambe-lambe pelo viés da $\mathrm{AD}$ não consiste em apenas observar um padrão pré-estabelecido para o pesquisador, mas de descrever as práticas discursivas que permitem que determinados sentidos irrompam em determinadas condições de produção. Identificamos, desse modo, como justificativa para esta dissertação, a importância em se refletir sobre o modo como estas contas surgem como uma atualização do discurso 
capaz de estabelecer a movimentação de sentidos pré-estabelecidos, a partir de uma desidentificação com um dizer dominante que inscreve a mulher e seu corpo a partir de uma posição machista e patriarcal. Discutimos o modo como os sentidos, atrelados a novas formas de ser e estar em sociedade estão postos em jogo nos espaços destas contas ao abordar o uso da tecnologia para atualizar sentidos acerca da mulher, o público e a liberdade de seu corpo.

Ao trabalharmos com um objeto, lambe-lambe, que é posto tanto na rua como na rede, não nos colocamos entre um e outro (rua e rede), mas em um entremeio, em um entre áreas, como afirma Orlandi (1996, p. 24) no seguinte excerto: "aproveitando a outra disciplina ao revés", interrogando-a sobre aquilo que é deixado de fora de seu campo constitutivo e que nega a existência possível de um outro "objeto", o discurso, ou "outro discurso". Nesse contexto, não pensamos rua e rede como espaços separados, mas como um espaço comum, que se co(n)funde, na medida em que rede e rua são afetadas pelo discurso digital, produzindo sentidos para um trabalho que está lado a lado, sendo esta possibilidade o elemento que faz ressurgir a potência do político.

Também temos por necessidade localizar o leitor quanto à noção de corpo dentro da perspectiva da análise discursiva que nos propomos utilizar, já que objetivamos observar de que forma o corpo da mulher é (res)significado nas obras de arte de lambe-lambe. Para a AD, o conceito de corpo não equivale ao da medicina e ao biológico, nem ao de sua realidade empírica, naturalizado. Para essa disciplina, a partir do momento em que um sujeito entra na linguagem, o corpo é desnaturalizado e passa a ser feito, e, efeito de linguagem, atravessado por sentidos e determinado pela ideologia. Afinal, segundo Leandro-Ferreira (2013, p 77) o "corpo é tanto uma linguagem, como uma forma de subjetivação e, por isso mesmo, tem relação estreita com o discurso". Sendo assim, e segundo a essa autora, para a AD, o corpo surge estreitamente ligado a novas formas de assujeitamento, sendo, então, associado à noção de ideologia tida pela AD. O corpo para a AD:

\footnotetext{
[...] comparece como dispositivo de visualização, como modo de ver o sujeito, suas circunstâncias, sua historicidade e a cultura que o constituem. Trata-se do corpo que olha e que se expõe ao olhar do outro. O corpo intangível e o corpo que se deixa manipular. O corpo como lugar do visível e do invisível. (Leandro-Ferreira, 2003, p. 78).
}

Nesse processo, ao pensarmos a noção de corpo enquanto um corpo discursivo, propusemo-nos a analisar nesta pesquisa a forma como o corpo da mulher é discursivizado nas obras de lambe-lambe compartilhadas em rede, a fim de verificar quais os sentidos são postos em circulação e como o corpo desses sujeitos são textualizados e significados nas obras. É importante salientar que as proprietárias das contas e das obras são mulheres, sendo 
tal item mais bem clarificado no capítulo metodológico, mas que se torna para nós importante, pois:

Os sujeitos textualizam seu corpo pela maneira mesma como estão nele significados, e se deslocam na sociedade e na história: corpos segregados, corpos legítimos, corpos tatuados. Corpos integrados. Corpos fora do lugar. O comum, o normatizado, o hegemônico. O corpo do rico, o corpo do pobre. Temos observado as distintas formas como o corpo significa, se textualiza, circula pela existência de significantes distintos, sendo o homem, um sujeito que interpreta e é interpretado (Orlandi, 2012, p. 87).

Ao trabalharmos com o corpo textualizado nas obras de lambe-lambe, estamos trabalhando com um dizer do/sobre o corpo que só é possível a partir da língua que produz efeitos de virada com sentidos biologizantes, usualmente regularizados para o corpo. Assim, nessas obras, não trabalharemos com sentidos sobre o funcionamento biológico do corpo, mas com o funcionamento no corpo desde de uma determinada condição sócio, histórica e ideológica. Com as obras que analisamos, identificamos sentidos de denúncia a uma sociedade que, ainda hoje, violenta a mulher ao colocar seu corpo em posição de uso e a apropriação pelo outro, havendo, assim, nas obras, uma denúncia para um silenciamento do desejo, ou não, da mulher perante o uso de seu corpo por um Outro, quer seja para um uso sexual, e o objetificando como um objeto para proporcionar prazer, que seja para a imposição de um corpo normatizado

Observamos nos lambe-lambes; diferentes modos de considerar o corpo feminino, evidenciando sentidos a respeito do abuso e da imposição de padrões físicos, devido às obras apresentarem sentidos acerca de uma queixa ao modo como o corpo feminino é discursivizado em sociedade, enquanto um corpo que deve se apresentar perfeito, intimamente ligado a uma beleza extraordinária, naturalizada, um corpo projeto, idealizado, que se impõe sobre as condições de existência do sujeito, afetando a forma como o corpo significa e é significado em sociedade. Também se percebeu o corpo da mulher posto tal como historicamente o da meretriz, um corpo sujeito a violações.

A partir dessas reflexões que realizamos até então, consideramos ser necessária a elucidação do cerne teórico mobilizado para as análises e reflexões dos recortes dessa pesquisa. Tarefa essa que iremos realizar na próxima seção.

\subsection{O tecer de uma teoria e a sua importância para a compreensão de um entrelaçar de sentidos sobre a mulher no Post(e)}

Como já mencionamos, propomo-nos, aqui, retomar os conceitos fundamentais da Análise do Discurso Francesa que possuem grande valor para o presente trabalho: Discurso, 
Sujeito, Formação Discursiva, Ideologia e Memória. Como também retomar a teorização dos processos de formulação, constituição e circulação do discurso para a AD. É importante colocar que a disciplina fundada por Michel Pêcheux nos auxiliou em nossa compreensão sobre o modo como as determinações sócio-histórica e ideológicas atuam na produção dos dizeres (e dos sentidos) sobre o feminino.

Conforme Maldidier (2003, p. 21), o discurso, para Pêcheux, "deve ser tomado como um conceito que não se confunde nem com o discurso empírico, sustentado por um sujeito, nem com o texto, um conceito que estoura qualquer concepção comunicacional da linguagem". Ou seja, o discurso, para a $\mathrm{AD}$, é tido como um efeito de sentidos entre interlocutores (Pêcheux, 1997), sendo, assim, um objeto que estabelece "um verdadeiro nó, lugar teórico onde se intricam questões sobre a língua, a história e o sujeito" (Maldidier, 2003, p. 15). Este nó, extremamente importante para a $\mathrm{AD}$, ocorre exatamente pela constituição desta teoria ter sido estabelecida a partir de uma relação de entremeio entre teorias. Assim que, ao trabalhar a relação entre linguagem, ideologia e inconsciente, estamos olhando para os objetos, não procurando neles um sentido em si, mas em sua relação com a língua, a história e o sujeito. Segundo Orlandi (1998, p. 28),

\footnotetext{
A AD se interessa pela linguagem tomada como prática: mediação, trabalho simbólico, e não como instrumento de comunicação. É ação que transforma, que constitui identidades. Ao falar, ao significar, eu me significo. Aí retorna a noção de ideologia, junto à ideia de movimento. Do ponto de vista discursivo, sujeito e sentidos não podem ser tratados como já existentes em si, como a priori, pois é pelo efeito ideológico elementar que funciona, como se eles já estivessem sempre lá.
}

Assim, ao aproximarmo-nos da questão dos gestos de leitura e interpretação das obras que nos propomos analisar, é impossível não nos atermos ao conceito de discurso que, neste trabalho, será compreendido como um sentido formulado a partir das relações sociais em sua permanente tentativa de dizer sentidos sobre a mulher sob uma ótica outra da socialmente estabilizada. É importante salientar que não é interesse do analista do discurso se colocar como especialista da interpretação, buscando encontrar um sentido total, mas sim a permissão para evidenciar a opacidade da língua, entendendo que os sentidos são plurais e não óbvios e que existe uma relação desta com a história e os sujeitos. Para a $\mathrm{AD}$, o discurso e a língua são estruturas dispersas, havendo uma ilusão de controle e naturalização dos sentidos, afetando a discursividade que se estabelece, como se o sujeito e os sentidos não pudessem ser apresentados de outra maneira, estabelecendo uma naturalização tanto de um como de outro, trazendo, então, os sentidos para, como bem apresentado por Pêcheux (2006, p. 50), uma "lógica do ou...ou" e não para a "lógica do e....e". Ou seja, ou o sentido é um, ou ele é outro. Ele é naturalizado e transparente. Como se não houvesse a possibilidade de dentro de um 
discurso haver outros sentidos. Essa ilusão é muito trabalhada na teoria da $\mathrm{AD}$, sendo, então, o que a diferencia de outras teorias dentro da linguística, já que, a partir dela, podemos olhar para o discurso de forma não transparente. Assim, a posição do analista vem evidenciar a nãotransparência da linguagem, sendo que para a $\mathrm{AD}$ “interpretar não é atribuir sentido, mas expor-se a opacidade do texto, ou seja, é explicitar como um objeto simbólico produz sentidos" (Orlandi, 2010).

Buscamos compreender os efeitos de sentido demarcados pelas relações sociais, a partir de um lugar de formular outros sentidos sobre o corpo da mulher, o Instagram. Logo, como afirmamos, o sentido das palavras nessa perspectiva discursiva não está totalmente atrelado a elas, pelo contrário. Acreditamos, como analistas do discurso, que o sentido está constantemente no "entremeio", sendo possível de ser analisado a partir dos lugares de inscrição dos sujeitos, que se inscrevem em diferentes formações ideológicas. Ademais, as palavras, nesse jogo discursivo entre a transparência e a opacidade, estabelecem sentidos que não são literais e que não existem em si mesmos, mas que são determinados pelas posiçõessujeitos ocupadas no processo sócio-histórico, o palco da (re)produção das palavras no qual o sujeito está intrinsecamente ligado para fazer circular seus dizeres.

É, pois, no discurso que ocorre o processo de inscrição do sujeito (Pêcheux, 1997), emergido da relação com a linguagem, a história, e a ideologia que permeiam seu dizer. Nas palavras de Maldidier (2003, p. 15),

\footnotetext{
O discurso me parece, em Michel Pêcheux, um verdadeiro nó. Não é jamais um objeto primeiro ou empírico. É o lugar teórico em que se intricam, literalmente, todas as suas grandes questões sobre a língua, a história, o sujeito. A originalidade da aventura teórica do discurso prende-se ao fato que ela se desenvolve no duplo plano do pensamento teórico e do dispositivo da análise de discurso, que é seu instrumento.
}

Dessa dupla determinação, surge o nascimento de uma "teoria geral da produção dos efeitos de sentidos" (Maldidier, 2003, p. 21), tendo, então, como o seu objeto de estudo o discurso compreendido como "efeito de sentidos" (Pêcheux, 1975), na medida em que nele história, sujeito, e ideologia coabitam, possibilitando uma teoria que se concebe em prática dos e pelos sujeitos. Pautados por esta imbricação entre teoria e prática analítica, proposta por Pêcheux (1975) no estabelecimento da disciplina, propusemo-nos pensar o sujeito, e seu corpo, discursivizado nos lambe-lambes, em especial no que concerne ao entrelaçamento dos sentidos sobre a mulher no Post(e).

Pensamos nesta fusão entre post e poste por não pensá-los enquanto instâncias separas, mas como materialidades. independentes - on e o off-line - que se atravessam por um espaço “em-comum", o público, no qual rua e rede se co(n)fundem, na medida em que o discurso se 
materializa e nos posts na rede digital. Assim, o Post(e) se materializa como o ponto de entrelaçamento destes espaços em-comum.

Neste percurso que aqui trilhamos, irrompe um sujeito que se movimenta, desloca, resiste e rompe com os sentidos no decorrer do processo discursivo de significar a mulher e seu corpo em sociedade. Ressalta-se a escolha da AD em pensar o sujeito a partir do seu momento histórico nos tempos da política neoliberal e da globalização. "O sujeito não tem como controlar os sentidos como um todo, pois eles podem sempre vir-a-ser outros na relação com o outro, nas variações do tempo e do espaço em que ocorrem as enunciações" (Patti, 2012, p. 18), ou seja, existem posições-sujeito no discurso por onde se inscrevem relações históricas e de produção que constituem o discurso e o sujeito. Deste modo, sob o efeito de uma evidência de sentidos, inúmeros dizeres sobre a mulher e seu corpo são postos em circulação em nossa sociedade, promovendo, com isso, a constituição de um imaginário de corpo regularizado em nossa formação social. Assim, o funcionamento de sentidos regularizados, de uma memória discursiva sobre o corpo da mulher pode ser posto em cheque nas obras, já que ao pensarmos o corpus que nos dedicamos a estudar, lidamos com um veículo que visa romper dizeres/sentidos sobre o corpo da mulher. Então, quais sentidos se inscrevem nos posts? De que sujeito-mulher eles falam? Qual o imaginário de mulher, e de corpo, se manifesta nas obras?

Tais questões são de extrema importância, haja visto que mesmo com os discursos sobre as mulheres atravessando os tempos, desregularizando determinados sentidos e práticas, em especial no que concerne ao seu corpo na contemporaneidade, é possível perceber um movimento ativo nas redes, deslocando o epicentro, segundo Araújo (2016), dessas discussões da academia (de um dizer teórico sobre) ou de partidos políticos, para outro lugar, o digital.

Vivemos a égide do sistema capitalista que, como bem pontua Sanches (2018), apropria sentidos às nossas práticas sociais, fazendo com que nossos processos de subjetivação funcionem a partir de uma lógica de mercado. Os movimentos de sentido que nos propomos a analisar entram, então, na contramão do movimento capitalista. Conforme Orlandi (2007, p. 15): “mesmo havendo um deslocamento nas formas como o capitalismo se pratica e estabelece suas relações de poder, ainda assim, continuamos no domínio ideológico do capitalismo", para a AD, "o indivíduo é interpelado em sujeito pela ideologia para que produza o dizer" (Orlandi, 2007, p. 46).

Considerando a ideologia enquanto uma "prática significante", que "aparece como efeito da relação necessária do sujeito com a língua e com a história para que haja sentido" (Orlandi, 2007, p. 48), ao enunciarmos, estamos ocupando uma determinada posição no 
discurso, a qual é determinada pelas condições de produção sócio-históricas e ideológicas. Vemos, pois, as palavras do sujeito promovendo sentidos de acordo com o contexto da enunciação e da posição que ele ocupa para enunciar. Logo, é a ideologia dominante que convoca os sujeitos a ocuparem lugares pré-determinados na esfera social. Um sujeito, quando confere um gesto de resistência a uma disputa tensa de sentido, em que pese a sua (in)visibilidade no seio social, trava neste espaço, inevitavelmente, um gesto político na língua.

Podemos pensar que o objeto que nos colocamos a analisar é afetado pelo mesmo princípio, já que o sujeito que o produz é atravessado e constituído pelo discurso do mercado e da posse que se preocupa com um perfil a ser traçado de um ideal de mulher naturalizado pela ideologia dominante por meio de discursos e práticas inerentes à ordem vigente.

Althusser (1970), ao escrever sua teoria sobre os Aparelhos Ideológicos do Estado, desarticula a noção marxista de ideologia como sistema abstrato para concebê-la em seu funcionamento, isto é, na materialidade da língua. Conforme o estudioso afirma, os aparelhos ideológicos (AIE) são instituições distintas que atuam em concordância entre si, induzindo os sujeitos a pensarem/agirem de forma a satisfazer os desígnios das formações ideológicas vigentes com o objetivo de manter conjuntura e sustentação do poder (Althusser, 1970). Sob o efeito de evidência dos sentidos, a ideologia se materializa na linguagem e convoca os sujeitos discursivos a assumirem seus lugares pré-determinados ideologicamente no interior da esfera social.

Pêcheux (2009) retoma Althusser (1970) nesse ponto e pensa funcionamento da ideologia no discurso sob a forma de formações ideológicas que se materializam discursivamente, trazendo ao leitor os lugares onde os sujeitos se inscrevem ideologicamente em determinada esfera social. As obras de arte que analisamos vêm exatamente tocar esse discurso de mercado, confrontando-o, marcando que as mulheres não precisam atender a essa lógica, adequando seus corpos a todo momento dentro de um ideal posto por um mercado. Essas também pontuam o corpo da mulher não tomado como objeto de consumo, visto como objeto pelo outro para sua aquisição e posse.

Para compreender se há ou não a desnaturalização de dizeres sobre o corpo feminino, é necessário entender o modo como o sujeito se relaciona com a formação discursiva. Formação que se inscreve em uma determinada conjuntura sócio-histórica e que, em certa medida, regula dizeres acerca de um modo de ser mulher na contemporaneidade. Como já visto, o sujeito do discurso é aquele que, para falar e produzir sentidos, se submete a uma determinada formação discursiva, isto é, se submete àquilo que pode e deve ser dito a partir 
de uma dada posição e de uma certa conjuntura, sendo a FD a matriz de sentidos inerentes a uma determinada ideologia (Pêcheux, 1997).

Ou seja, o processo de "interpelação do indivíduo em sujeito de seu discurso se efetua pela identificação (do sujeito) com a formação discursiva que o domina (isto é, na qual ele é constituído como sujeito" (Pêcheux, 1997, p. 163). Assim, um sujeito discursivo não se apresenta em si mesmo, em sua essência, mas se inscreve a partir de determinada FD, identificando-se, a partir do lugar que ocupa nas relações de poder tramadas socialmente (Pêcheux, 2010 [1969]). Para melhor compreender o conceito de formações discursivas, é necessário compreender as formações ideológicas dentro das quais as formações discursivas estão inseridas. Para isso, é preciso ter em mente a estrutura social dada, assim como suas respectivas condições de produção.

Como bem apontam os estudos de Chaves (2015) e Sousa e Garcia (2015), tomando a nossa sociedade em sua historicidade, podemos perceber que esta condescendeu com certos discursos machistas contra a mulher e seu corpo. Segundo Sanches (2018) ao longo dos tempos, a padronização do corpo era (e ainda é) significada como fator de inclusão dos sujeitos, de forma a direcioná-los a determinadas práticas sociais. A partir desses estudos, podemos então perceber que o corpo branco, magro, jovem, considerado "belo" circulava e ainda circula com maior facilidade e "adequação" pelo meio social, enquanto um ideal pelas formações discursivas posta sobre como deve ser um corpo de mulher. Assim como a mulher cujo corpo manifestava-se como "recatado" e seguindo certo "pudor" imposto ideologicamente por uma sociedade patriarcal era visto (e ainda é) como um corpo não público, ou seja, um corpo que não era objeto de uma sociedade, de domínio público.

Destarte, partir de formações discursivas sobre um ideal de mulher, um padrão é posto em circulação em nossa sociedade. Segundo Orlandi (2007, p. 43):

[...] as formações discursivas representam no discurso as formações ideológicas. Desse modo, os sentidos sempre são determinados ideologicamente. Não há sentido que não o seja. Tudo que dizemos tem, pois, um traço ideológico em relação a outros traços ideológicos. E isso não está na essência das palavras, mas na discursividade, isto é, na maneira como, no discurso, a ideologia produz seus efeitos, materializando-se nele

As práticas dessas ideologias se materializam no discurso pelas formações discursivas, que possui uma materialidade histórica e social, que é produto das práticas sociais de cada sujeito. Dessa maneira, a interpretação é atravessada pelo processo de produção de sentidos que se estabelece em um verdadeiro jogo no qual se apresentam dois caminhos possíveis: marcados por sentidos dominantes, naturalizados pela ideologia, assim como por sentidos de 
resistência apontam no discurso social, realizando um movimento de fissura e oposição ao que é estabelecido e estabilizado.

Os sentidos sobre um ideal de mulher e de corpo são determinados ideologicamente e seus efeitos podem ser vistos materializados no discurso. De tal modo, o sujeito não é origem do que diz e nem livre para dizer o que bem entender, já que precisa situar seu dizer em uma determinada FD e não em outra, para assim atribuir-lhe sentido. Para Mussalim (2003, p. 133):

O sujeito passa a ser concebido como aquele que desempenha diferentes papéis de acordo com as várias posições que ocupa no espaço interdiscursivo. [...]. O sujeito apesar de desempenhar diversos papéis, não é totalmente livre; ele sofre as coerções da formação discursiva do interior da qual já enuncia, já que esta é regulada por uma formação ideológica. Em outras palavras, o sujeito do discurso ocupa um lugar de onde enuncia, e é este lugar, entendido como a representação de traços de determinado lugar social, [...] que determina o que ele pode ou não dizer a partir dali, ou seja, este sujeito, ocupando o lugar que ocupa no interior de uma formação social, é dominado por uma determinada formação ideológica que preestabelece as possibilidades de sentido de seu discurso.

Entendemos que essa representação de traços de determinado lugar social, de que nos diz Mussalim (2003), advém de sentidos historicamente naturalizados na sociedade a partir de uma memória. No entanto, segundo Pêcheux ([1983] 1999), p. 56), a memória não deve ser pensada enquanto um local onde o sentido é homogêneo, acumulado ao modo de um reservatório, mas como "um espaço móvel, de divisões de sentido, de deslocamentos, retomadas de conflitos e de regularização de sentidos". Isso porque a memória opera como um ponto de intersecção entre língua e história, possibilitando que os dizeres sejam resignificados, ou não, ao longo dos tempos. Dizeres/sentidos possíveis de serem retomados a partir do que Pêcheux (2009[1975], p. 149) denomina de um "todo complexo com dominante" das formações discursivas, o interdiscurso. Ao serem retomados, esses sentidos se inscrevem no jogo de forças constitutivo da ideologia, e inerente a todo dizer, tornando-se passíveis de se tornarem outros, a depender das posições que os sujeitos ocupam na/para a produção do dizer bem como das condições sócio-histórico-ideológicas em que estão envolvidos no momento da enunciação.

As obras de lambe-lambe, são um espaço de desdobramentos, polêmicas, contradiscursos. É pelo funcionamento do interdiscurso que contamos com os sentidos “evidentes” para a mulher e seu corpo em sua posição na sociedade. Ou seja, ao funcionar o interdiscurso, os sujeitos se inscrevem em dadas formações discursivas que fazem circular sentidos ao masculino e ao feminino vistos como os únicos sentidos possíveis.

Os sentidos postos em circulação quanto às mulheres, evidenciam a forma como a sociedade as vê, a partir de sua inscrição na história e no social. No movimento Marcha das Vadias, por exemplo, como bem coloca Chaves (2015), a terminologia "vadia" é 
(re)significada para se constituir um sentido diferente ao do saber popular, passando a ter um sentido de luta, separado do sentido ligado à vadiagem, à malandragem ou à prostituição.

\footnotetext{
A vadia da Marcha aparece como outra possibilidade de articulação discursiva, em que a memória opera tanto em esquecimento - pois, esburacou-se, perdeu o trajeto (do Crime de Vadiagem48) - quanto em disputa, pois sob o mesmo da materialidade da palavra vadia, ecoam determinações históricas de uma sociedade marcada por diferenças significativas na forma de conceber a presença de homens e mulheres no espaço público. (Chaves, 2015, p. 119).
}

As obras de lambe-lambe analisadas operam da mesma forma, desnaturalizando os sentidos em torno das denominações dadas às mulheres e a seu corpo, evidenciando a forma como a sociedade as vê, de acordo com sua inscrição na história. A este respeito, "vale lembrar que o sujeito e o sentido se constituem ao mesmo tempo, na articulação da língua com a história, em que entram o imaginário e a ideologia" (Orlandi, 2007, p. 99). Há, então, a inscrição de formações ideológicas em um discurso que “[...] em sua materialidade concreta, a instância ideológica existe sob a forma de formações ideológicas (referidas aos aparelhos ideológicos de Estado), e que, ao mesmo tempo, possuem um caráter 'regional' e comportam posições de classe [...]" (Pêcheux, 2009, p. 132).

As redes sociais são um espaço não só contraditório, por possibilitar a inscrição de diversos sentidos, mas também um lugar que mantém sua unidade e hegemonia, “[...] a unidade entre os diferentes Aparelhos Ideológicos de Estado está assegurada, geralmente de maneira contraditória, pela ideologia dominante, a da classe dominante" (Pêcheux, 2009, p. 133). Há, pois, em um discurso, o funcionamento "dissimulado" da ideologia em que:

[...] a relação de classes é dissimulada no funcionamento do aparelho de Estado pelo próprio mecanismo que a realiza, de modo que a sociedade, o Estado e os sujeitos de direito (supostamente livres e iguais em direito no modo de produção capitalista) são produzidos-reproduzidos como 'evidências naturais' (Pêcheux, 2009, p. 134).

Orlandi (2012) empreende uma reflexão crítica sobre a resistência do sujeito a determinados sentidos sócio-historicamente determinados, tomando-a como efeito das relações dissimétricas decorrentes das atuais formas de assujeitamento do capitalismo, em que a ideologia dominante falha e produz um resto; deste modo, o sujeito emerge teimando, insistindo em divergir para (r)existir. Sujeito do discurso que afeta e é afetado pelas condições de produção históricas atuais, sendo que a $\mathrm{AD}$ tem como premissa "um discurso [que] é sempre pronunciado a partir de condições de produção dadas" (Pêcheux, 1997, p. 75). A noção de condições de produção é um dos conceitos basilares da $\mathrm{AD}$, exatamente por ser através desta que percebemos o constante jogo de forças e de relações constituintes resultantes do processo discursivo. Segundo Pêcheux (1997, p. 77), 
Um discurso é sempre pronunciado a partir de condições de produção dadas: por exemplo, o deputado pertence a um partido político que participa do governo ou a um partido da oposição; é portavoz de tal ou tal grupo que representa tal ou tal interesse, ou então está 'isolado', etc. Ele está, pois, bem ou mal, situado no interior da relação de forças existentes entre os elementos antagonistas de um campo político dado. O que diz, o que anuncia, promete ou denuncia, não tem o mesmo estatuto conforme o lugar que ele ocupa; a mesma declaração pode ser uma arma temível ou uma comédia ridícula segundo a posição do orador e do que ele representa, em relação ao que diz. Um discurso pode ser um ato político direto ou um gesto vazio, para 'dar o troco', o que é uma outra forma de ação política

O sujeito se reconhece em pontos de estabilização dos sentidos e se constitui sóciohistoricamente sob a forma de pontos de estabilização que produzem o sujeito, com, concomitantemente, aquilo que lhe é dado ver, compreender, fazer, temer, esperar etc. Nesta perspectiva, temos, na leitura das obras de lambe-lambe, vestígios da relação do sujeito no espaço, na história e na ideologia de sua época, isto é, temos detritos e restos simbólicos do que foi e é vivenciado em sua historicidade e a partir dos processos de significação. Ao se (res)significar, a mulher e seu corpo os fazem atravessados pela memória, sendo possível retomar uma memória de um ideal de mulher nessas obras, sendo este de uma mulher de alto poder aquisitivo, cisgênero e heterossexual.

Por memória, essa pode ser:

[...] pensada discursivamente, [que] refere-se ao saber discursivo, ao fato de que todo dizer se produz por um já-dito. [Ou seja], todo dizer é já gesto de interpretação, posição face a memória. Para significar, nossas palavras já fazem sentido, se produzem em uma memória significativa, para que possam ser interpretadas. (Orlandi, 2003, p. 14).

Embora utilizemos palavras que já fazem sentido pela memória, elas passam por duas formas de esquecimento, segundo Pêcheux (1997), a primeira (esquecimento um) apaga-se ao fato de que os sentidos não começam no próprio sujeito do discurso; já a segunda (esquecimento dois) aponta que o dizer sempre poderia ser outro e que produz, em nós, uma ilusão de que somente pode-se dizer de uma forma quando haveria uma relação direta entre o pensamento/linguagem/mundo. Logo, ao analisar os sentidos depositados nas obras, é preciso abdicar da crença da transparência e unicidade de um dizer.

Todavia, como bem pontuado por Orlandi (2007), o discurso materializa e veicula a ideologia dominante, produzindo em si efeitos de evidências para o sujeito, sendo a ideologia um mecanismo que naturaliza um sentido apenas, e silencia outros tantos que são tidos como indesejáveis. Com isso, é possível perceber que há uma determinação ideológica de todo dizer, proporcionando ao sujeito uma ilusão de transparência da/na linguagem, ou seja, de que algo corresponde sempre a um dizer determinado e único, bem como uma relação neutra com o mundo; efeitos esses resultantes da interpelação ideológica desde o início já presentes, que sobre determinam sujeitos e sentidos. 
O sujeito, então, conforme Orlandi (2007), ao se posicionar discursivamente, está assujeitado à ordem do discurso em dois níveis: o da enunciação e o do enunciado. O nível do enunciado, denominado também como intradiscurso, ancora-se ao eu, ao aqui e ao agora, ao que se manifesta na fala do sujeito e que atualiza as redes de filiações de sentidos já ditos antes. Já o nível da enunciação, denominado como interdiscurso, diz respeito ao saber discursivo, às retomadas de sentido que se produzem a partir da constituição dos sentidos tidos como possíveis e pertinentes àquele sujeito naquela situação.

Orlandi (2012) parte das condições de produção do capitalismo, que transforma tudo em produto, inclusive os corpos, para afirmar que essas condições fazem emergir efeitos de evidências de um sujeito que crê em sua onipotência, em ser o único ponto de origem de um enunciado. Este posicionamento constitui-se de uma ilusão, como já dito, à medida que realiza um apagamento da construção histórica de um enunciado, esquecendo-se do real que o constitui e que aparece nas falhas e furos, incompletudes e apagamentos dos dizeres. O sujeito é interpelado, desde o início, já que, ao nascer o bebê, os pais e o meio social o introduzem na linguagem e nas condições sócio, históricas e ideológicas nas quais se inserem. Oferecendo significantes, através da fala, sentidos já pré-existentes que irão constituí-los e afetar a forma como este ocupa uma posição no discurso. Assim, o sentido nunca é literal, haja vista que a conjuntura sócio-histórica o determina, orientando uma série de representações imaginárias, que irrompem em uma determinada formação discursiva (FD).

[...] o sentido de uma palavra, de uma expressão, de uma proposição, etc., não existe 'em si mesmo' (isto é, em sua relação transparente com a literalidade do significante), mas, ao contrário, é determinado pelas posições ideológicas que estão em jogo no processo sócio-histórico no qual as palavras, expressões e proposições são produzidas (isto é, reproduzidas). (Pêcheux, 1988, p. 146).

As condições sócio-históricas afetam os sentidos possíveis para cada sujeito em sua determinada posição social (e política) na qual se insere. Em virtude disso, a materialidade do discurso existe em acordo com a historicidade. Trabalhar com o(s) discursos(s) implica, então, tocar o tênue terreno da memória discursiva, ou seja, é preciso considerar que as palavras guardam vestígios dos seus usos sociais em outros contextos e que existe, de certo modo, um saber discursivo sobre isso (Orlandi, 2007). A memória, no contexto discursivo, é tratada como interdiscurso, isto é, pertence "aquilo que fala antes, em outro lugar, independentemente" (Orlandi, 2007, p. 31) e é o que torna possível cada tomada da palavra pelo sujeito que, no ato de enunciar, atualiza a significação pré-construída das palavras, fazendo, com isso, falar rupturas nos sentidos estabilizados, instalando "novos" sentidos ao já-dito ou mantendo aquilo que já está posto como sentido dominante (intradiscurso). 
É possível perceber que há uma determinação ideológica de todo dizer, o sujeito tem a impressão de que há uma transparência da/na linguagem, assim como idealiza que nela se mostra apenas uma relação neutra com o mundo, sendo a ideologia o mecanismo criador dessa ilusão, ou seja, de que algo corresponde sempre a um dizer determinado e único.

A arte surge, então, como uma forma de (r)existir, (re)existir e (re)atualizar essas significações pré-estabelecidas, utilizando-se da paráfrase (repetição do já-dito, do mesmo, do igual) e/ou da polissemia (ruptura do já-estabelecido) para produzir seu dizer, ancorando-se em um discurso já dito, mesmo com esses dizeres já sendo silenciados em alguns momentos da história. É por meio do irromper deste no poste, e no post, que o político e simbólico se confrontam de modo particular, graças à linguagem que se presta a se simbolizar. É por meio das condições sócio-histórico-ideológicas inerentes a todo processo discursivo que podemos dizer que há ou não uma reatualização da memória de violência sobre o corpo da mulher, seja ela pela apropriação do corpo da mulher enquanto público, objetificado, seja para imposição de um padrão de corpo a ser tido e alcançado. Ou seja, tomamos, nas obras, diferentes formas de tomar/considerar o corpo enquanto aquele que é abusado tanto sexualmente, quanto pela imposição de padrões físicos.

Pensando então nesses três níveis de produção de um discurso temos: a constituição, a formulação e a circulação. Orlandi (2012) ressalta a importância desses três níveis discursivos como um processo em que a constituição determina a formulação, pois só podemos dizer (formular) se nos couber uma perspectiva do dizível (interdiscurso, memória). Além disso, todo dizer se encontra na convergência dos dois eixos: da memória (constituição) e da atualidade (formulação) de um dizer, sendo a partir desse jogo que escapam todos os sentidos (Orlandi, 2012). Apesar de apresentarmos esses momentos de forma separada, eles sempre devem estar integrados quanto à produção do sentido de um discurso. Para Orlandi (2007), a constituição é uma "atividade estruturante de um discurso determinado, por um falante determinado, para um interlocutor determinado, com finalidades específicas" (Orlandi, 2003b, p. 125), assim, a constituição de um dizer só ocorre por meio de uma memória, ou seja, a partir de sentidos já-ditos, estando esses relativamente estáveis em determinada formação social. Este processo se realiza no nível interdiscursivo, quer seja por formulações de um préconstruído, quer seja por forma de um atravessamento de sentidos na formulação do dizer.

A formulação do discurso, no que lhe toca, realiza-se no nível intradiscursivo por meio de uma linearidade dos sentidos. Conforme Courtine (2016, p. 24), no nível da formulação, há um desnivelamento interdiscursivo do enunciado, "provocando um achatamento em uma superfície única de formulação articulada”. Este achatamento ocorre por uma 
"horizontalização" da dimensão vertical de constituição dos discursos. Segundo o mesmo autor, essa horizontalização:

[...] é contemporânea à apropriação por um sujeito enunciador (doravante, L), que ocupa um lugar determinado no seio de uma FD, de elementos do saber da FD na enunciação do intradiscurso de uma sequência discursiva, está em uma situação de enunciação dada. (Courtine, 2016, p. 24).

Observamos, então, que os discursos são constituídos e estruturados por uma relação existente entre atualidade e memória, sendo este um processo em que determinados sentidos podem ser atualizados, estando condizentes com a formação discursiva na qual se inscrevem os sujeitos na produção do dizer. Tomar o discurso enquanto objeto teórico e analítico da AD provoca considerar o funcionamento linguístico (ordem da língua) e as condições de produção de um dizer (exterioridade). Assim, é na circulação que certos dizeres se regularizam no meio social, tendo em vista as condições de produção do discurso específicas de cada momento no qual se insere um dizer, como também de cada formação social do qual ele parte.

Dessa forma, ao pensarmos na produção das obras de lambe-lambe por parte dessas contas, refletimos sobre os desdobramentos que a internet proporciona(ou) para a circulação de dizeres sobre a mulher e seu corpo, por meio de novas formas de circulação e de produção de um discurso, que, embora tenha seus processos (formulação, constituição e circulação) atuando de forma inseparáveis, tem como ângulo de entrada a circulação dos sentidos. Assim, com o digital, é a circulação que dá corpo aos sentidos e não a formulação, item que veremos melhor no capítulo 3, sobre as condições de produção que o digital nos proporciona.

Com já posto, propomo-nos a realizar um gesto de interpretação teórico e analítico acerca da relação do corpo feminino e sua poética em discurso no movimento da língua com a história e suas implicações no processo de subjetivação que se estabelece nas obras de arte de lambe-lambe. Temos, assim, um trabalho que visa à reflexão sobre os processos de produção dos sentidos acerca do corpo da mulher, nas obras, por meio de um olhar discursivo que considera o real da língua e o real da história:

Tudo isso, obviamente, implica numa certa percepção da relação entre realidade histórica materialidade linguística e a existência do sujeito: põe-se em questão a metafísica confortável que considera as classes como objetos pré-construídos e autocentrados, o sujeito com unidade ativa de uma consciência intencional e a língua como instrumento de comunicação das ações e expressões desse sujeito [...]. (Gadet \& Pêcheux, 1991, p. 98).

Pretendemos, com isso, analisar a poesia textualizada nos lambes, por um viés de análise a partir das materialidades discursivas, sendo essa uma tentativa de teorizar o real e a poesia, ou seja, uma busca por observar na poesia aquilo que a constitui como traço do real pela falha da língua. Realizamos, então, uma reflexão no sentido de problematizar o poético 
em sua relação inexorável com o político, estando as obras que nos propomos a analisar em uma forte ligação à posição de Gadet e Pêcheux (2010) de que o poético não é o domínio do pensamento, mas uma acepção da língua, em que o equívoco e a contradição materializam seu ponto de encontro com a história: o lugar da poesia tecida no negativo, no absurdo, na metáfora (Gadet \& Pêcheux, 2010).

De acordo com Sousa (2016, p. 156), teorizar acerca da poesia por uma perspectiva da $\mathrm{AD}$ corresponde em um "jogo tenso e pendulante entre dizer e apagar no dito, entre presença e falta, entre tentativa de preenchimento e vazio, aponta um trabalho nas fronteiras e bordas, tão caro ao linguista e ao (psi)analista.”, ao qual o analista de discurso passa a se haver durante o processo de análise. A autora, ao realizar seu percurso pela obra de Lacan (19591960; 1962; 1964; 1976-1977), e pela obra de Pêcheux (1983) e Gadet e Pêcheux (19661983), esta parte da concepção de um sujeito faltante enquanto aquele que traz em si o que existe de aberto e faltoso, e que, contudo, não se completa ou tampona, "mas configura as idas e vindas do significante, em voltas e novos turnos de procura do objeto que é/está perdido para sempre" (Sousa, 2016, p. 156).

Apesar de muito diferentes entre si, esses dois campos teorizam sobre a língua a partir do que esta apresenta de presença e de ausência, como também o fato de a língua comportar um impossível de dizer e significar tudo, sendo tal fato constitutivo de todo ser e dizer que adentra a linguagem. Sousa trabalha com a concepção de um sujeito faltante, pois o sujeito que trabalhamos na Análise de Discurso é submetido a um real da língua, um impossível de se dizer, completar e fechar, que se estabelece pelas idas e vindas dos significantes em discurso. Ou seja, para a AD estamos diante de um sujeito à/da linguagem, faltoso e interpelado em sujeito pela ideologia para que, assim, se inscreva o seu dizer.

Defronte ao que não cessa e não se completa, essa fenda constitutiva da/na língua, que nada por contorná-la, no qual "o verbo falta impedido de dar conta do buraco que não consegue tamponar" (Sousa, 2016, p. 157), faz com que, na palavra, se dê a ver que: "a cada tentativa de nomear, o inominável compare como centro em torno do qual todos os movimentos simbólicos orbitam, em torno do qual o sujeito faz giros de desejar. E faz poesia" (Sousa, 2016, p. 157). Dessa maneira, consideramos que, na poesia, cabe ao poeta lidar com a incompletude do simbólico, sendo que este, segundo Leite (2011, p. 34), diz respeito não à falta de palavras para simbolizar algo, mas ao que verdadeiramente falta na palavra.

Gadet e Pêcheux (2010) tomam como objeto para análise em sua obra as ambiguidades, as derivas de sentido, as falhas e as incompletudes que eram vistos pela linguística tradicional enquanto erros a serem solucionados. Foi a partir da obra "A língua 
inatingível" que Gadet e Pêcheux (2010) desenvolveram que a linguagem poética é uma linguagem à parte que se manifesta em um funcionamento exclusivo (Gadet \& Pêcheux, 2010, p. 63). Para esses:

[...] a poesia não tem lugar determinado na língua porque ela é literalmente coextensiva a esta última, do mesmo modo que o equívoco: talvez não haja poesia. Não há poesia porque o que afeta $\mathrm{e}$ corrompe o princípio da univocidade na língua não é localizável nela: o equívoco aparece exatamente como o ponto em que o impossível (linguístico) vem aliar-se à contradição (histórica), o ponto em que a língua atinge a história (Gadet \& Pêcheux, 2010, p. 64).

Dessa forma, o encontro da Língua em sua incompletude com a História se corrobora enquanto um elemento para a formulação de um dizer que é fruto desse encontro. Diante disso, toda língua está sujeita aos mesmos funcionamentos. O poeta é, então, aquele que enfrenta esta incompletude e leva as propriedades da língua até as últimas consequências, concebendo qualquer ponto de cessação e impondo o gesto político da interpretação. É, pois, um gesto político, já que a poesia fura a ilusão de opacidade da língua e aponta para a errância dos sentidos dominantes, para sua não-correspondência com o mundo, para sua arbitrariedade e incompletude, deflagrando, com isso, o funcionamento político que a poesia possibilita.

Com efeito, o poeta joga com a equivocidade, ocasionando a aparição de um ponto em que o impossível do campo linguístico alia-se à contradição posta na história confirmando, assim, a tese de Pêcheux (1988 [1978]), que defende que o processo metafórico está em relação ao processo revolucionário, uma vez que desloca as evidências de sentido. Logo, situar a interpelação ideológica por uma via que se constitui sem falhas, enfraquecimentos ou brechas, em que se troca facilmente uma palavra por outra, é tanto a definição da metáfora, quanto o ponto em que o ritual se estilhaça no lapso (Pêcheux, 2009).

Segundo Sousa (2016, p. 161), "temos a urgência de tomar a língua em sua plástica equivocidade, marcada pela falta e pelo impossível que lhe são constitutivos, o que significa inferir tomá-la em sua condição de poesia”. Nesse caminho, partindo de uma perspectiva teórica que assume a língua como objeto próprio de análise, tomada como uma estrutura aberta, que falha, que faz metáfora e brinca o jogo significante na relação com a contradição da História, temos, então, "[...] uma série de efeitos ideológicos que emergem da dominação e que trabalham contra ela por meio das lacunas e falhas no seio da própria dominação [...]" (Gadet \& Pêcheux, 1991, p. 97), efeitos esse que analisamos no percurso deste trabalho através das obras de lambe-lambe que fazem circular sentidos outros para o corpo da mulher, desnaturalizando sentidos que se instauram a partir do efeito da ideologia na língua.

Nesse processo de (des)estruturação dos sentidos que concebemos com as obras de lambe-lambe, a memória atua como elemento fundamental na regularização dos dizeres. É a 
partir dela que os implícitos são restabelecidos e os sentidos são atualizados, sendo sempre passíveis de se tornarem outros. Assim, cada novo dizer, mesmo que filiado a uma mesma memória discursiva, se configura enquanto uma paráfrase do que lhe antecede, trazendo em si a possibilidade de diferentes leituras e formulações de sentido.

Como já colocamos, a memória para Michel Pêcheux ([1983] 1999), p. 52):

[...] seria aquilo que, face a um texto que surge como acontecimento a ser lido, vem restabelecer os 'implícitos'; (quer dizer, mais tecnicamente, os pré-construídos, elementos citados e relatados, discursos-transversos, etc.) de que sua leitura necessita: a condição do legível em relação ao próprio legível.

Para Pierre Lévy (1999, p. 130), a cibercultura é a expressão do desejo de constituição de um laço social que se estabelece a partir da reunião de interesses comuns. Para este autor, as comunidades virtuais "exploram novas formas de opinião pública", buscando deslocar dizeres já estabilizados na memória da sociedade. Como desenvolveremos nas análises, nas contas de Instagram aqui trabalhadas, há uma tentativa por parte dos dizeres das obras de romper com uma memória sobre a mulher, legitimada ainda hoje em nossa sociedade, e isso ocorre na tentativa de formulação, constituição e circulação de novas discursividades na rua e na rede.

Para Orlandi (2007, p. 31), "é o saber discursivo que torna possível todo dizer e que retorna sob a forma do pré-construído, o já-dito que está na base do dizível, sustentando cada tomada da palavra". Assim, o conceito de memória é abordado como interdiscurso que “disponibiliza dizeres, determinando, pelo já-dito, aquilo que constitui uma formação discursiva em relação a outra. Dizer que a palavra significa em relação a outras é afirmar essa articulação de formações discursivas dominadas pelo interdiscurso em sua objetividade material contraditória" (Orlandi, 1999, p. 44).

Assim, há um sentido dominante, aquele que é dado como verdadeiro e que já foi veiculado e legitimado pelo homem. O sujeito, então, é capturado pelo já-dito e preso à memória discursiva. O que ele diz é uma retomada do que foi capturado por ele. No entanto, é possível que o sujeito atualize essas significações, utilizando-se da paráfrase (repetição do jádito, do mesmo, do igual) e da polissemia (ruptura do já-estabelecido) para produzir seu dizer, ancorando-se em um discurso já dito. De acordo com Orlandi (2007, p. 36): “A paráfrase representa assim o retorno aos mesmos espaços do dizer. Produzem-se diferentes formulações do mesmo dizer sedimentado". Já na polissemia entraria como uma tentativa de ruptura de um dizer já pré-estabelecido já que a partir dela "temos é o deslocamento, ruptura de processos de significação. Ela joga com o equívoco" (Orlandi, 2007, p. 36). 
Muitas das obras que aqui vamos tratar utilizam-se desse processo para resistir à um dizer já pré-estabelecido sobre a mulher. É nesse sentido que iremos compreender as obras de Lambe-Lambe, do ponto de vista da AD, distinguindo a criatividade da produtividade. Para Orlandi (2007, p. 37), a criatividade “[...] implica na ruptura de processos de produção da linguagem, pelo deslocamento das regras, fazendo intervir o diferente, produzindo movimentos que afetam os sujeitos e os sentidos na sua relação com a história e com a língua. Irrompem assim sentidos diferentes”. Dessa forma, é possível perceber que as obras de lambelambe, de caráter poético, publicadas nas contas devem ser vistas como um movimento de criatividade capaz de oferecer resistência às formações discursivas presentes na ideologia. Esses estabilizam certos sentidos, mas também rompem com uma memória estabilizada pela história e pela sociedade sobre o feminino e seu corpo.

Nessa seção, debruçamo-nos na construção dos conceitos discursivos que foram utilizados neste trabalho, evidenciando para o leitor a forma como se realiza o trabalho interpretativo do sujeito, do sentido e da sociedade na posição de analista do discurso. $\mathrm{Na}$ próxima seção, nos ateremos a compreender as configurações do digital e de que modo essas configurações afetam a relação dos sujeitos com os sentidos sobre a mulher e seu corpo. Procuraremos, também, analisar a relação entre rua e rede que se apresenta na materialidade dos lambes, posta enquanto uma metonímia do espaço público, onde rua e rede se convergem a fim de marcar movimentos de sentido entre sujeitos e o meio social. 
3 REDES E RUAS: UM ESPAÇO EM-COMUM ONDE ARTE E POESIA SE TECEM

Figura 6 - Obra da artista visual brasileira Nega Hamburguer

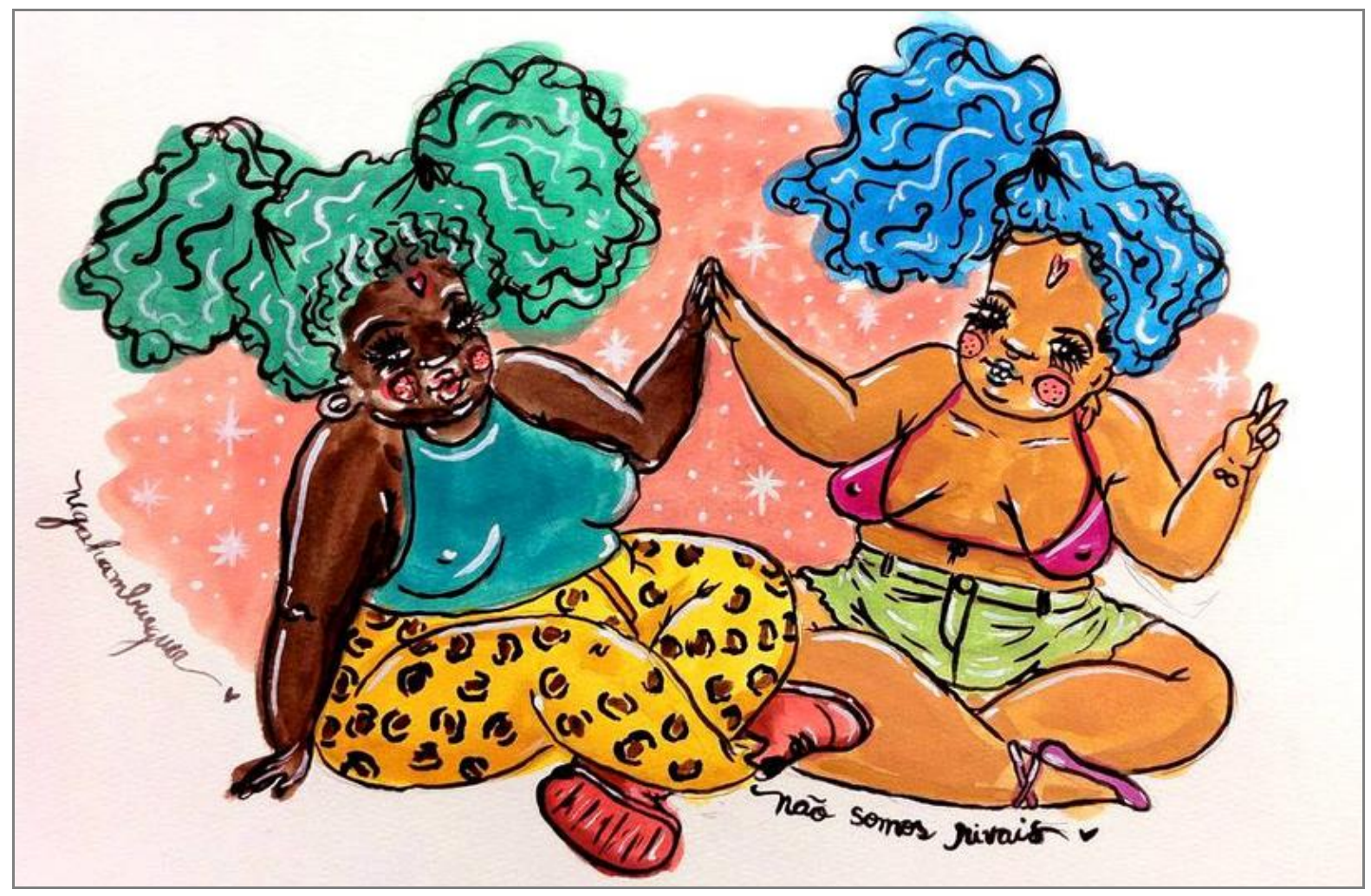

Fonte: https://naomekahlo.com/5-grafiteiras-que-voce-precisa-conhecer/

eu era música mas suas orelhas tinham sido cortadas por primos e tios e homens nossos corpos manipulados pelas pessoas erradas que mesmo numa cama segura sentimos medo

(Rupi Kaur, 2017) 
Nesta seção, buscamos compreender de que modo as configurações do digital determinam e dão corpo à relação dos sujeitos com os sentidos sobre o corpo feminino nas obras de lambe-lambe que circulam em alguns perfis do Instagram. Buscamos evidenciar a relação entre rua e rede que se apresenta na materialidade dos lambes enquanto uma metonímia do espaço público, marcada por movimentos de sentido entre sujeitos e grupos sociais.

Nas obras de lambe-lambe, observamos o estabelecimento de uma mesma rede de sentido, um espaço em comum, que faz transbordar a narratividade de ambos os espaços: rua e rede. Verificamos que esses campos se deslocam nas obras, estabelecendo uma relação de entremeio entre o mundo e a linguagem a partir da narratividade das obras, pois o poste é atravessado pela narratividade do digital. Ao ter um @ a ser acompanhado nas redes e o post, nos perfis que nos colocamos a estudar, está significado pelo poste, já que nas fotografias se observa a presença desta materialidade na rua, em um poste.

Tentaremos compreender a narratividade posta nas obras de lambe-lambe compartilhadas em rede para, então, compreender o movimento tido por essas obras de uma relação de entremeio capaz de estabelecer uma relação entre o mundo e a linguagem. Ficamnos algumas questões a serem respondidas nesse capítulo como: a) Como se organiza a discursividade dos lambes: pelo digital? Pela rua? b) Como esse espaço de entremeio funciona na narratividade dos lambes? Como a partir dessa relação de entremeio (complementar, mas também contraditória) se produz outros sentidos possíveis para o espaço público? Segundo Orlandi (2001), a tecnologia de linguagem configura-se como uma tecnologia de escrita. Nesse sentido, pensar o modo de circulação de sentidos sobre a mulher e seu corpo em rede implica em compreender como a escrita na materialidade digital, regulada por certos imaginários, determina a formulação de sentidos acerca do corpo feminino em nossa contemporaneidade.

Para Dias (2016, p. 173), materialidade digital é:

\footnotetext{
o processo de significação que se dá pela emergência da discursividade digital na forma material do discurso (texto, imagem, cena urbana, etc.), e em certo meio material (aplicativo, outdoor, rede social, cidade etc.). [...] a materialidade digital inclui tanto o meio material que, por sua vez, reúne de modo constitutivo as tecnologias do urbano às tecnologias digitais, quanto a forma material, que, por seu lado, reúne língua e história.
}

Os processos de significação, então, se relacionam com a e na história da escrita e com os espaços onde ela é praticada. A história e o político são constitutivos desse processo de exterioridade na materialidade digital. Assim, e a partir de uma linha ilusória que demarca uma separação exata entre os espaços físico e digital, considerarmos importante o estudo das 
práticas online e off-line de formulação, constituição e circulação de sentidos como práticas que estão materialmente ligadas e que apresentam sua condição de produção específica e que se realiza, como efeito, na história.

Deste modo, no presente capítulo, buscamos compreender de que modo o digital determina a relação dos sujeitos com o sentido de/sobre o corpo feminino, partindo do fato de que o digital afeta a formulação das obras de lambe-lambes e de sua poesia na rua, na cidade, da mesma forma que, a rua - lambe no poste - está significada no Instagram. Assim, podemos afirmar que partimos de um lugar em-comum, onde rua e rede transbordam sentidos, deslocando-se para estabelecer uma relação de entremeio entre mundo e linguagem. A cidade é tida como o centro de debates e de circulação de sentidos das mais diferentes instâncias. Segundo Orlandi (2004, p. 12), podemos definir por cidade "um núcleo relativamente grande, denso e permanente de indivíduos socialmente heterogêneos", ou seja, um núcleo em que o corpo social e o corpo urbano estão atrelados ao ponto de, ao olhar para um, estarmos olhando para o outro.

Ademais, podemos pensar que "observar [a] cidade é procurar compreender as alterações que se dão na natureza humana e na ordem social” (Orlandi, 2004, p. 12). Nesse sentido, ao contemplar a narratividade da cidade, estamos também testemunhando as movimentações existentes, o mundo e a linguagem. Orlandi (2004) afirma que a cidade constitui o homem e é, também, por ele constituída, sendo esta ação de um processo de subjetivação que nunca acaba, em constante movimento. Logo, entendemos que:

A cidade não é a cidade empírica, é traçado do funcionamento do interdiscurso na forma como o sujeito se individua na relação com o Estado: deslocando os sentidos das políticas públicas urbanas que administram artefatos alocados nesse espaço por eles, na relação com o corpo dos sujeitos: rua, calçada, muro, banco, semáforo, etc. (Orlandi, 2014, p. 82).

A cidade tem, assim, sua materialidade significativa, um corpo simbólico que produz sentidos em movimento. A heterogeneidade da urbanidade se mostra na riqueza da relação do indivíduo com outros indivíduos e com tudo que se constitui a cidade, constituindo um espaço de subordinação e dispersão. Ao voltarmos o nosso olhar para a cidade, estaremos em contato com:

[...] a riqueza que se mostra na relação do indivíduo com outros indivíduos e com tudo que se constitui a cidade. Heterogeneidade, mas padronização, subordinação às exigências da comunidade maior na medida em que faz parte de movimentos coletivos, mas, ao mesmo tempo, dispersão, e, ainda, individualidade. (Orlandi, 2004, p. 12). 
Ou seja, analisar os movimentos existentes na cidade nos coloca diante dos movimentos realizados por sujeitos que ali vivem e se constituem com o meio social. Essas movimentações seguem um padrão imposto pelo social, pelo histórico e pela ideologia ideologicamente presente na memória discursiva. No entanto, outras vezes podemos perceber gestos de enfrentamento de como o espaço afeta - e é afetado, de certo modo - o - pelo sujeito, uma ruptura com a memória socialmente estabilizada, formulando-se assim novos dizeres. Orlandi (2004, p. 12) afirma que tal padrão existe, pois "não podemos prescindir de pensar a cidade em termos de conceitos como o de política econômica, de zona urbana, de autoridade urbana, aliando-se esses conceitos econômicos (mercado) a conceitos políticos”, já que a cidade se apresenta como um amontoado de instituições políticas e administrativas que (des)“organizam" e estabelecem a (des)“ordem” do urbano, além de encontrarmos estabilizações furadas, que mostram que não há uma homogeneidade nos sujeitos que ali vivem. Assim, o sujeito urbano:

[...] como está produzindo sentidos na cidade - textualizando sua relação com objetos simbólicos no mundo - produz uma realidade estruturada da maneira como esse espaço o afeta, reverberando sentidos do/no imaginário urbano. Enquanto analistas, temos então nos textos produzidos, que são historicamente constituídos, a presença dos vestígios desse modo pelo qual os sujeitos estruturam e se estruturam nessa realidade urbana. (Orlandi, 2001, p. 10).

Nessa perspectiva, temos na leitura da cidade vestígios da relação do sujeito com o mundo significada na linguagem, que apresenta um sujeito que circula sentidos no espaço, na história e na ideologia de sua época, isto é, que faz circular detritos e restos simbólicos do que foi e é vivenciado em sua historicidade e a partir dos processos de significação. Ao se (res)significar, a cidade o faz atravessada pela memória, sendo esta:

[...] pensada discursivamente, [que] refere-se ao saber discursivo, ao fato de que todo dizer se produz por um já-dito. [Ou seja], Todo dizer é já gesto de interpretação, posição face a memória. Para significar, nossas palavras já fazem sentido, se produzem em uma memória significativa, para que possam ser interpretadas. (Orlandi, 2003, p. 14).

Como já dito, embora utilizemos palavras que já fazem sentido pela memória, elas passam por duas formas de esquecimentos, segundo Michel Pêcheux (1997). A primeira apaga-se ao fato de que os sentidos não começam no próprio sujeito do discurso; já a segunda aponta que o dizer sempre poderia ser outro e que produz, em nós, uma ilusão, de que somente pode-se dizer de uma forma quando haveria uma relação direta entre o pensamento/linguagem/mundo. Logo, ao analisar os sentidos produzidos pela cidade, é preciso abdicar da crença da transparência e unicidade de um dizer. 
Contudo, como bem pontuado por Orlandi (2009), também já dito acima, o discurso materializa e veicula a ideologia dominante, produzindo em si efeitos de evidências para o sujeito, sendo a ideologia um mecanismo que naturaliza um sentido apenas e silencia outros tantos que são tidos como indesejáveis. A partir disso, é possível perceber que há uma determinação ideológica de todo dizer, indicando que pelo mecanismo de silenciamento fornecido pela ideologia, o sujeito tem a impressão de que há uma transparência da/na linguagem, assim como idealiza que nela se mostra apenas uma relação neutra com o mundo, sendo a ideologia o mecanismo criador dessa ilusão, ou seja, de que algo corresponde sempre a um dizer determinado e único.

O sujeito, conforme Orlandi (2009), ao se posicionar discursivamente está assujeitado à ordem do discurso em dois níveis: o da enunciação e o do enunciado. O nível do enunciado, denominado também como intradiscurso, ancora-se ao eu, ao aqui e ao agora, ao que se manifesta na fala do sujeito e que atualiza as redes de filiações de sentidos já ditos antes. Já o nível da enunciação, denominado como interdiscurso, diz respeito ao saber discursivo, as retomadas de sentido que se produzem a partir da constituição dos sentidos tidos como possíveis e pertinentes àquele sujeito naquela situação, conforme já escrito no capítulo anterior.

Por fim, retomando outra fala de Orlandi, esta mesma autora (2009) assevera que a memória se ancora no interdiscurso, já que um dizer não é propriedade particular, mas é atingido pela história e por outros dizeres historicizados e marcados pela ideologia e pelo poder. A arte surge, então, como uma forma de re(xistir) e (re)atualizar essas significações pré-estabelecidas utilizando-se da paráfrase (repetição do já-dito, do mesmo, do igual) e/ou da polissemia (ruptura do já-estabelecido) para produzir seu dizer, ancorando-se em um discurso já dito. Mesmo esses dizeres sendo silenciados em alguns momentos da história, é por meio do irromper do asfalto que, como pontuado por Orlandi (2014), no discurso urbano, o político e simbólico se confrontam de modo particular, graças à linguagem que se presta a simbolizar a/na materialidade do urbano, concebido como um espaço político, de divisão e da dissimetria, portanto, produzindo seus restos.

[...] pensamos a cidade como espaço político e simbólico em que a escrita acontece em suas formas de textualização. Espaço material concreto que funciona como um sítio de significação e que demanda gestos de interpretação particulares a sua forma material. Portanto, à forma (material) da cidade. Espaço político, logo, espaço da divisão, da dissimetria, do resto (Orlandi, 2014, p. 71).

Tudo isso possibilita analisar a cidade discursivamente a partir da forma como sujeito se imprime nela, como é o caso dos "flagrantes urbanos", abordados, por Orlandi (2001), 
enquanto formas de o sujeito se (res)significar em sua poesia, incluídas no formato material da cidade. Para Orlandi (2004), afirma que formular é dar corpo às palavras e é pelas condições de produção que o sujeito formula seu dizer, sua vida, seus sentidos e suas palavras. A cidade em seus flagrantes nada mais é do que uma forma de o sujeito (res)significar com sua poética, fazendo dessa formulação uma forma de fazer alguns sentidos circularem ali. Mas que sentidos são esses a serem transpostos para a cidade? Quem decide esses sentidos? Conforme a linguista brasileira, o jogo político é quem decide esses sentidos, já que eles postos na cidade por meios de flagrantes nada mais são do que restos, formas de resistência ao imaginário burocrático do urbano que impõem o que pode e o que não pode aparecer discursivamente. A autora ratifica que,

Sem espaço vazio, não há possível, não há falha, não há equívoco. Tudo se dá previamente, definitivamente projetado. O apagamento do social pelo urbano desfaz o político livrando a cidade à violência. Deixam-se de levar em conta modos sociais de produção de sem tidos próprios à cidade que trazem o imprevisível, o não calculado, o que não se reduz ao plano projetado. (Orlandi, 2004, p. 35).

Walty (2014), em sua obra “A rua da literatura e a literatura da rua” traz o conceito de rua a partir de Jane Jacobs, autora que se contrapõe à ideia de rua enquanto um espaço de circulação para desenvolver a ideia de ponto de encontro com a diversidade. Assim, a ideia de que uma rua segura não existe pelo seu caráter de enclausuramento e seguridade, e sim por ser um lugar de encontro com uma variedade de sujeitos e discursividades, proporcionando-nos proximidade o suficiente para se escutar o que ali acontece é abordada na obra. E é a partir dessa ideia de espaço, em sua relação com as trocas culturais, que se intenta analisar nessa pesquisa as configurações do público na narratividade urbana que é compartilhada em rede. Para Walty (2014, p. 10):

A imagem da rua como espaço físico-geográfico e político-social pode ainda ser alargada com o exame da construção da própria história da literatura brasileira como uma possível via (ou vias) de circulação de textos diversos, levando em conta o contexto da enunciação.

A autora ainda aponta a rua como um espaço de construção histórica da literatura brasileira. Se pensarmos sobre as obras de lambe-lambe que aqui nos propomos a estudar e o fato de que algumas das autoras dessas obras terem publicado livros de suas poesias que antes circulavam na rua e na rede, em obras literária, estamos olhando para o fato de essas obras se constituíram pelo espaço da rua e da rede, já que suas obras circulavam em ambos os espaços, tendo grande visibilidade na rede. Assim, rede e rua constituem também a história da literatura brasileira com a entrada das/dos Instapoetas no campo da literatura. É a partir dessa construção de Walty (2014), sobre a relação entre literatura e espaço público, que nos propomos a analisar a relação existente entre as narratividades do lambe-lambe na rua e na 
rede e a construção do espaço público. Como já abordado, rua e rede se deslocam para a materialidade dos lambes a fim de estabelecer uma relação de entremeio, para a constituição de sentidos entre o mundo e a linguagem. Como bem coloca Orlandi (1995) o texto mostra como se organiza uma discursividade. Assim, o que nos interessa é o que o texto organiza em sua discursividade, em relação à ordem da língua e a das coisas: a sua materialidade.

\footnotetext{
O sujeito e o sentido, ao se constituírem, o fazem necessariamente na conjunção dessa relação. Estão expostos ao acaso (mundo) e ao jogo (linguagem), mas também à memória (mundo) e à regra (linguagem). Onde está o mesmo, está o diferente. A separação entre paráfrase e polissemia não é clara e nem permanente. (Orlandi, 1998, p. 93, grifo nosso).
}

Orlandi (2007) formaliza que a história afeta a linguagem e os sentidos e desse encontro surge o texto. Assim, a textualidade é a própria história fazendo sentido no texto. Como já vimos, a AD procura trabalhar nesse lugar nesse encontro entre a ordem da língua e a ordem da história. Para esta autora, "um texto não é um documento, mas um discurso" e nós, analistas do discurso, concentrar-nos-emos a observar, "no movimento contínuo entre descrição e interpretação - a memória” (Orlandi, 2007, p. 115).

Para Dias (2018, p. 119), “a cidade contemporânea modifica-se. Seus percursos metaforizam percursos de outra ordem, com outra espessura discursiva constituída por uma mobilidade rarefeita numa espacialidade retigráfica". Tal espacialidade se dá pela alta mobilidade presente com a conectividade, que produz uma maior conexão entre os sujeitos. Nesse processo de conectividade, como bem aponta a autora, há também um modo próprio de constituição do sujeito, já que o corpo discursivo do sujeito está atado ao corpo da cidade. Assim, vemos um movimento nos sentidos, estando estes afetados pela história da evolução tecnológica de nossa sociedade com o advento da conectividade. Ainda segundo Dias (2018), os discursos afetados pelo digital têm como cerne de suas investigações as formas de assujeitamento tidas no início do século XXI com o advento da tecnologia. Desde seu primeiro livro "Sujeito, sociedade e tecnologia: a discursividade da rede (de sentidos)" (Dias, 2012) o digital entra como condição de produção político-ideológica do discurso. Nesse trabalho, a autora desenvolve o ciberespaço como sendo um espaço discursivo de significação, constituindo, então, um espaço de linguagem, político e simbólico de construção de sentidos, caracterizado por uma temporalidade própria e um território não localizável no mundo físico.

Para nós, o movimento de subjetivação do sujeito não é indiferente às condições de produção, já que esse se estabelece a partir de movimentos sucessivos de assujeitamento que ocorrem com a passagem de indivíduo a sujeito (Althusser, 1970), pela interpelação 
ideológica, assim como pela submissão a nível simbólico e político, próprio do processo de individuação do Estado e suas instituições. Assim, o sujeito é afetado por uma articulação simbólico-política, através de discursos, instituições e práticas sociais, que tem como resultante a identificação (ou não) do sujeito às formações discursivas (Orlandi, 2007).

Para Orlandi (2012), esse espaço proporciona ao sujeito da contemporaneidade novas formas de circulação de sentidos, assim como outras maneiras de se relacionar em sociedade, destacando-se a velocidade para a formulação, constituição e circulação da informação, permitidas pelos “artefatos de produção do conhecimento". Refletimos nesta pesquisa se é possível estabelecer um ponto localizável em que os lambes dos perfis que analisamos circulam. Para Orlandi (2005), pensar a circulação seria pensar onde e como um dizer circula. No entanto, o objeto que aqui tratamos não nos possibilita apreender um ponto localizável de análise, já que, para Dias (2018), a margem entre rua e rede não tem fronteira.

Para Castells (2005, p. 17), o mundo em que vivemos tem se transformado em virtude da emergência das tecnologias da comunicação e da informação, sendo "um processo multidimensional, associado à emergência de um novo paradigma tecnológico, baseado nas tecnologias de comunicação e informação que começam a tomar forma nos anos 60 e que se difundiram de forma desigual por todo o mundo". O autor (2005, p. 17) afirma que a sociedade em rede possibilita:

\footnotetext{
uma estrutura social baseada em redes operadas por tecnologias de comunicação e informação fundamentadas na microeletrônica e em redes digitais de computadores que geram, processam e distribuem informação a partir de conhecimento acumulado nos nós dessas redes. A rede é uma estrutura formal. É um sistema de nós interligados.
}

Sendo então a rede uma estrutura interligada, objetivamos compreender o modo como as configurações do digital determinam e dão corpo à relação dos sujeitos com os sentidos sobre o corpo feminino nas obras de lambe-lambe. Segundo Romão (2005, p. 71), "o século XXI, nasce com marcas de silício nas veias, embalado pelo ideário de liberdade construído a partir da explosão das tecnologias de comunicação, especialmente aquelas que proporcionam velocidade, mobilidade e ubiquidade" e tais características produzem uma forma de mediação da linguagem, a partir das configurações do digital, desbocando, então, em um modo de funcionamento discursivo próprio ao digital.

As redes permitem ao sujeito uma vivência com a mobilidade e a capacidade de se encontrar em muitos locais, por meio das tecnologias da comunicação (computadores, celulares etc.), estabelecendo, assim, uma maior chance do encontro com o outro no espaço digital. No ciberespaço, sentidos diferentes orbitam em um mesmo local, produzindo sentidos, 
caracterizando, assim, a rede como um espaço heterogêneo. No entanto, este também é afetado relações de poder que possibilitam o emergir de certos sentidos, mas também velam e interditam outros. Tal fato ocorre pela incidência da ideologia na língua, que, ainda que de forma velada, interditam certos sentidos. Para Romão (2004, p. 72):

ao mesmo tempo em que os pontos e os nós compõem a geometria do trançado, há espaços de brechas, desvãos e buracos, que criam poros abertos, por onde escorregam vazios, escampam silêncios, escorrem os não-ditos e interditos. Há vãos intervalares entre os cantos de galo, há espaços vazios entre os pontos de um bordado, há frestas de sentido entre as palavras de um texto, há poros abertos no rendilhado-rede do pescador. $\mathrm{O}$ desenho e a fissura, a linha e o fio roto, o riscado e a ausência dele, o peixe preso e aquele que escapou. Por isso, além do fio, é constitutiva a falta dele na rede.

Buscamos, então, compreender de que modo as configurações do digital determinam e dão corpo a relação dos sujeitos com os sentidos sobre o corpo feminino, sendo o digital nosso recorte central de produção do nosso corpus analítico. Assim, procuramos, a compreensão do funcionamento do discurso digital no processo de produção de sentidos no espaço público, pelo modo de individuação dos sujeitos. Segundo Garcia e Sousa (2014, p. 87) a rede possibilita:

novas formas de individuação dos sujeitos, abre para a multiplicidade dos sentidos, sustenta desavenças, conflitos. A rede é um espaço heterogêneo, sustentado por relações de poder, que permite ao sujeito do século XXI ler temas que o afetam, dizer fatos que o incomodam, viver a possibilidade de uma sociedade menos sexista, violenta.

Deste modo, para essas autoras: "O ciberespaço permite a militância, permite a discussão de temas que afetam o funcionamento do espaço urbano. $\mathrm{Na}$ rede, confrontos surgem na tentativa de fundar outros discursos à sociedade, outras formas de socialização" (Garcia \& Sousa, 2014, p. 87). Para tanto, tomamos como objeto de análise a textualidade das obras de lambe-lambe na rede, cuja narratividade se constitui por um processo de metaforização do espaço urbano e do digital, sendo este processo, segundo Dias (2018), que determina a relação dos sujeitos com os sentidos em sua materialidade simbólica. Buscamos, como também apontado pela obra da autora, compreender como o simbólico, presente nas obras de lambe-lambe compartilhadas em rede, em sua relação com o político, estabelece sentidos para a conecticidade ${ }^{8}$. Assim, Dias (2018):

Define mobilidade não é necessariamente o mover-se no espaço, de um ponto ao outro, mas moverse em rede, entre nós. O que define a mobilidade é a conectividade. E essa conectividade tem a ver com laços sociais e com processos de identificação dos sujeitos. Estar conectado importa mais do que estar junto num espaço físico. Essa é a forma de significação da cidade contemporânea: conecticidade.

\footnotetext{
8 “A cidade contemporânea formada por redes de conectividade é a conecticidade" (Dias, 2018, p. 119).
} 
A autora ainda coloca que a mobilidade está estritamente ligada às mídias sociais, como o Facebook e o Instagram, que propomos trabalhar nesta pesquisa, na medida em que, por meio dele, é possível uma mudança na maneira dos sujeitos se relacionarem, modificando a maneira como o sujeito faz seus trajetos no espaço da cidade e se apropria dos conhecimentos tanto subjetiva quanto socialmente (Dias, 2018).

Ademais, a organização de uma sociabilidade e de novos laços sociais não se restringe mais à definição de fronteiras espaciais ou temporais, já que elas se estendem pelas redes sociais onde o laço se antecipa muitas vezes ao local físico do encontro. Com isso, há um deslocamento dos sentidos acerca da mobilidade que passa a ser considerada a partir das possibilidades de virtualização, tanto dos dizeres quanto dos sujeitos (Dias, 2018). Para Grigoletto, De Nardi e Schons (2011, p. 52) o:

processo de virtualização, a passagem do empírico para o discursivo não ocorre de forma neutra, e está atravessada por um novo modo de discursivizar, de se inscrever no discursivo qual seja: as determinações sócio-históricas e ideológicas decorrentes da emersão da rede na sociedade.

Dessa forma, no espaço virtual, há uma desterritorialização não só das informações, mas também das pessoas, produzindo efeitos tanto no real quanto no virtual. Ao encontro desse pensamento, Dias (2018) afirma que a "mobilidade não é necessariamente o mover-se no espaço, de um ponto ao outro, mas mover-se em rede, entre-nós e que o que define a mobilidade é a conectividade. Essa conectividade "tem a ver com os laços sociais e com os processos de identificação dos sujeitos" (Dias, 2018, p. 126).

Assim, hoje, com a entrada dos sujeitos nas novas tecnologias digitais, um sujeito pode pretensamente posicionar-se de diferentes modos, produzindo sentidos sobre si, e sobre o outro, tanto na rua como na rede. Considerando que é a ideologia dominante que convoca os sujeitos a ocuparem seus lugares pré-determinados na esfera social (Pêcheux, 1988 [1975]), observamos que a suposta liberdade na tomada de posição não ocorre sem consequências ao sujeito contemporâneo.

Esses gestos apresentam-se atualmente na rua, na rede e, no caso do objeto no qual nos debruçamos, o lambe-lambe, no entremeio entre essas duas instâncias, ou seja, nas relações de sentido que se estabelecem entre o sujeito e a língua, em condições de produção específicas a essa materialidade. Isso porque, nesse processo de constituição dos sentidos, e dos sujeitos, importam tanto os lugares que os sujeitos ocupam quanto as condições sócio-históricas e ideológicas em que estão envolvidos na produção do dizer (Pêcheux, 1988 [1975]). Sendo assim, os sentidos que inscrevem nos dizeres da/na rua não significam necessariamente da mesma forma quando veiculados na rede. 
Tomamos então os gestos discursivos materializados em discursividades, nas quais arte e poesia se tecem, quer na rua quer na rede; denominadas de lambe-lambe, que circulam na rua e na rede possibilitando o emergir não só do desejo d(o)e ser do sujeito-mulher, mas também o silenciamento desses sujeitos em sociedade. Nessa circunstância, não iremos pensálas como instâncias independentes, rua e rede, on e o off-line, mas sim como movimentos de um espaço em-comum no qual rua e rede se co(n)fundem, visto que o discurso que se materializa no poste também se faz presente nos posts, e o discurso que se materializa na rede também faz presença da rua.

Sendo assim, segundo Pereira (2018, p.23), "rua e rede, urbano e digital se relacionam na medida em que ambos nos constituem enquanto sujeitos. Os dois são lugares de significação e, portanto, políticos”. Ao tomarmos as obras de lambe-lambe, é importante nos atentarmos para o fato de que encontramos tais obras em muros de ruas públicas de grandes centros urbanos e, também, nas redes sociais. Em ambos os espaços, há um símbolo eletrônico próprio do digital, o @, que confere ao leitor uma direção, um endereçamento, de uma conta, em um determinado sistema eletrônico. Quando encontramos tal símbolo na cidade, percebemos que esse também constitui, de certa forma, o espaço físico, já que não é possível há uma inscrição ali de um arquivo digital.

Da mesma forma, o espaço da cidade também pertence a este arquivo, posto que ao vermos uma obra de lambe-lambe na rede também estamos vendo o espaço urbano onde essa também foi inserida. Com isso, "o ato de compartilhar atravessa a tela do eletrônico e preenche o muro, ressignificando tanto a rua quanto a rede" (Pereira, 2018, p. 24). Deste modo, de acordo com Dias (2018), podemos perceber que a discursividade da rede e da rua afetam a materialidade do lambe-lambe e produzem sentidos para um trabalho que pode ser pensado lado a lado, sendo essa possibilidade o elemento que faz ressurgir a potência do político.

Esse espaço em-comum "considera o político e, portanto, aquilo que é próprio das relações: a diferença” (Dias, 2018, p. 131). Assim, para recuperar a confiança no espaço público como lugar onde o político possa ressurgir, é necessária uma saída como forma de pensar a efemeridade das relações estabelecidas pelos seres no seio da vida social como forma de inibir esse "assalto a cidade" (p. 131), afastando-se do apagamento que ocorre pela violência derivada da anulação das diferenças que é própria do congelamento das relações sociais.

A essa violência, tomamos nesse trabalho a violência discursivizada na materialidade dos lambes, em que o funcionamento discursivo opera em dois eixos (inter e o 
intradiscursivo) e aponta-nos para a existência de um dizer anterior, já sedimentado de um enunciado sobre o corpo feminino do qual o sujeito não é origem. Ao ser retomado, esse funcionamento discursivo também garante a possibilidade de atualização de um dizer via a reformulação do enunciado, sendo esta re-atualização posta discursivamente nas obras que aqui estudamos. A partir disso, podemos considerar que esse espaço "em-comum”, que se dá entre a rede e a rua, possibilita a tensão entre o já dito e a possibilidade de dizer, proporcionando a retomada, a ressignificação e a atualização de um discurso, como também marcando a natureza do singular do dizer e dos gestos de resistência.

Assim, ao pensar sobre a tensão que se constitui nas relações sociais e se materializa na língua, pensamos que uma das formas da incidência da conectividade para incidência de sentidos outros (a serem) regularizados no seio social está no efeito discursivo das obras compartilhadas. Em nossa contemporaneidade, observamos a emergência de novas formas de enunciar e de circular os sentidos em/de nossa sociedade no espaço digital. Embora esse espaço esteja submetido a práticas de censura e silenciamento, esse presenta uma configuração que podem favorecer a formulação e a circulação de sentidos de denúncia e opressão. Esses sentidos encontram, no espaço digital (Dias, 2012), um lugar material de desenvolvimento de suas práticas de militância, das quais chamaremos cibermilitância.

Como cibermilitância entendemos o ativismo pela via do digital, que como bem aponta Moraes (2001, p. 1): "vem dinamizar as lutas das entidades civis a favor da justiça social num mundo que globaliza desigualdades de toda ordem". Ou seja, são sentidos que se somam no ciberespaço representam grupos e causas, sendo a Internet, um instrumento que facilita a intercomunicação de indivíduos e grupos a compartilharem panoramas e posicionamentos sobre o mundo.

\footnotetext{
Daí porque a organização em redes, dentro e fora da Internet, se revela inovadora. Elas facilitam a intercomunicação de indivíduos e agrupamentos heterogêneos que compartilham visões de mundo, sentimentos e desejos. Servem de estuários para a defesa de identidades culturais, a promoção de valores éticos e a democratização da esfera pública. (Moraes, 2001, p. 2).
}

Com isso, percebe-se a cibermilitância como um maneira de operar no funcionamento das práticas políticias em nossa sociedade, (re)produzindo diversos sentidos em rede. Conforme Chaves (2015, p. 42), a figura do militante como "porta voz" de um movimento político oferece um lugar a vozes dispersas e ao gesto particular e, muitas vezes, solitário da militância digital em que o "curtir" e "compartilhar" tornam-se modos de se significar na militância, isto é, gestos políticos de tomada de posição na luta por outros sentidos. Assim, essas vozes dispersas constitutivas de gestos de autoria também podem assumir um lugar de 
anonimato, inscrevendo-se a partir de um "nós" coletivo que desloca a prática política do individual para o grupal.

Faria (2016) afirma que também precisamos considerar o sócio-histórico e ideológico mais amplo da produção de um dizer em rede, pois temos características peculiares da contemporaneidade num contexto capitalista globalizado, cuja lógica de mercado é disseminada por vários âmbitos da vida diária não só no que tange à economia. Dessa forma, Faria (2016) assevera que temos enraizado também as hierarquias próprias do sistema em nossa língua, intrinsecamente ligadas às posições pré-determinadas ideológicas que os sujeitos ocupam no discurso. Sob esse viés, materializam-se, nas práticas sociais, relações de igualdade e subordinação por meio de uma luta de classes que se marca na e pela língua, produzindo os seus efeitos nos sujeitos citadinos. Conforme Orlandi (2010),

\footnotetext{
Como o Estado capitalista funciona pelo jurídico, esta forma sujeito funciona com seus direitos e deveres. O Estado, por sua vez, cumpre o seu modo de funcionamento, capitalista, individualizando o sujeito pela prática de suas Instituições e Discursos. E aí temos a forma sujeito individualizada, constituindo-se como um sujeito ao mesmo tempo livre, dono de sua vontade, e responsável. Liberdade e submissão, ser determinador e ser determinado, eis a contradição que o sujeito assume em seu próprio modo de funcionamento na ideologia capitalista (Orlandi, 2010, p. 3).
}

Embora os discursos de militância tenham se beneficiado da produção de espaços enunciativos ocasionados pela expansão da "sociedade em rede" que permitiram aos sujeitos outros espaços de dizer, a rede virtual também se constitui imaginariamente pelo efeito de completude com relação à informação (materializado na ideia do "tudo pode ser dito") e à acessibilidade (“a todos é permitido interpretar e dizer”), ou seja, ela se sustenta na ilusão de que, na rede digital de sentidos, todos os sentidos estão ali contemplados, assim como estabelece uma ilusão de há igualdade de condições, sendo essa uma lógica neo-liberal Segundo Romão, Leandro-Ferreira e Dela-Silva (2011, p. 15): “a web 'esconde' os seus limites; as suas bordas não se dão a conhecer enquanto 'gesto de catalogação"”.

Segundo as autoras, mesmo a internet tendo "desenquadrado sentidos estabilizados" ao tornar acessível "arquivos antes considerados marginais ou desimportantes" e que passaram a circular na malha digital, "abrindo campo para discursos antes com circulação restrita" (Romão; Leandro-Ferreira \& Dela-Silva, 2011, p. 12), ela possui seus limites que nem sempre são visíveis devido à ilusão de completude que os sujeitos podem ter.

Assim, o sentido de conexão compõe a forma como se estabelece discursivamente o laço social no espaço digital pelo efeito de afetividade, mas também pela formação de grupos e comunidades. Segundo Orlandi (2012, p 10), "o momento que o sujeito diz o que diz" é o ponto preciso em que o sujeito se posiciona como autor. Por isso há a importância da 
formulação, pois nela "há um investimento do corpo do sujeito presente no corpo das palavras" (Orlandi, 2012, p. 10). No entanto, como bem coloca Dias (2018, p. 33): "o que sustenta a formulação dos dizeres no digital é a sua circulação", sendo essa "o ângulo de entrada no processo de produção dos sentidos”. Para essa autora, ao reproduzir a obra de arte ou a fotografia, o artista a retira de seu aqui e agora, da singularidade de sua aparição. Ou seja, na rede o momento de aparição deixa de ser o momento em que o sujeito "diz o que diz" e passa a ser o momento em que os diferentes sujeitos em diferentes tempos passam a ter acesso àquele dizer.

De tal modo que, para essa autora, as formas de circulação e replicação no meio digital se tornam o próprio aqui e agora, singulares de sua aparição, sendo esta uma diferença fundamental entre a sua reprodução e as possibilidades de replicação e viralização de seu conteúdo com o digital.

Como já dito, objetivamos compreender neste capítulo se a especificidade técnica do dispositivo que nos propomos a analisar, no caso os perfis do Instagram, onde circulam e se formulam os sentidos sobre o feminino e seu corpo, afeta ou não a produção da linguagem dos discursos que analisamos, como também o modo como esses são produzidos e como circulam na sociedade.

Segundo Dias (2016), os três patamares colocados por Debray (1995): o físico (técnico), o semântico e o político estabelecem o meio material, onde se implica nossa análise, o momento da circulação dos discursos. Retomando Orlandi (2001), a pesquisadora desenvolve que a circulação dos sentidos é também um dos lugares de produção dos discursos, estando ao lado da constituição e da formulação.

Dias (2018) aborda a circulação como "ângulo de entrada" que proporciona eficácia ao sentido, já que, ao fazer circular um dizer em rede, objetiva-se a comunicação de um sentido sem a dificuldade posta pelas fronteiras de tempo e espaço. No entanto, a autora pontua que tal eficácia não estabelece garantias de historicização de um dizer, ou seja, tal fato não garante que venha a se estabelecer uma marca de sentido no político e na história, uma memória do dizer.

Assim, com a entrada do sujeito no contexto eletrônico, há um outro modo de retomada de sentidos já estabilizados e ou de formulação de novos discursos denominado memória metálica. Essa forma de memória refere-se às marcas de sentido produzidas pelas mídias e as novas tecnologias de linguagem, sendo esta forma de memória inserida na instância da circulação. 
Tal fato ocorre em rede, pois, segundo Pereira (2018), quanto mais atualizações um sujeito disponibilizar em seu perfil, maior será a sua visibilidade, uma vez que a circulação do seu dizer aumentará, alcançando, desse modo, mais interlocutores. Assim, a filiação do sujeito em uma rede de constituição de sentidos se estabelecerá pela atualização e circulação dos sentidos, ficando o nível da constituição a um plano secundário, o que não significa dizer, pois, que o sentido não estará também afetado e atravessado por já ditos e pela ideologia. Para Orlandi (2010, p. 9), uma das particularidades da memória metálica é:

ser horizontal, não havendo assim estratificação em seu processo, mas distribuição em série, na forma de adição, acúmulo: o que foi dito aqui e ali e mais além vai-se juntando como se formasse uma rede de filiação e não apenas uma soma. Quantidade e não historicidade

Dias (2014, p. 8) também discorre sobre esse movimento em rede afirmando que:

Diferente da noção de memória discursiva, que diz respeito à existência histórica do enunciado, a memória metálica concerne à existência técnica do enunciado. Na memória metálica, toda significação se dá no nível da atualização. Vemos que nesse caso, o ponto de partida para a construção dos sentidos não é a filiação do sujeito a uma rede de constituição do sentido, mas a uma rede de atualização técnica do sentido, uma vez que aquilo que se atualiza é o próprio registro. O já-dito armazenado que retorna sob a forma da atualização do registro de uma informação/dado, e não da formulação num intradiscurso, o que chamaríamos de uma atualização na forma da textualização da memória discursiva.

Dessa forma, vemos as redes funcionando como um suporte técnico que faz circular e atualizar o que já foi formulado em algum momento de nossa historicidade. A conectividade (im)posta nas redes sociais pressupõe a formação de um círculo de sociabilidade virtual que se comunica, formando conforme a autora, uma rede de dizeres de si e do outro que se entrelaçam, constituindo uma dispersão de outros. Em virtude disso, para dizer de/sobre si, o sujeito, ao publicar, marca uma posição que pode ser de ruptura com dizeres já cristalizados e/ou que segue a ordem do naturalizado e da evidência ideológica, endereçando esse discurso posto no post a um outro sujeito enquanto uma verdade absoluta. Este trabalho, materializado como um discurso no interior das práticas sociais, é afetado por essas condições de produção, é por meio desse contexto no qual nos sentimos convocados a depositar o nosso olhar e a nossa "escuta", além de observar o movimento da rua que também se manifesta em/na rede.

Para Dias (2018, p. 161), na memória digital: “a escrituração é o lugar onde esse resíduo pode ser observado. Não a escritura em si, mas a narratividade, pela maneira como a memória se diz, entre a captura do algoritmo e a liberdade do pensamento". Preocupa-nos, então, analisar onde se incide a discursividade, chamando-nos a atenção para a incidência da discursividade digital que se apresenta na textualidade das obras de lambe-lambe que circulam tanto na rua como na rede. Assim, para nós, a produção de sentidos inscrita nas obras de lambe-lambe em rede é afetada e determinada pelos sentidos de mobilidade das 
tecnologias contemporâneas, que, para Dias (2016), teriam como forma-material a conectividade. A mobilidade dos sujeitos artistas nas ruas da cidade torna-se importante, pois faz coincidir não só deslocamentos de sentidos dos flagrantes urbanos para os posts que circulam em rede, marcando ali a produção de sentidos afetadas pelo urbano, mas também carrega para o espaço urbano a discursividade do digital.

Considerando então que estamos analisando discursividades em que os sujeitos produzem sentidos na/pela materialidade digital, enquanto também os fazem circular pelas ruas da cidade, consideramos importante analisar tal fato a partir desse processo de constituição - multifacetada. Assim, buscamos nesse percurso compreender de que modo as configurações do digital afetam, determinam e dão corpo a relação dos sujeitos com os sentidos sobre o corpo feminino

Para Dias e Couto (2011), as redes sociais são ambientes virtuais onde os sujeitos se relacionam com a intenção de estabelecer uma espécie de socialização que se liga à formulação e circulação dos sentidos e dos conhecimentos. Esses locais de sociabilidade na rede se estabelecem a partir de diferentes condições de produção, já que, nas redes sociais, há outras formas de o imaginário reger o funcionamento dos sentidos. As autoras ainda colocam que o deslocamento causado pelas redes se configura a partir da produção do conhecimento.

Nas redes sociais, no caso dessa pesquisa, no Instagram, assim como proposto por Dias (2018), a constituição dos sentidos ocorre a partir de sua circulação, que possibilita o sujeito fazer circular textos, fotografias de obras, vídeos, eventos etc. O tipo de circulação que tal mídia produz se restringe ao círculo de pessoas que segue um determinado perfil, sendo estas vinculadas na mesma rede discursiva e ideológica daquele que o fez circular por um processo de identificação.

Os sujeitos, então, apropriam-se desses sentidos pela interpelação e apropriação dos sentidos. A identificação do sujeito pode ser pensada uma vez que o sujeito reproduz os sentidos inerentes à formação discursiva a que está interpelado. De outra forma, a contra identificação com determinados sentidos se realiza na medida em que o sujeito confronta determinados saberes inerentes àquela FD que o constitui como sujeito, a saber, sua formasujeito. A desidentificação, por sua vez, se marca pela negação daqueles saberes intrínsecos à sua forma-sujeito e se identifica com saberes outros, inerentes a outra forma-sujeito (Indursky, 2008).

Ao nos atermos às redes sociais como a materialidade, onde iremos analisar um dizer sobre o feminino e seu corpo, relacionaremos este instrumento, como bem pontua Dias (2013), com o desenvolvimento tecnológico de uma sociedade. Assim, tomamos as condições 
de produção sobre os sentidos sobre a mulher em rede com o movimento de produção de novos sentidos acerca desse sujeito, associado às relações históricas, sociais de produção de sentidos sobre o feminino. Os perfis nos quais nos debruçamos estão inscritos em um momento histórico em que há uma maior circulação e popularização dos sentidos de luta por novos sentidos sobre a mulher, tendo, então, essas condições sócio-histórico-ideológicas, afetado a constituição dos sentidos sobre o corpo da mulher em nosso corpus.

Segundo Hollanda (2018), é a partir de um movimento no espaço virtual que houve a transmissão de estilos de vida e narrativas de si que marcaram e ainda marcam uma nova forma de fazer política, que dilui as fronteiras entre o que é público e privado. Assim, a autora coloca-nos a pensar as redes sociais como um ponto fundamental de disseminação de lutas por novos sentidos sobre a mulher, contribuindo para a produção de novas subjetividades, conexões e tensões do ambiente virtual e não virtual. No entanto, Hollanda (2018) coloca também que as redes sociais têm seu funcionamento muitas vezes determinado por escolhas institucionais ou de grupo que incitam formulações específicas de difundir determinados discursos em rede, afetando, assim, os sentidos que ali circulam. Contudo, como bem já colocamos, para a $\mathrm{AD}$, há uma impossibilidade de controlar todos os sentidos, já que eles podem vir-a-ser outros na relação com o outro, em diferentes tempos e espaços onde determinados enunciados circulam.

Outro aspecto importante a ser considerado é a questão da acessibilidade aos discursos postos na rede, excluindo a população que não possui acesso à internet. Segundo Dias (2012), há um mito acerca da facilidade de acesso que, muitas vezes, instaura a ilusão de que a rede é para todos. Esse mito promove a ilusão de que os traços da censura e da hierarquia social são nesse espaço diluídos. Ou seja, há uma ilusão de que todos têm acesso à internet. Conforme Pereira (2018):

No Brasil, segundo dados divulgados pela Locomotiva Pesquisa e Estratégia no ano de 20178, $54,4 \%$ da população tem acesso à internet. A maior parte das pessoas excluídas do ambiente digital possui renda inferior a um salário mínimo e estão longe dos grandes centros urbanos. Na Região Norte, 55\% da população não está inserida no ambiente digital (Pereira, 2018, p. 23).

Em virtude disso, os dizeres em rede não perpassam a todos os sujeitos, pois muitos deles acabam ficando sem acesso às redes sociais devido a questões socioeconômicas. Ou seja, mesmo o meio virtual proporcionando-nos a fantasia de sermos muitos e de estarmos todos conectados, o acesso à rede não é para todos. Assim, podemos refletir sobre quais são os sujeitos que terão acesso aos movimentos de sentidos posto nas obras que se encontram em circulação nos perfis escolhidos por nós nessa pesquisa. Outro ponto que se destaca é que 
muitos também não terão acesso a esse movimento nas ruas, já que, muitas vezes, esses ocorrem em grandes centros urbanos.

De acordo Pêcheux (2011), ao analisarmos um discurso, não devemos fazê-lo como se analisa um texto em si mesmo, tomando apenas o seu conteúdo, mas sim analisá-lo a partir dos sentidos possíveis que surgem a partir de um estado particular de condição de produção de um dizer. Assim, em termos de condições de produção, é importante nos atentarmos em nossa análise que a escolha dos dizeres que nos propomos a analisar ocorre em uma formação social capitalista, em uma conjuntura sócio-histórico-ideológica determinada pelo avanço tecnológico, pela informatização da sociedade, pela mundialização das relações, entre outras, econômicas, financeiras, culturais, de um lado; e, por outro, pelas desigualdades sociais que não possibilitam o acesso de todos a esse avanço tecnológico.

Segundo Mittmanm (2011), as Tecnologias Digitais de Informação e Comunicação (TDIC'S) têm ocupado um papel importante no enfrentamento das forças constituintes de uma formação social em que, de um lado, mantém-se a forte saturação dos sentidos já préestabelecidos socialmente pela ideologia dominante e, de outro, uma intensa atuação de cidadãos, coletivos e movimentos sociais por meios alternativos como as TDIC'S. As tecnologias surgem então como espaço para circular a heterogeneidade do discurso, que, segundo o mesmo autor, atuam "fazendo circular vozes outras que não as parafraseadoras do discurso da ideologia dominante" (Mittmann, 2011, p. 120).

No entanto, como bem já levantamos, como o acesso à rede não é todo, e como os movimentos ocorrem muitas vezes nos grandes centros urbanos, quando na rua, ficam-nos dois questionamentos: Que sujeito-mulher é esse que estamos analisando nessa pesquisa? Quais sujeitos essas possíveis novas circulações de sentidos sobre a mulher e seu corpo podem afetar quando em rede? Segundo Dias (2016), na internet as fronteiras ainda existem e permanecem dividindo os sujeitos em espaços politicamente significados. Para a mesma autora, a mobilidade digital se organiza pelo acesso às redes. Assim, a ausência do acesso a essas redes estabelece linhas divisórias sociais importantes a serem consideradas nessa pesquisa. É importante considerar que este trabalho se utiliza de obras que circulam em um meio onde o acesso e a mobilidade digital são necessários. Portanto, trabalhamos com uma posição sujeito discursiva inclusa dentro dessa mobilidade digital. Ou seja, um lugar de dizer onde há a inclusão dos sujeitos dentro das TDIC'S.

A escolha por trabalhar uma materialidade que emite discursos sobre a mulher e sua luta por novos sentidos em sociedade ecoa justamente a discursividade da materialidade do eletrônico, já que realça, pela linguagem, um modo de estar na sociedade contemporânea e 
suas implicações político-ideológicas. Para Romão (2012), pensar o funcionamento discursivo da Internet "reclama uma reflexão sobre o político, visto que não ocorre sem escolhas por mostrar certos sentidos e silenciar outros, nem sem recortes de dizeres autorizados e outros impedidos de circular naquele lugar" (Romão, 2012, p. 114). Em outras palavras, olhar para esse modo de funcionamento é pensar os avanços e as rupturas em relação ao contraditório, retrocessos e emergências de dizeres já legitimados pelo poder.

Segundo Garcia e Sousa (2016), o ciberespaço é um lugar que abre a circulação para sentidos múltiplos, no entanto, um múltiplo permeado por relações de poder em que se permitem certos dizeres, mas interditam-se outros; ainda que de forma velada e sob a evidência ideológica de que tudo pode ser dito, certos sentidos tidos como indesejáveis são interditados, interrompidos e descontínuos.

A ocupação das ruas e das redes é uma das singularidades do movimento político e as redes digitais:

configuram-se como teias complexas, capazes de promover a articulação das relações políticas e sociais coletivas, muitas vezes a partir de iniciativas que, por sua vez, extrapolam uma dimensão particular ao se juntar a outras iniciativas, tecendo, assim, uma cadeia de ações comunicativas horizontais. (Romão, 2015, p. 68).

Sendo assim, tecer reflexões sobre de que modo as configurações do digital determinam e dão corpo à relação dos sujeitos com os sentidos sobre o corpo feminino nas obras de lambe-lambe que circulam em alguns perfis do Instagram é se ater ao fato de que sujeito(s) e sentido(s) que coloca(m)-se como autores dessas obras promovem uma articulação entre as relações do político e do social na rede. Esses sujeitos, interpelados pela ideologia, reclamam novos sentidos para o feminino e seu corpo, produzindo neles um efeito de evidência dos sentidos e a ilusão da transparência da linguagem. Logo, se analisarmos os modos de subjetivação que aparecem nesse discurso por meio da relação entre língua, sujeito e história, é também necessário contextualizar acerca da maneira como esse sujeito é interpelado pela ideologia, constituindo, assim, uma rede de sentidos que será posta no modo como o sujeito produz certos sentidos. Romão (2004, p. 71) ressalta que "o século XXI, nasce com marcas de silício nas veias, embalado pelo ideário de liberdade construído a partir da explosão das tecnologias de comunicação, especialmente que proporcionam velocidade, mobilidade e ubiquidade".

O sujeito é afetado por uma ilusão de ser e estar no centro do poder, da decisão de suas ações e da maneira como se posiciona no discurso (Orlandi, 2007). Já que “onde está a linguagem está a ideologia” (Orlandi, 2003, p. 34), buscamos, no decorrer de nossas análises, 
discorrer sobre o posicionamento discursivo (im)posto nas obras de arte de lambe-lambes que circulam na rede e que possibilitam entender o discurso sobre a mulher e seu corpo e o modo como se constrói um dizer sobre o feminino em/na rede.

Para Mittmann (2011, p. 119), a circulação de vozes na grande rede significante da rede faz circular discursos outros, que não coincidem com os dizeres do discurso da ideologia dominante, o que permite "a divulgação em grande escala de discursos de denúncias". Assim, existe a possibilidade da prática particular de militância na rede, cuja prerrogativa é a denúncia, em que deflagra gestos de pertencimento no discurso (im)posto na cidade e compartilha na rede, assim como possibilita pensar que o pertencimento só é possível de existir a partir de um posicionamento sócio-histórico e ideológico do sujeito em seu discurso.

Castells (2012) coloca que as diferentes manifestações tidas nos últimos anos são, em sua maioria, espontâneas em sua origem, tendo a indignação como motor. Para Dias (2018, p. 142), "o digital faz parte da significação do urbano e de suas tecnologias. As práticas dos sujeitos nas cidades são determinadas pelo digital", podendo ocorrer, como no caso que aqui estudamos, pela ordem do político, como é com o caso da metaforização dos sentidos da relação sujeito-mulher, rua e rede, processo esse que se dá pelo funcionamento das redes sociais e seus efeitos nos movimentos políticos e sociais.

Um ponto importante a ser desenvolvido é que, conforme aborda Galli $(2011 ; 2012)$, na rede eletrônica, os sujeitos se inscrevem em uma série de arquivos marcados por uma durabilidade, uma instabilidade, uma resistência e um tempo próprio, pois, na rede eletrônica, existe a fragmentação de um arquivo que tende compor uma grande estrutura que continuamente perde e renova informações quando está em constante interação com os sujeitos. Para tal, somos instigados a pensar, na esteira da autora brasileira, o ciberespaço como um espaço temporário, pois seu material passa por reformulações constantemente, não suportando, assim, a completude, já que nunca se fecha.

Como exemplo dessa relação, tomamos o fato verificado com os perfis de @lela.brandao (antigo@fridafeminista) @projeto.encontrarte). Esses perfis, atualmente, apresentam seus posts não se configurando mais apenas no formato de lambe-lambes, mas também por fotografias dos poemas ou ilustrações. Ryane Leão, dona do perfil @ondejazzmeucoração, que nesta pesquisa acaba não entrando como perfil no qual nos debruçamos, mas que também veiculava obras de lambe-lambe em seu perfil, lançou um livro após transitar na rua e na rede, publicando, em um primeiro momento, sua obra "Tudo nela brilha e queima" e, em um segundo momento, uma segunda obra, a "Jamais peço desculpas por me derramar: poemas de temporal e mansidão". Por meio da publicação dessas obras, ela 
demonstrou que o ciberespaço é um espaço temporário e que os materiais passam por reformulações constantemente.

Podemos também pensar o potencial que o arquivo digital tem de deslocar-se da tela para o contexto impresso, sendo interessante refletir sobre os deslocamentos que a tecnologia produz. Pela força do Instagram, alguns escritores que fazem circular suas poesias no meio digital, principalmente nesse suporte, passaram a serem apelidados de Instapoetas. Segundo Ramos e Martins (2018, p. 118):

\footnotetext{
No âmbito artístico, especificamente o da literatura, as conexões entre virtual e físico se repetem. Autores e obras já consagrados pela crítica tradicional migram para o ciberespaço, instalando-se em sites e redes sociais digitais, como Blog, YouTube, Facebook, Twitter, Instagram, entre outras. Também nesses espaços, usuários comuns são consagrados escritores e publicam suas primeiras obras virtuais e físicas -, passando pelo crivo da crítica contemporânea - o público - e estabelecendo contratos com editoras. É assim que o Instagram se tornou para muitos uma plataforma de publicação, compartilhamento e leitura de conteúdos poéticos, formando um público de leitores e chancelando a figura de autores. Ainda que sua proposta inicial se fundamentasse no compartilhamento de fotografias, o constante uso do Instagram assegurou à palavra o seu espaço.
}

A circulação das obras de lambe-lambe, mais especificamente o corpus que aqui nos colocamos a estudar proporciona, através da circulação, a constituição e a visibilidade de sentidos sobre o corpo feminino, fora das discursividades da denúncia de padrões estéticos dificilmente alcançáveis e segregadores, além de sentidos de uma cultura de violação do corpo feminino, como se este não pertencesse às mulheres, mas fosse um objeto de uso "público". Nas obras, vemos então sentidos sobre corpos femininos circulando e resistindo a estes tipos de opressão, sejam elas estéticas ou físicas.

Além disso, mesmo não havendo uma regulação de um dizer nos espaços da rua e da rede, regula-se o encontro com o furo da ideologia dominante a partir das obras desses perfis, permitindo-nos, então, romper com um sentido estabilizado sobre o corpo feminino. As obras também operam como redes de memória a fim de estabilizar um novo dizer, um novo sentido, uma memória outra, sobre o corpo da mulher na atualidade, possibilitando, assim, novas práticas sociais. Desta maneira, essas contas interferem no modo como os sujeitos se encontram e estabelecem relações, estando ligados às atuais condições de produção da contemporaneidade, produzindo novos sentidos sobre o feminino e seu corpo. 


\section{O MÉTODO DISCURSIVO E SUA ESTRUTURA METODOLÓGICA}

Figura 7 - Obra da artista visual brasileira Anarkia Boladona

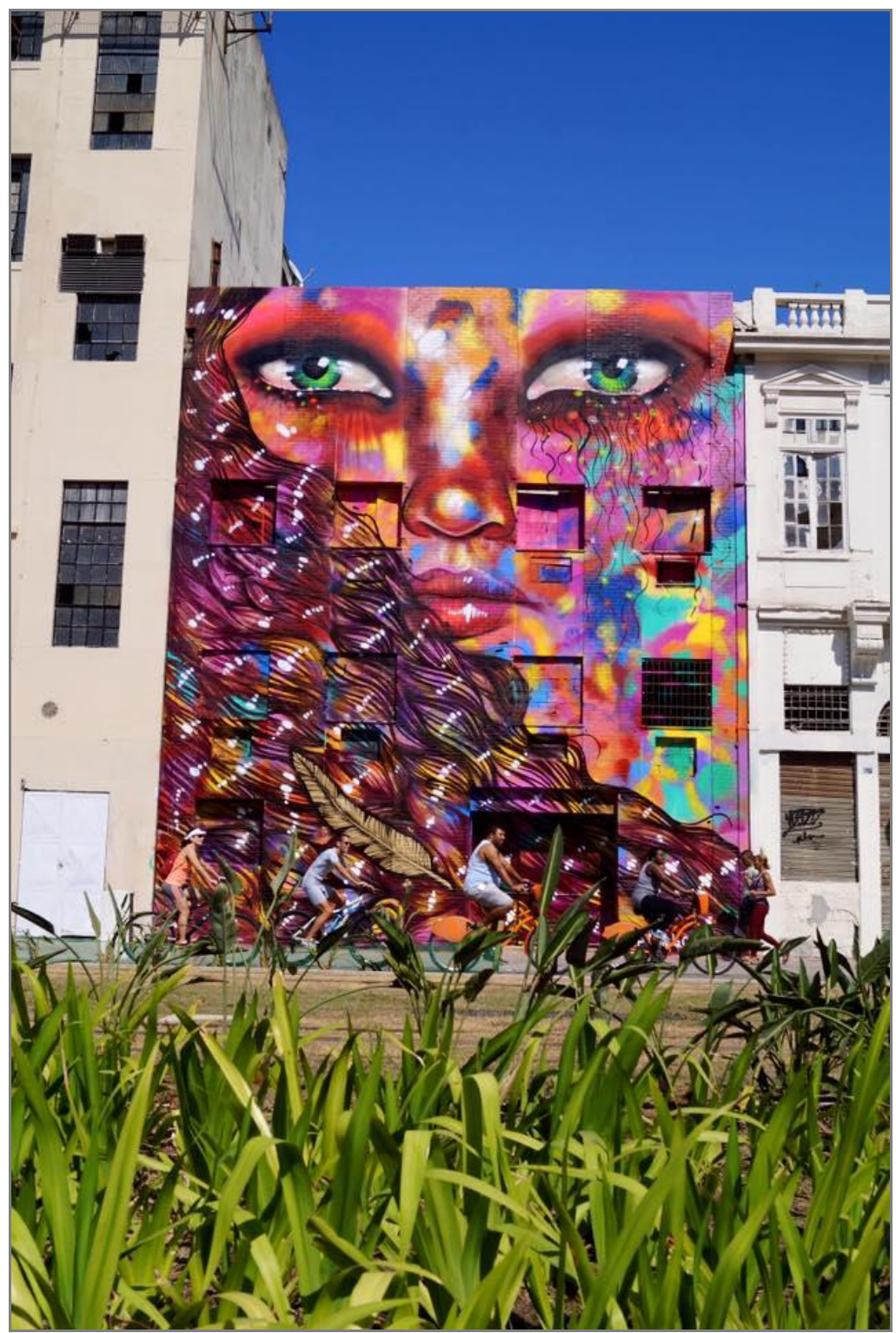

Fonte: https://naomekahlo.com/5-grafiteiras-que-voce-precisa-conhecer/

quando minha mãe abre a boca para conversar durante o jantar meu pai enfia a palavra silêncio nos seus lábios e diz que ela nunca deve falar com a boca cheia foi assim que as mulheres da minha família aprenderam a viver com a boca fechada 
Na presente seção, foi delineada a metodologia utilizada nesta pesquisa, bem como o local onde ela se encontra dentro das metodologias de pesquisa. Colocamos aqui em discussão um enquadramento não-todo da $\mathrm{AD}$ dentro das metodologias, sendo tal fato imprescindível para a compreensão do movimento/método do analista do discurso em sua prática analítica.

\subsection{Considerações metodológicas: o lugar da Análise do discurso nas metodologias de pesquisa}

Em um estudo científico, é importante analisar se o teme estudado está inserido em uma atividade de pesquisa teórica ou empírica, para que, assim, o pesquisador possa selecionar o melhor método para sua investigação. Para Alvarenga e Rosa (2003), o método nada mais é que uma organização dos caminhos que o pesquisador faz para atingir os objetivos de seu trabalho. Assim, no campo científico empírico, existem dois métodos considerados principais para se abordar uma pesquisa: o quantitativo e o qualitativo. Sobre o método quantitativo, Cozby (2003) enfatiza os dados estatísticos que utilizam os números obtidos como forma de compreender os fenômenos e as variáveis estudadas, já o método qualitativo configura-se no que Bogdan e Biklen (1994) afirmam: uma metodologia de investigação responsável pela descrição, pela indução, pela teoria fundamentada e pelo estudo das percepções pessoais.

Nesta investigação, será utilizado o aporte teórico e metodológico da Análise de Discurso Francesa, que tem suas aproximações e suas rupturas com o âmbito das pesquisas qualitativas. De natureza interpretativa da linguagem, a AD tem como objetivo compreender a maneira como um objeto simbólico produz sentidos, buscando, também, escutar outros que são produzidos e silenciados numa rede discursiva. Ela não busca a descrição de um dizer, mas o seu contrário, apontar uma opacidade da linguagem. Ademais, a AD não trabalha com a neutralidade do dizer de percepções pessoais, mas aponta o fato de que nenhum sujeito está neutro de sentidos, nem mesmo o sujeito pesquisador, já que ele também está inserido em uma rede discursiva que é afetada pelas relações sócio-históricas e ideológicas, além do inconsciente.

Assim, para a AD, a linguagem tem potencial de causar deslizamentos que nem sempre permitem generalizações ou instituições identificáveis, podendo, então, surgir sentidos inesperados que podem funcionar como óbvios para o sujeito que os enunciou, tornando-se, desse modo, inviável encontrar um lugar para a teoria no interior da pesquisa quantitativa, já que esses dados não aparecem brutos, o que torna o deslizar da linguagem inviável para essa 
metodologia de trabalho. Dessa forma, optar pela AD francesa como referencial teórico para analisar as obras de lambe-lambe implica abandonar o conceito de transparência na linguagem e procurar sua relação com as condições de produção da obra/dizer, atentando-se em uma busca por dizeres e silenciamentos materializados no corpus da pesquisa. Tal movimento é o que o analista do discurso nomeia por investigar os deslocamentos discursivos, fonte de nossa reflexão. Nesse sentido, o seu método não se centra no sujeito, mas no modo como se estabelece a inscrição de um discurso na história, a posição discursiva que esse sujeito estabelece no social quando irrompe o seu dizer, bem como o atravessamento do processo de interpelação ideológica no discurso. A concepção discursiva de sujeito refere-se a uma posição ocupada a partir da história e da ideologia pelas quais ele foi interpelado, para que a partir da sua posição irrompa a produção de sentidos diversos. Logo, é a partir da linguagem que o sujeito se constitui, é, também, nela que ele deixa as marcas desse processo ideológico.

Portanto, analisar as obras artísticas de lambe-lambe pelo viés discursivo não consiste em apenas observar um padrão pré-estabelecido para o pesquisador, mas de descrever as práticas discursivas que permitem que determinados sentidos irrompam em determinadas condições de produção. Ou seja, trata-se de uma teoria que se reformula a todo instante a partir dos lugares de inscrição do sujeito e o objeto por ele analisado.

Conforme Lagazzi (1988), a delimitação do corpus só acontece com a sua própria análise. O recorte dos dados é realizado de modo definido pelas condições de produção. Mesmo que o analista tenha certos objetivos e princípios teóricos, ele não foge a essa regra, estabelecendo, com isso, um campo discursivo de referência com sucessivas restrições de um "universal discursivo" que visa uma homogeneização do material para obter sequências discursivas que serão submetidas às análises. É nesse processo de pretensa homogeneização que atuam as condições de produção. Cabe ressaltar, ainda, que

O fato das condições de produção indicarem procedimentos de constituição do corpus não significa que elas se encontrem formuladas à priori. Apesar de algumas condições de produção que nós diremos 'gerais' agirem desde a coleta dos dados, elas se colocam quase que implícitas no objetivo da análise. Só simultaneamente ao corpus é que as condições de produção ('gerais' e 'específicas') podem ser fixadas. É uma explicitação mútua, que configura um primeiro momento da análise discursiva (Lagazzi, 1988, p. 59).

Neste trabalho, observamos o fato de uma condição de produção que se desenvolve no entremeio do digital e do urbano, atravessando a relação do sujeito com os sentidos. Tal fato, como já vimos no capítulo anterior, ocorre devido à formulação da poesia do lambe (corpus dessa pesquisa) se estabelecer pela influência do digital e da rua, já que, nas obras que selecionamos, propomos uma relação de um dizer colocado no poste com sua existência em 
perfis do Instagram. Isso ocorre pelo fato de as obras serem acompanhadas de um @, característica desse universo digital, como também, pela rua estar também significada nos materiais dos posts ao aparecer aquela obra posta em um poste de rua. Há também a marca da cola no virtual, marca de um outro discurso (o da rua), estando aí a memória da colagem de um cartaz. Dessa forma, verificamos que a relação rua-rede atua como uma mesma rede, na qual arte e poesia se tecem, sendo essa uma condição de produção importante a ser considerada no processo de análise e, por consequência, um dos nossos objetivos.

Sobre a posição do pesquisador, aqui nomeado de analista do discurso, Orlandi (1990) distingue alguns níveis existentes no olhar de um leitor: a inteligibilidade, a interpretabilidade e a compreensão. O primeiro refere-se à decodificação do texto, com a significação reduzida ao ponto de vista da gramática. A partir do nível da interpretabilidade, um sentido é atribuído ao enunciado e ao contexto linguístico e enunciativo, um certo sentido, sendo então considerado o nível em que: "a leitura produzida pela relação de um autor específico a um leitor determinado. Este fixa e é fixado por um certo sentido previsto nas condições de produção" (Orlandi, 1990, p. 174). No entanto, é a partir do nível da compreensão que se apreendem as várias possibilidades inscritas num texto, com assimilações dos processos de significação que se inserem ali em conjunto com a historicidade do sujeito e do sentido. A posição do analista do discurso é a de problematizar sua própria posição, “o sujeito que produz uma leitura a partir de sua posição, interpreta. $\mathrm{O}$ sujeito-leitor que se relaciona criticamente com sua posição, que a problematiza, explicitando as condições de produção de sua leitura compreende" (Orlandi, 2007, p. 116). Tal organização é flagrada nas marcas linguísticas que materializam tanto o dizer analisado quanto do próprio analista.

Assim, o analista do discurso considera sua própria interferência ao invés de negá-la, como ocorre em pesquisas de teor conteudístico, nas quais os resultados geralmente são tabelas de dados estatísticos. Para a $\mathrm{AD}$, não é possível chegar a um discurso científico "puro", isento de ideologia, já que o discurso é a forma material da ideologia. Por conseguinte, é impossível a existência de um pesquisador que se limite ao papel de simples observador frente ao objeto de seu trabalho, descomprometido de suas crenças. Ou seja,

Dessa forma, devemos ter o cuidado de não incorrer nem ao extremo da pura subjetividade, do 'achar' que é rebatido por um 'achar' contrário, sem procedimentos concretos que possam solidificar uma análise, nem no outro extremo dos modelos prontos, definidos anteriormente a seus objetos, que podem nos levar a uma análise apenas conteudística, onde o que temos a dizer serve apenas para comprovar uma conclusão pré-estabelecida (Lagazzi,1988, p. 51).

Na Análise do Discurso, há um aporte teórico e metodológico sólido capaz de analisar um discurso em sua relação com suas condições de produção, não sendo, assim, apenas uma 
inferência do conteúdo ou um estabelecimento de análise a partir da opinião do próprio analista sem qualquer relação com o meio social que aquele dizer foi constituído. Essa abordagem teórico-analítica permite que o analista, atravessado pela história, pela ideologia e pelo seu inconsciente, reflita sobre o cenário de sua época, sendo uma proposta de ruptura com os esquemas de pesquisa rígidos existentes.

A metodologia da Análise do Discurso permite uma abertura a múltiplas possibilidades de análise, mas sempre se ancorando em uma teoria específica. Com efeito, o analista do discurso depende de qual recorte teórico-analítico realizará para delimitar o caminho a percorrer em seu processo de análise. Segundo Orlandi (2007) uma análise discursiva parte sempre, em primeiro lugar, de um olhar específico, que é determinado pelo quadro epistemológico proposto por Pêcheux \& Fuchs, em 1975, na construção da AD, unindo o histórico ao linguístico em uma teoria que é atravessada pela teoria Psicanalítica. Assim, e a partir desse quadro, enquanto estudiosos do discurso, não efetuamos uma descrição do texto, como são realizadas as análises de conteúdo, mas sim estabelecemos uma teorização sobre o discurso, tomando o texto em sua unidade linguística em funcionamento, a partir de suas condições de produção e leitura.

Percorremos, assim, cada texto, relacionando-o com a história, pensando o linguístico em sua relação com o ideológico e com o inconsciente, estando cientes de que somos afetados por ambos. Nesse caminho, optar pela AD francesa como referencial teórico implica abandonar o conceito de transparência na linguagem e procurar sua relação com as condições de produção da obra/dizer, atentando-se em uma busca por dizeres e silenciamentos materializados no corpus da pesquisa. Tal movimento é o que o analista do discurso nomeia por investigar os deslocamentos discursivos, fonte de nossa reflexão.

\subsection{Condições de produção do corpus de pesquisa}

Contemporaneamente, o destaque dado à temática do feminino e aos sentidos que circulam sobre ele em sociedade tem permitido reflexões e reatualizações de sentido importantes. Esse movimento vem sendo cada vez mais presente através do uso das tecnologias que, a partir da conectividade existente hoje, tornou-se uma característica imprescindível para a mobilidade de informações e discursos na atualidade, já que, graças a ela, foi e ainda é possível que movimentos urbanos contemporâneos e formas de organização do espaço e de instituições se encontrem a fim de possibilitar novos processos de ressignificação dos sentidos. 
Devido à impossibilidade de estudar todos os espaços ofertados no ciberespaço, compreendemos a importância de delimitarmos bem o nosso corpus de pesquisa e as condições de produção para chegarmos até ele. Assim, nesta seção, iremos discutir a estrutura metodológica que utilizamos nesta pesquisa para chegarmos à constituição do nosso corpus. Como já vimos, a AD permite ao analista - atravessado(a) pela história, ideologia e inconsciente - que reflita e analise a respeito do cenário de sua época. $\mathrm{O}$ analista do discurso opera então a partir de um material linguístico - o arquivo e o corpus (material bruto) - para chegar ao seu objeto discursivo, transformando o material da superfície linguística em um objeto teórico capaz de ser analisado, e a partir dele, compreender como os sentidos são produzidos nesse material, sendo esse o primeiro gesto de análise de um pesquisador da AD. Sendo assim, observamos que nosso objeto teórico é o discurso, mas nosso objeto de análise são as postagens.

Orlandi (2007, p. 77) aponta que nessa fase o analista procura ver no material bruto sua discursividade e "constrói um objeto discursivo em que já está considerado o esquecimento número dois (da instância da enunciação), desfazendo assim a ilusão de que aquilo que foi dito só poderia sê-lo daquela maneira". A autora afirma, ainda, que nesse momento de análise torna-se fundamental o trabalho com as paráfrases, sinonímia, relação do dizer e não-dizer, etc. Esta etapa (etapa 1) prepara então o analista para que possa começar o processo de vislumbramento das configurações das formações discursivas que estão dominando a prática discursiva em questão. Esta etapa irá tornar visível o fato de que, ao longo do dizer, formam-se famílias parafrásticas relacionando o que foi dito com o que não foi dito, com o que poderia ser dito etc. Estes outros dizeres aí observados dão as limitações das formações discursivas que intervêm, fazendo as palavras significarem de maneira x ou y. (Orlandi, 2007, p. 78).

Procuramos, então, proposições que fazem a significação de mulher e corpo serem uma coisa e outra; serem x e y, serem e não serem, pois são atravessadas por uma série de equívocos (no sentido de não terem seu significado claro, não de "engano") tendo seu modo de existência regido pela forma como são faladas. A questão que fica para o analista do discurso é, justamente, a maneira como os significantes mulher e corpo são falados, sendo a marca de sua existência na língua e na História. Põe-se, então, a discursividade como estrutura e acontecimento no ponto de encontro de uma atualidade com uma memória (Pêcheux, 1983), impondo ao mesmo tempo uma prática de leitura e interpretação sobre a forma como o corpo da mulher já foi dito com aquilo o que é dito, assim como aquilo que não é dito sobre ele. Estabelecemos, então, um gesto interpretação que considera a materialidade da língua, 
exposta ao equívoco, lembrando que "[...] todo enunciado é intrinsecamente suscetível de tornar-se outro, diferente de si mesmo, se deslocar discursivamente de seu sentido para derivar para um outro [...]" (Pêcheux, 1983, p. 53), na relação com a materialidade da História, tomada como uma disciplina de interpretação e não uma física de tipo novo, ou seja, que não funcione "[...] como transcendental histórico, grade de leitura ou memória antecipadora do discurso em questão [...]" (Pêcheux, 1983, p. 56). Dupla perspectiva que, para o analista de discurso, desdobra-se no batimento descrição/interpretação, abrindo o discurso para a possibilidade de deslocamentos na História.

Orlandi (2007) discorre ainda sobre um segundo gesto a ser realizado pelo analista (etapa 2). Partindo já do objeto discursivo (etapa 1), o analista se incide num processo de análise procurando relacionar as formações discursivas (FD) com as formações ideológicas (FI). É importante considerar que as FD se delineiam no jogo de sentidos observado pela análise no processo de significação (paráfrase, metonímia, etc.) enquanto as FI regem essas relações. É, então, nesse momento, que o analista do discurso alcança a constituição dos processos discursivos responsáveis pelo efeito de sentidos produzidos em determinado material simbólico, cuja formulação serviu de ponto de partida para o analista. (Orlandi, 2007, p. 78).

Nesse contexto, o pesquisador deve levar em conta a forma como o objeto simbólico produz sentido, ou seja, seu funcionamento discursivo para, a partir disso, construir um percurso de interpretação. A interpretação é o "sentido pensando-se o co-texto (as outras frases do texto) e o contexto imediato" (Orlandi, 2007, p. 26), e a compreensão de um funcionamento discursivo comporta analisar como as interpretações funcionam em um texto. De tal modo, “interpretar não é atribuir sentido, mas expor-se à opacidade do texto, ou seja, é explicitar como um objeto simbólico produz sentidos" (Orlandi, 2010, p. 24).

Pensando, então, sobre o trabalho de interpretação proposto por Orlandi (2010), desenvolver uma pesquisa em Análise do Discurso é trabalhar com a interpretação de forma a considerar as posições discursivas e sua inscrição na língua durante o processo discursivo. Para Bastos (2018, p. 16), um gesto de interpretação analítico na AD se baseia em:

[...] escutar os discursos, nos quais as posições discursivas e sua inscrição na língua são consideradas e observadas nos processos discursivos. Da língua, o analista do discurso atua com a materialidade linguística, escutando e analisando os indícios do discurso, no qual marcas, ruídos e silêncios afetam essa relação. Na e pela língua é que temos as condições de atuar com o material discursivo, esse é o nosso corpo de observação, possibilitando o trabalho com os efeitos de sentidos produzidos. 
Com isso, a AD não trabalha e nem objetiva encontrar um sentido único para um discurso, não pretende apreender e controlar um todo da interpretação. Ela está sempre atuando em uma tentativa de relacionar um objeto simbólico a sentidos pré-construídos, tomando então à língua em sua imprevisibilidade e em sua relação com a história. Assim, para a $\mathrm{AD}$ : "não há verdade atrás do texto. Há gestos de interpretação que o constituem e que ele, com seu dispositivo, deve ser capaz de compreender" (Orlandi, 2007, p. 26).

Ainda com Bastos (2018, p. 40), vemos que "o texto não é considerado dado, mas sim, fato discursivo, não é o interesse final do analista do discurso, mas é o ponto, a unidade que propicia que ele chegue ao discurso e possa trabalhar”. Cada material de análise exige que seu analista construa um dispositivo individual para este, já que cada um proporciona suas práticas de leitura para o trabalho de interpretação. Segundo Orlandi (2007, p. 27), "o que define a forma do dispositivo analítico é a questão posta pelo analista, a natureza do material que analisa e a finalidade da análise". Sendo, então, este fato propiciador de uma análise que não seja igual a outra, uma vez que há a possibilidade de trabalharmos a partir de conceitos e recortes diferentes.

Para Lagazzi (1988), o fazer científico da AD não deve ser concebido enquanto neutro, o que invalidaria a pesquisa em $\mathrm{AD}$ pelas metodologias tradicionais, pelo contrário, de certa forma, isto a faz ainda mais "científica", pois o pesquisador, não se esquiva de reconhecer que ele mesmo faz parte de um processo de interpelação ideológica. Assim, ao trabalharmos com um discurso, temos que considerar a relação que os interlocutores mantêm com a formação ideológica que perpassa cada dizer, assinalada no e pelo funcionamento discursivo, abrindo condições para que o analista questione o que é apresentado como evidente no discurso (Orlandi, 2003).

Ainda de acordo com Lagazzi (1988, p. 61), “a partir das marcas linguísticas que se sobressaem, configurando as pistas para a análise, é que começarão a delinear o caminho que levará o analista ao processo discursivo, possibilitando-lhe explicar o funcionamento do discurso". Assim, o trabalho de análise se realiza na busca por compreender os efeitos de evidência de sentido que são produzidos no decorrer do funcionamento da linguagem, procurando expor a opacidade na produção dos sentidos em um discurso. Orlandi (2012, p. 27) desenvolve que o objetivo do analista "não é descrever nem interpretar mas compreender - isto é, explicitar - os processos de significação que trabalham o texto; compreender como o texto produz sentidos através de seus mecanismos de funcionamento" (Orlandi, 2012, p. 27). Deste modo, interessam à $\mathrm{AD}$ as "propriedades internas ao processo discursivo: condições, 
remissão a formações discursivas, modo de funcionamento" (Orlandi, 2007, p. 86), como também a maneira como se realiza a produção de sentidos no corpus do pesquisador.

Para clarificar as etapas de desenvolvimento deste trabalho, retomamos os dizeres de Minayo (2010) sobre as três dimensões que um projeto de pesquisa deve abranger, na sua etapa de fase exploratória, que, de certo modo, compõem esse momento de reflexão: a) técnica: como definir o objeto e escolher os instrumentos; b) ideológica: a neutralidade da investigação científica é um mito; c) científica: articula as duas anteriores e ultrapassa o senso comum por meio do método científico. $\mathrm{O}$ item $\mathrm{b}$ foi explanado acima ao comentarmos as características metodológicas da $\mathrm{AD}$ e a posição não neutra do analista com relação ao corpus, enquanto o item a é o que buscamos esmiuçar nesta seção. Resta-nos, então, demonstrar o caminho metodológico nesta pesquisa.

Como já dito, a AD é uma disciplina de entremeio e, de acordo com Petri (2013), seu dispositivo teórico e metodológico deve ser construído a partir de um movimento pendular entre teoria e análise. Consideramos importante estabelecer delimitações discursivas estruturais à apresentação dos conceitos de arquivo, corpus e recorte discursivo dentro da perspectiva da $\mathrm{AD}$, já que tais noções estão atreladas à compreensão do nosso método discursivo.

Para Orlandi (2010a), o analista do discurso age primeiramente sob o material linguístico bruto, sendo este o arquivo e o corpus, para, posteriormente, seguir para um aprofundamento do material, resultando no objeto discursivo, que seria a primeira etapa de uma análise, quando se é possível analisar o desenho das primeiras formações discursivas presentes na organização do material. Em uma segunda etapa, o analista, partindo de seu objeto discursivo, passa a considerar as relações desses com as formações ideológicas, possibilitando alcançarmos o processo discursivo. Tal etapa também permite que o analista dispense os demais materiais ali reunidos para trabalhar com o sistema de paráfrase e sinonímias que exercem um funcionamento em determinada formação discursiva, propiciando reflexões sobre o conjunto de materiais com os recortes discursivos.

Para efeito ilustrativo, apresentamos as figuras 1 e 2 que elaboramos para melhor compreender esta inter-relação. No entanto, é importante não se esquecer que a construção do corpus de pesquisa não deve ser separada da teoria, sendo o movimento metodológico da AD pendular como bem apontado por Petri (2013) 
Figura 8 - Material linguístico

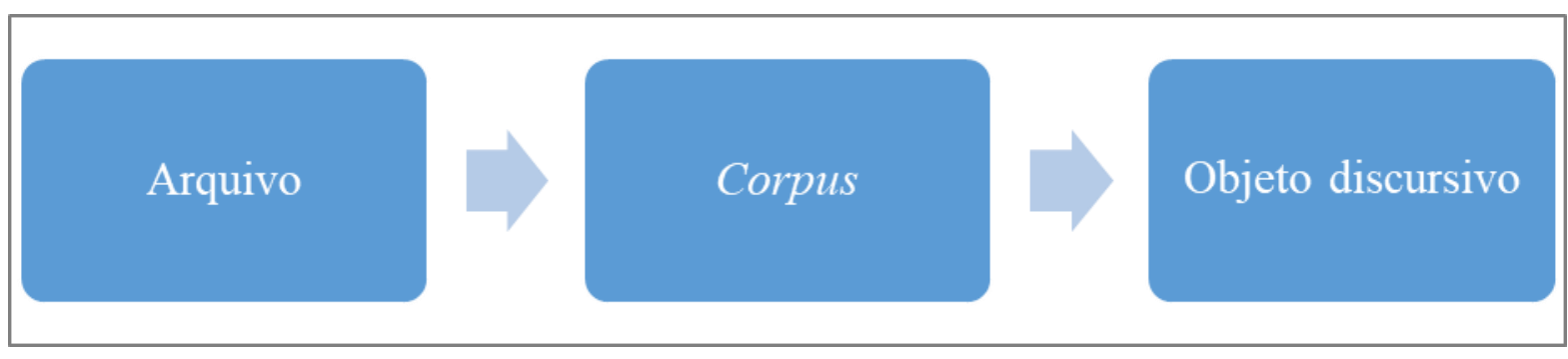

Fonte: produção da própria autora.

Figura 9 - Aprofundamento do material

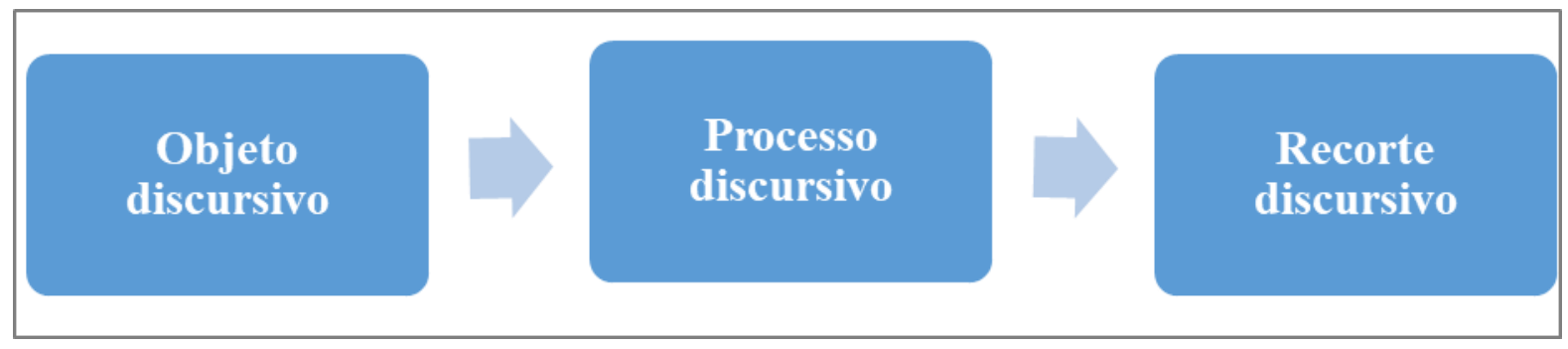

Fonte: produção da própria autora.

Assim, segundo Orlandi (2010a), é por meio de um corpus bem delineado e selecionado a partir de um arquivo que o analista do discurso tem acesso aos recortes discursivos de sua pesquisa, e essa relação é importante de ser pormenorizada quando o pesquisador se propõe a descrever os passos que estabeleceu em sua análise. Pensando a relação do analista com o arquivo no qual esse pesquisador vai se utilizar, é importante considerar que para a $\mathrm{AD}$ o arquivo é:

O arquivo não é visto como um conjunto de "dados" objetivos dos quais estaria excluída a espessura histórica, mas como uma materialidade discursiva que traz as marcas da constituição dos sentidos. O material de arquivo está sujeito a interpretação e, mais do que isso, à confrontação entre diferentes formas de interpretação e, portanto, não corresponde a um espaço de 'comprovação', onde se suportaria uma interpretação unívoca. (Nunes, 2005, p. 2)

Mittmann (2005, p. 1) resgata este conceito - cunhado por Pêcheux - afirmando que:

Diante do universo de discursos passíveis de análise, traçamos um primeiro recorte de um arquivo, definido por Pêcheux (1997) como 'campo de documentos pertinentes e disponíveis sobre uma questão'. Deste, delimitamos um campo discursivo de referência a partir de uma sequência de restrições.

Já para Guilhaumou e Maldidier (2010, p. 162):

[...] todo arquivo é identificado pela presença de uma data, de um nome próprio ou de uma chancela institucional; ou, ainda, 'pelo lugar que ele ocupa em uma série'. Essa identificação, porém, para os autores, diz pouco sobre o funcionamento do arquivo uma vez que, em concordância com Pêcheux, 'o 
arquivo não é um simples documento no qual se encontram referências; ele permite uma leitura que traz à tona dispositivos e configurações significantes'.

Assim, podemos considerar arquivo como um agrupamento de documentos já relacionados com um tema, podendo, deste modo, pensar que, de alguma maneira, ele já sofre certa organização, estando, portanto, organizado por uma (re)leitura. Porém, partimos de uma perspectiva teórica que defende a não-evidência de documentos reunidos em um arquivo, ocasionando, assim, que o sujeito pesquisador se posicione a partir de uma relação particular com seu arquivo, já que a leitura que ele faz dos documentos ali reunidos não é a única possível, mas, sim, uma entre tantas existentes.

Desta maneira, partimos de nosso arquivo não o tomando como um espaço de saturação de certos sentidos, enquanto uma verdade a ser descoberta sobre o feminino e seu corpo, mas como um espaço que inscreve efeitos de sentidos em um determinado contexto sócio-histórico-ideológico. Sabemos também que o arquivo não deve ser visto como um objeto neutro, mas sendo um espaço capaz de produzir o acesso aos dizeres que retratam como e a forma com que determinada questão é desenvolvida em um período específico. Segundo Romão, Ferreira e Dela-Silva (2011, p. 11), o arquivo “inscreve efeitos de saturação de certos sentidos a partir de instancias de poder, quais sejam, poder dizer, poder ordenar, poder fazer circular e poder produzir ressonâncias”. Assim, é possível apreender a inscrição do político no/pelo arquivo, já que ele deve ser abarcado pela sua espessura histórica. Portanto, o imaginário de que uma mulher, ao dizer de si na rede, está em uma posição de poder é ilusória, já que, ainda hoje, as mulheres lutam por representações positivas e de liberdade sobre si no espaço público.

Além disso, segundo Romão (2005), um arquivo na estrutura digital nos traz a ilusão de que a falta não existe no processo de armazenamento, sendo tal fato um mito. Além disso, "o que se mostra na internet é uma soma de arquivos eletrônicos que foram recortados, selecionados e manipulados anteriormente a sua exposição, que instalam, no espaço dizível, sentidos que aparecem disponíveis a todos" (Romão, 2005, p. 56).

$\mathrm{O}$ arquivo relacionado ao feminino na rede hoje é extremamente vasto. Alertados da impossibilidade de nos debruçarmos no estudo de todos os espaços ofertados no ciberespaço, entendemos a importância de selecionarmos alguns espaços para observação e análise, para melhor compreender os movimentos de sentido que se inscrevem no digital sobre a mulher e seu corpo. Foi pelo acesso a inúmeros espaços discursivos, disponíveis no ciberespaço que traziam sentidos sobre a mulher e seu corpo em nossa contemporaneidade, que chegamos ao corpus de nossa pesquisa. Corpus que se apresenta por fotografias de obras de arte de urbana 
denominadas de lambe-lambe, que estabelecem sentidos acerca da mulher e seu corpo em nossa contemporaneidade. Esse arquivo é acessível nas plataformas digitais do Instagram e do Facebook dos espaços consultados, estabelecendo ali sentidos múltiplos e polissêmicos, sendo constituído de tensões que envolvem a produção de outros sentidos sobre o corpo da mulher que não os sentidos já estabilizados por uma memória patriarcal. Chegar ao corpus de uma pesquisa é um processo de selecionar e recortar o arquivo e, de modo que seja composta a discursividade.

A variedade de tipologias de contas e perfis que trabalhavam com a temática do feminino e a luta por novos sentidos, assim como o nosso objetivo em analisar o movimento político que é imbricado ao espaço urbano e ao espaço digital, fez com que delimitássemos nossa análise em apenas três perfis que funcionam como um espaço de circulação e de 'coletânea' de intervenções artísticas de rua, com a temática do feminino. Para estabelecer esta escolha, foram criados alguns critérios acerca dos perfis, sendo estes: 1) serem perfis brasileiros; 2) escritos em língua portuguesa; 3) pertencentes a mulheres; 4) que versassem questões sobre o feminino e os sentidos sobre o corpo da mulher em nossa contemporaneidade; 5) que contivessem obras de arte de lambe-lambe; 6) que não houvesse proibições de acesso ao seu conteúdo.

Assim, para compor o nosso corpus, decidimos analisar os posts de dois perfis do Instagram (@projeto.encontrarte e @lela.brandao) que seguem os critérios acima. Resgatamos, também, a descrição desses na plataforma do Facebook, bem como algumas notícias/reportagens na web sobre esses perfis, de modo a compor algumas análises do corpo do texto dos nossos capítulos. É importante colocar que esses perfis contêm respectivamente: 1394 publicações o primeiro, 363 o segundo, 958 o terceiro e 2685 o quarto e que nem todas as publicações se adequam aos critérios. Algumas publicações repetem as mesmas obras e outras não são compostas por fotografias de obras de arte de lambe-lambe, e sim por fotos de obras literárias que algumas das mesmas autoras das obras publicaram. Deste modo, delimitamos o número de obras em nosso material, amparados pela definição da escolha da temática que comporta nosso objetivo de pesquisa, sendo esta, "corpo de mulher", sendo este critério não deslocados do movimento da teoria utilizada.

Diante de nossos objetos discursivos, passamos a compor nosso recorte discursivo, que nada mais é que um gesto de leitura do pesquisador. Para isto, segundo Bastos (2018), realiza-se a segmentação do corpus discursivo, lançando mão do dispositivo teórico-analítico da $\mathrm{AD}$, correlacionando-o com os objetivos da pesquisa e desvelando-se o funcionamento do discurso e como este produz sentidos. Assim, partimos das materialidades discursivas das 
obras compartilhadas nos perfis de Instagram já delimitados, buscando nelas as regularidades discursivas que se fazem presentes nesses discursos.

Observamos, dessa maneira, quais categorias de análise da AD podem ser instrumento de reflexão e (busca por) um olhar crítico sobre os processos de constituição, formulação e circulação de sentidos sobre/para o corpo da mulher em rede a partir dessas obras. Ou seja, iremos observar como os dispositivos teóricos e analíticos da $\mathrm{AD}$ operam na materialidade do nosso corpus. Tendo identificado isso, o analista do discurso inicia o trabalho de interpretação. Assim, a partir da materialidade das obras, estabelecemos gestos de leitura e interpretação de todo material selecionado para esta pesquisa, procurando desfazer o efeito de transparência da linguagem, desnaturalizando, então, sentidos que aparentemente são evidentes e que se inscrevem nas obras.

Desta maneira, a partir de um gesto de análise discursiva, buscamos vestígios acerca do modo de funcionamento da ideologia na regularização de dizeres, tendo em vista os conceitos aqui já mobilizados para uma melhor compreensão dos modos de funcionamento desses dizeres na atualidade, bem como os seus efeitos na regularização de uma memória do dizer sobre a mulher em nossa contemporaneidade. Como resumo de nossa atividade de pesquisa, descrevemos abaixo as etapas que se realizaram no decorrer dessa pesquisa:

- Levantamento bibliográfico de materiais que permitem a nossa reflexão acerca das questões levantadas no decorrer do texto. As consultas e os materiais bibliográficos foram obtidos em diferentes espaços; não nos atendo somente aos conceitos fundamentais da $\mathrm{AD}$, mas também a publicações acerca da temática do ciberespaço, da tecnologia, dos sentidos sobre feminino e de seu corpo em nossa contemporaneidade;

- Observar o acervo de obras desses perfis: A primeira etapa consiste em apreender os padrões de significado que forem visíveis como um todo e anotar as impressões;

- Seleção dos recortes e constituição do corpus: Formulamos, nesta etapa, questões que irão movimentar nossa investigação e que têm relação com o objeto de nossa pesquisa. Assim, lançamos mão de algumas perguntas como: o material, isto é, as obras manifestam a presença, a passagem, a permanência, os afetos, as angústias, os sofrimentos, o erotismo, as exclusões, as denúncias e as lutas do sujeito quanto ao seu corpo da mulher em sociedade? Ou seja, o artista nessas obras faz circular sentidos sobre o corpo feminino em suas obras? A partir disso, serão detectadas obras-chave a serem percebidas pelo pesquisador. Tal etapa irá 
zelar por pincelar as obras que expressam sentidos sobre o corpo feminino. Ademais, durante esse momento, está prevista a fase de delimitação dos recortes que serão analisados ao longo de toda a pesquisa, compostos pelas perguntas guiadas, em especial pelos objetivos específicos expostos neste trabalho;

- Identificação de sequências discursivas: Coletadas as sequências discursivas individuais na etapa anterior, o analista é levado a descrever padrões detalhados expostos nesses fragmentos. Aqui, procuramos os rastros da ideologia, do inconsciente, os silenciamentos, as formações discursivas e o resgate da memória acerca do corpo da mulher conforme operados pelo sujeito na circulação de sentidos dos processos discursivos verbal e não-verbal;

- Descrição do funcionamento discursivo: Padrões, nas formações discursivas, dos segmentos colhidos na segunda etapa, depois analisados e estruturados na terceira, vão evidenciar padrões na significação e no modo como o sujeito se constitui na linguagem (artística). A articulação desses resultados com os conceitos teóricos da $\mathrm{AD}$ e de teóricos de outras áreas da Psicanálise Lacaniana irão enriquecer a pesquisa e dar conta da materialidade subjetiva posta ali, podendo, enfim, responder à questão de pesquisa e levar nossas análises rumo ao objetivo geral. 


\section{O FEMININO E(M) DISCURSO: SENTIDOS SOBRE/DO CORPO EM MOVIMENTO}

Figura 10 - Obra da artista plástica brasileira Siss

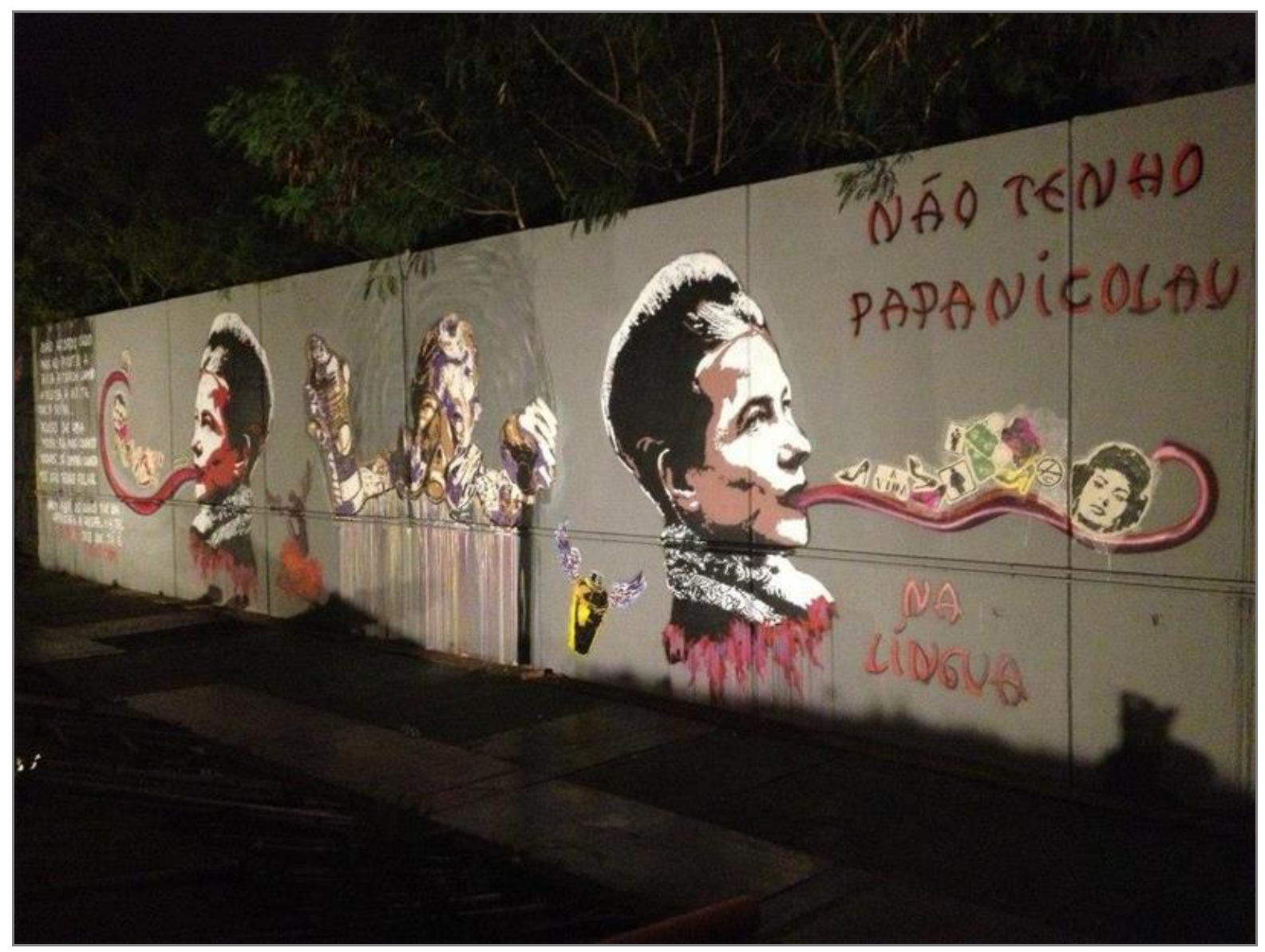

Fonte: https://naomekahlo.com/5-grafiteiras-que-voce-precisa-conhecer/

Triste, louca ou má será qualificada ela quem recusar seguir receita tal

(Francisco El Hombre, “Triste, Louca Ou Má”) 
Nas relações sociais, a articulação do simbólico com o político está na base da constituição das subjetividades e da própria existência humana. Os dizeres (e sentidos) sobre o corpo, e em especial o corpo da mulher, não estão dissociados dessa articulação.

Ao pensarmos nos efeitos da memória discursiva diante do sujeito mulher, historicamente determinado por padrões e papéis, vemos que a opressão feminina está inerente em nossa sociedade até os dias de hoje, e permanecerá a menos que haja mudanças significativas em nossa sociedade. Sendo assim, o corpo da mulher, assim como o corpo social, não está desnudo da ideologia que o cerceia, que o convoca e que, muitas vezes, o aprisiona em determinados padrões, sejam eles estéticas e /ou de conduta em sociedade. Conforme Orlandi (2012, p. 10)

\footnotetext{
Não há corpo que não esteja investido de sentidos e que não seja o corpo de um sujeito que se constitui por processos de subjetivação nos quais as instituições e suas práticas são fundamentais, assim como o modo pelo qual, ideologicamente, somos interpelados em sujeitos. Dessa forma que pensamos que o corpo do sujeito é um corpo ligado ao corpo social e isto também não lhe é transparente.
}

O corpo inscrito em superfícies de muros, postes, prédios e viadutos produz modos de dizer do feminino inscritos em condições de produção específicas. O espaço digital, por sua vez, proporciona um modo de funcionamento das práticas políticas contemporâneas que não se dá a despeito dos sujeitos envolvidos no processo discursivo e de suas condições históricas de produção, articulação, determinação e circulação.

Conforme já dito, segundo Orlandi (2002), o processo discursivo se realiza em três níveis: constituição, formulação e circulação. Para a autora, a constituição do dizer se estabelece a partir de uma memória do dizer no e pelo qual se marcam os sentidos relativamente estabilizados na formação social, advindos de discursos outros já-ditos; a formulação se efetiva, tendo em vista as condições de produção desses dizeres nas quais se ligam às circunstâncias da enunciação. É no nível da circulação, por sua vez, que a memória se atualiza, fazendo intervir os sujeitos e os sentidos num jogo ininterrupto entre atualidade e memória, a partir de condições de produção do discurso específicas de cada tempo, cada formação social.

Acerca da relevância desses níveis no processo discursivo, Orlandi (2002, p. 33) afirma que:

a constituição determina a formulação, pois só podemos dizer (formular) se nos colocamos na perspectiva do dizível (interdiscurso, memória). Todo dizer, na realidade, se encontra na confluência dos dois eixos: o da memória (constituição) e o da atualidade (formulação). É desse jogo que tiram seus sentidos. 
Dentre esses três momentos envolvidos no processo de produção do discurso e desenvolvidos pela autora (Orlandi, 2002), é o da circulação que nos interessa mais precisamente, uma vez que, segundo Dias (2018, p. 33): "O que sustenta a formulação dos dizeres no digital é a sua circulação", sendo esse "o ângulo de entrada no processo de produção dos sentidos" (Dias, 2018, p. 33). Como nesta pesquisa analisamos essas discursividades a partir do digital, buscamos compreender a formulação desses dizeres, pela atualização da memória de um dizer, de modo a verificarmos o processo de produção de sentidos para o corpo feminino, que circulam na rede, tomando em atenção as retomadas, os deslizamentos e os deslocamentos de sentidos que se materializam nos lambe-lambe, na relação com os sentidos historicamente naturalizados sobre a mulher e o seu corpo.

Vivemos em uma sociedade que compactuou e ainda o faz com diversos discursos de violência contra o corpo feminino. Vemos que, hoje, as novas mídias têm contribuído para a emergência de discursos acerca da mulher com base em estereótipos pré-estabelecidos. A mulher é discursivizada e seu corpo é significado nos discursos. Para tanto, em um primeiro momento, analisamos obras de oito lambe-lambes que nos dizem acerca de uma idealização do corpo e da beleza feminina que se faz presente na mídia, quer digital quer não, considerando os sentidos que se materializam nestas obras. A seguir, lançamos, mais uma vez, uma escuta a cinco lambe-lambes que fazem emergir um chamado à subjetividade do ser mulher, tendo em vista as questões que nele envolvem, tais como o desejo de ser e de (se) amar. A partir desses gestos de interpretação, tomamos em atenção quatro lambe-lambe cujos sentidos se entrelaçam num corpo que circula entre o público e o privado.

\subsection{O corpo idealizado na/da contemporaneidade}

Segundo Sanches e Sousa (2018), a busca por um padrão de corpo não é algo novo, mas que, mesmo podendo sofrer mudanças de valor ao longo do tempo, cada cultura tem sua configuração específica de corpo ideal. Segundo esses autores, o corpo é produto de uma subjetivação pela qual se marca uma alteridade constitutiva que compreende um conjunto de imagens e discursos que remetem o analista a determinado contexto sócio, histórico e ideológico.

Esses autores ainda colocam que o corpo da mulher contemporânea é discurzivizado a partir de um ideal de magreza, que os teóricos denominam de corpo-projeto, sendo este naturalizado pela mídia e gerado, muitas vezes, artificialmente a pela aquisição de tratamentos, procedimentos e produtos alimentícios que são comercializados e divulgados na 
grande mídia. Tal padrão é formulado discursivamente a partir da ilusão do sujeito de poder alcançar este modelo por meio das técnicas, práticas e hábitos vendidos e propagandeados, como veremos adiante.

Os autores levam-nos ainda a refletir sobre a maneira como esse sujeito discursivo se posiciona frente à existência de uma ditadura do corpo ideal. Esta, hoje, é extremamente incentivada pelas revistas e redes sociais e que, por meio da resistência e do empoderamento faz ranger discursos ditatoriais sobre como deve ser ou não o corpo de uma mulher. Sousa (2009 apud Sanches \& Sousa, 2018, p. 4) nos diz que "[...] um conjunto de discursos faz os corpos comportarem-se de uma determinada forma ou de outra, ou seja, modelos 'discursivizados' desencadeiam forma-sujeito de um corpo perfeito (para determinados ambientes da esfera social)".

É por meio desse jogo de discursos idealizados de forma-sujeitos que podemos visualizar o funcionamento da ideologia sobre corpo feminino, legitimando o que deve ser compreendido como o formato ideal de corpo e o que não o é. Fortalecido pelas redes e pelos meios midiáticos, o corpo da mulher aparece como produto a ser vendido e comercializado, já que ele entra como objeto de propaganda de muitos produtos (im)postos, por exemplo, nos discursos das novas dietas e que são altamente consumidos. Ou seja, o corpo é colocado como objeto final a ser atingido com o uso de certos produtos ou a utilização de certos procedimentos, gerando lucro para a indústria da beleza e da ditadura do corpo magro. Ainda de acordo com Sanches e Sousa (2018), o sujeito consumidor dessas revistas se apoia no discurso midiático das dietas para tentar emagrecer, sendo interpelado pela ideologia da magreza e atreladas às formações discursivas das dietas e do corpo-projeto.

Assim, a sociedade lucra com a insegurança estabelecida a partir de uma ideologia dominante de prática capitalista. Sendo esta atravessada e constituída pelo discurso e midiático de mercado (Sanches, 2018). O discurso sobre um padrão de beleza nos traz à memória uma beleza idealizada desde a Grécia Antiga, por meio dos contos mitológicos, tal como Afrodite - Vênus, para os romanos - a deusa da beleza, jovialidade e fertilidade. Segundo Daróz (2020), estes atributos idealizados em deusas extrapolaram as narrativas mitológicas para se materializarem nas práticas das mulheres atenienses, produzindo uma relação hierárquica de subserviência da mulher perante o homem, que, em certa medida, ressoa na atualidade.

Uma das especificidades do digital é proporcionar aos sujeitos que neles se inscrevem um efeito de anonimato, cujas vozes se dispersam. Constitutivas de gestos de autoria, essas vozes inscrevem-se a partir de um "nós" coletivo que desloca a prática política do individual 
para o coletivo. No entanto, o que observamos no lambe-lambe (figura 11) é uma particularização - uma convocação à subjetividade, entendida por "Você" - do sujeito interpelado, e de certa forma identificado, a uma formulação discursiva machista que aprisiona e cerceia o sujeito mulher a fim de que responda às exigências para uma padronização de mulher ainda vigente em nossa sociedade.

Figura 11 - Postagem do perfil @lela.brandao no Instagram em 23/05/2017

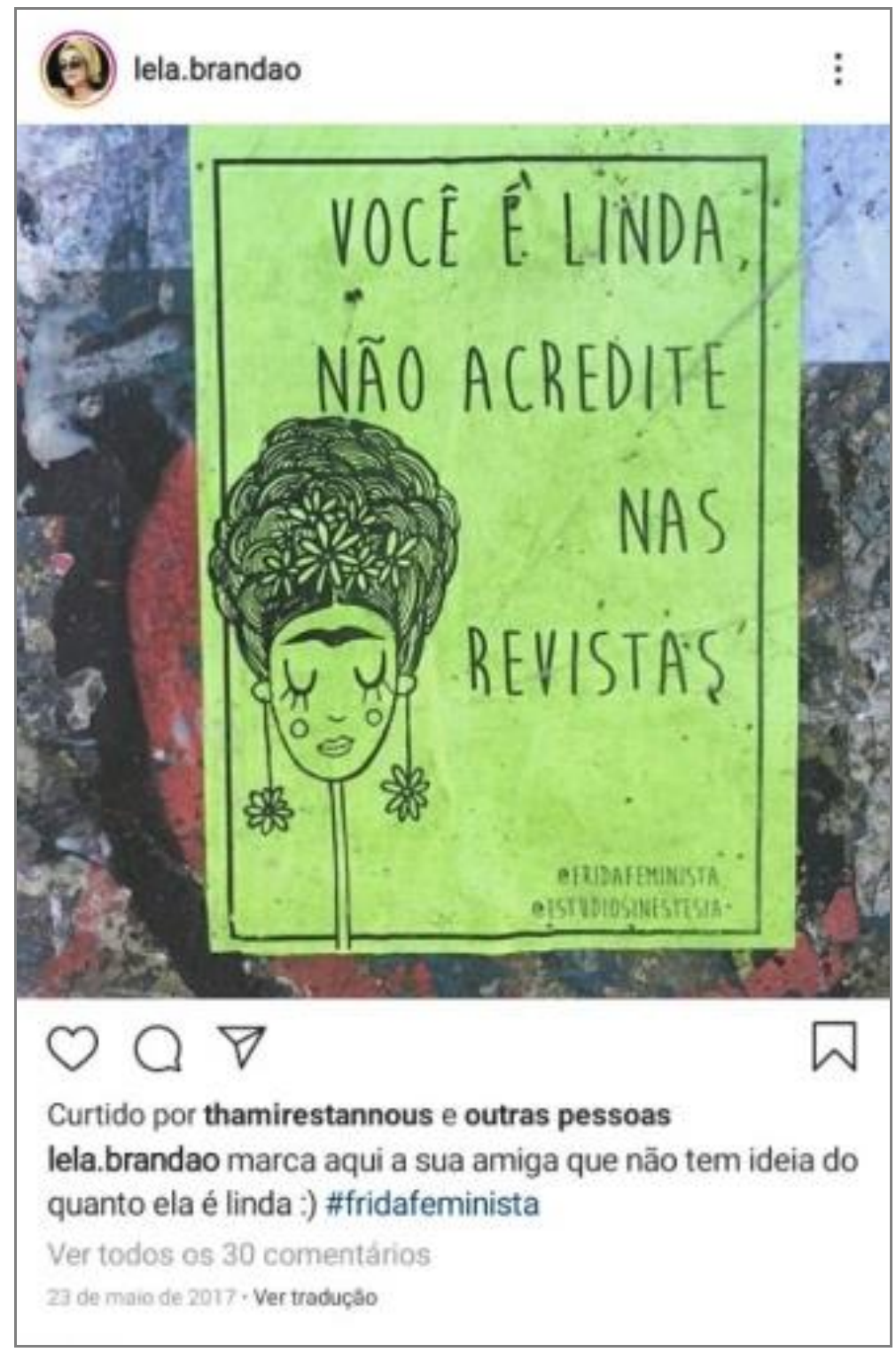

Também, vemos em tal formulação o modo de funcionamento dos sentidos que interpelam o sujeito por meio de revistas que, abrangendo um público diverso em idade e classe social, dentre outras estratificações, promove uma naturalização dos efeitos de sentidos

\footnotetext{
${ }^{9}$ Recuperado de https://www.instagram.com/p/BUc4nxtgOge/
} 
acerca da mulher e seu corpo. Como já levantamos, os sujeitos hoje são afetados nos espaços midiáticos, sendo estes locais de intensa constituição dos sentidos e dos sujeitos. Segundo Payer (2005), a mídia hoje exerce grande influência na formulação de sentidos sobre um ideal de corpo, afetando não só a formulação e a constituição dos sentidos, mas também a estrutura econômica e comercial de nossa sociedade.

Como bem aponta a obra de lambe-lambe, pelas revistas, ainda hoje, é possível encontrar modelos com corpos irreais, bem como, produtos cujo poder para aquisição também o são, estando muitas vezes, ambos na ordem de um impossível de se atingir. Assim, podemos perceber a atuação do ambiente midiático enquanto um espaço de referência e credibilidade à comportamentos e estereótipos de beleza, constituindo assim nossos sujeitos de nossa contemporaneidade. A esse estereótipo de beleza, na grande maioria das vezes, só incluem mulheres brancas, heterossexuais, cisgêneras e magras. Ficando assim, o restante dessas mulheres sem representatividade em revistas de beleza.

Esse processo de significação do corpo materializado nos discursos das revistas indicam para um possível a ser atingido, a partir de sentidos colocados em circulação ali. Assim, o corpo, em sua materialidade discursiva e empírica, é afetado pelas exigências veiculadas pelas revistas e dispostas e impostas no mercado, sendo tal fato levantado pelas obras de lambe lambe como prejudicais a forma como a mulher pode se compreender.

De acordo com Mariani (1996), é nas práticas sociais de fixação da memória que se encontram entrelaçados aquilo que deve ser lembrado, ou o que deve cair no esquecimento, de acordo com interesses inerentes às formações ideológicas vigentes. Observamos, na figura 12, que os sujeitos produtores dos dizeres que se materializam no lambe-lambe se contraidentificam com a ordem vigente que naturaliza um ideal de feminino, possibilitando um esgarçamento desses sentidos historicamente regularizados sobre um modo de ser mulher e que se marca no corpo. 
Figura 12 - Postagem do perfil @lela.brandao no Instagram em 13/03/2017

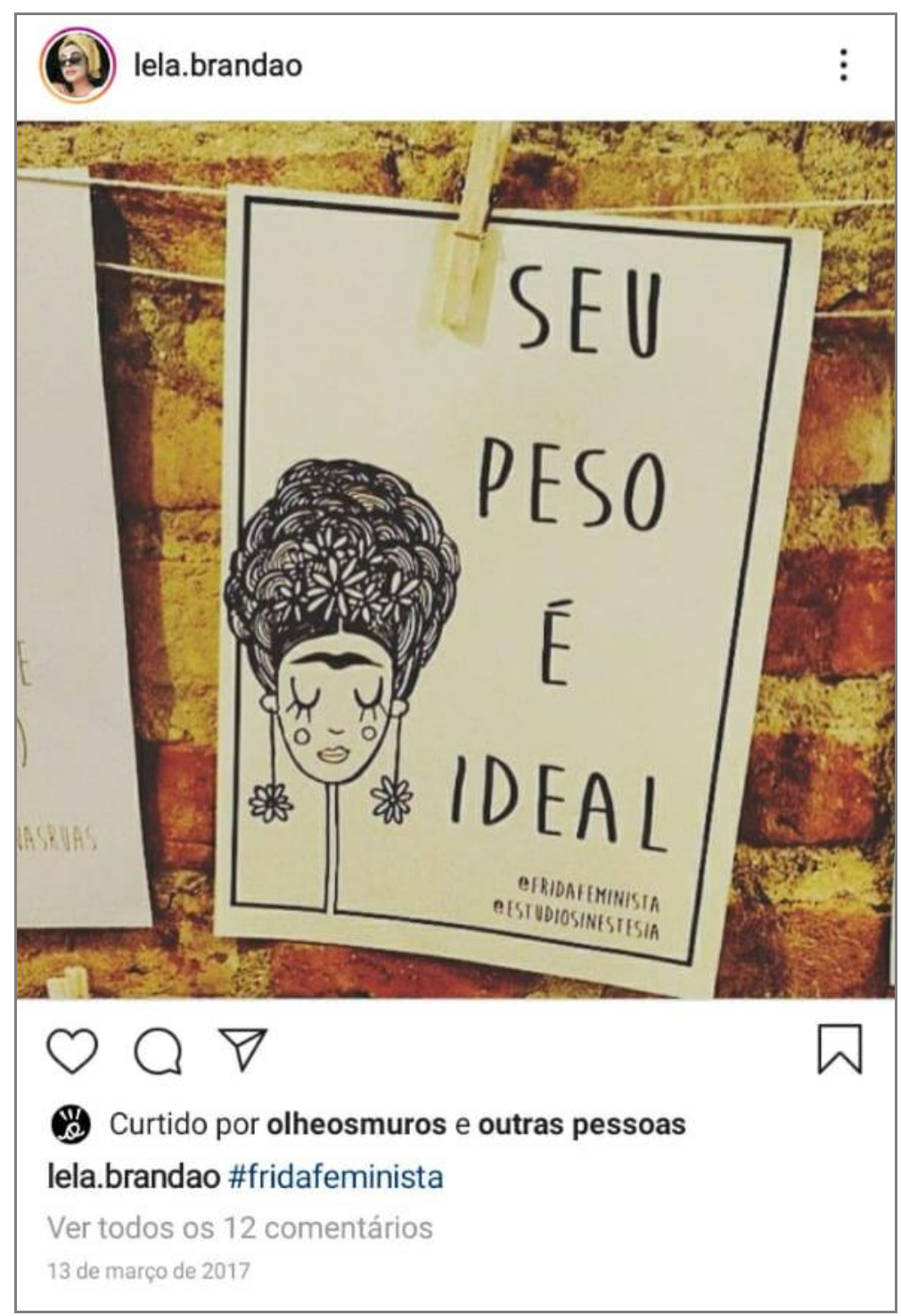

Podemos ver, então, a partir da obra acima, que o lambe rompe com os sentidos estabilizados de inadequação de corpo, desnaturalizando esses sentidos postos em circulação em nossa contemporaneidade. Segundo Mariani (2009), a naturalização dos dizeres /sentidos são efeitos de práticas dos sujeitos e entre sujeitos, concebidas como culturais, concernentes a uma determinada formação histórica, isto é, da relação que o sujeito estabelece com o exterior, revelando uma alteridade constitutiva na sua relação entre o "eu" que enuncia, particular e individual, e a exterioridade que o assujeita, o habita e o constitui. Nessa relação, a ideologia, a partir de seus aparelhos ideológicos, atua como fator preponderante na constituição dos sentidos.

\footnotetext{
${ }^{10}$ Recuperado de https://www.instagram.com/p/BRmS04oA4zs/
} 
A mídia faz circular, em seus diversos níveis, sentidos sobre um corpo a ser desejado, sobretudo pelo olhar masculino; um corpo en-forma. Sentidos que vão do particular ao coletivo, produzindo efeitos nas práticas sociais, em especial no que tange à relação da mulher com o seu corpo - consigo mesma, portanto - assim como com o outro.

Figura 13 - Postagem do perfil @lela.brandao no Instagram em 16/05/2017

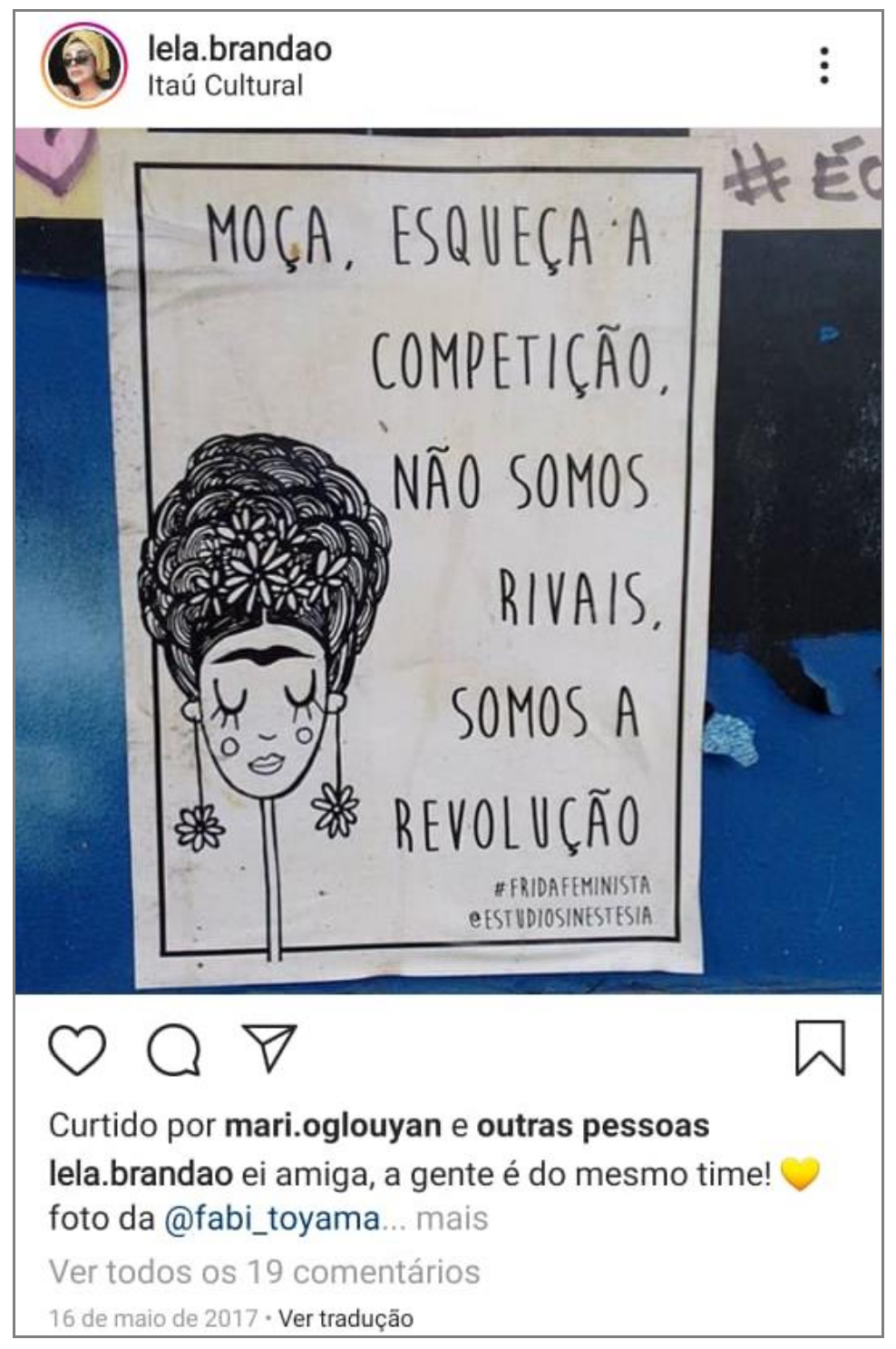

O lambe-lambe aqui exposto na figura 13 nos diz da existência de uma competição entre mulheres, uma relação de oposição, produzindo-se então na obra de lambe lambe, o efeito de que existe uma comparação de quem é a melhor em nossa sociedade hoje. Sabemos que, a adequação a um padrão de corpo é ainda hoje fruto de comparação entre as mulheres, havendo formações discursivas que apontam que a mulher magra é melhor, estando assim a

\footnotetext{
${ }^{11}$ Recuperado de https://www.instagram.com/p/BULDbJwAcb-/?igshid=pl3dc6ppxjxy
} 
frente de uma competição. É importante também se atentar nas figuras utilizadas pela autora Lela Brandão em suas obras é sempre acompanhada de um desenho da pintora Frida Kahlo, mulher deficiente, sendo também um direcionamento da autora para outros corpos (como o deficiente) que muitas vezes não está inserido como belo no discurso em nossa sociedade.

Tal fato também pode ser observado na no lambe-lambe (Figura 13), o verbo flexionado na $1^{\text {a }}$ pessoa do plural, "Somos", faz emergir sentidos de universalização, assegurando a ideia de que as mulheres, enquanto categoria sujeita aos desmandos e a violências de nossa sociedade, devem se unir em prol de uma "coletividade". Sob esse viés, em contraposição ao sentido de apagamento do sujeito, os dizeres ali inscritos fazem emergir, ainda, a complexidade do feminino, produzindo o efeito de uma particularização do universo feminino, com suas demandas e seus desejos e o apagamento das diferenças, próprio das relações sociais, que produz a anulação dos sujeitos sob forma de violência em seus diferentes níveis.

As próximas figuras tratam também das mesmas redes de sentido acerca da imposição de um padrão de corpo a mulher. 
Figura 14 - Postagem do perfil @ projeto.encontrarte no Instagram em 11/09/2018

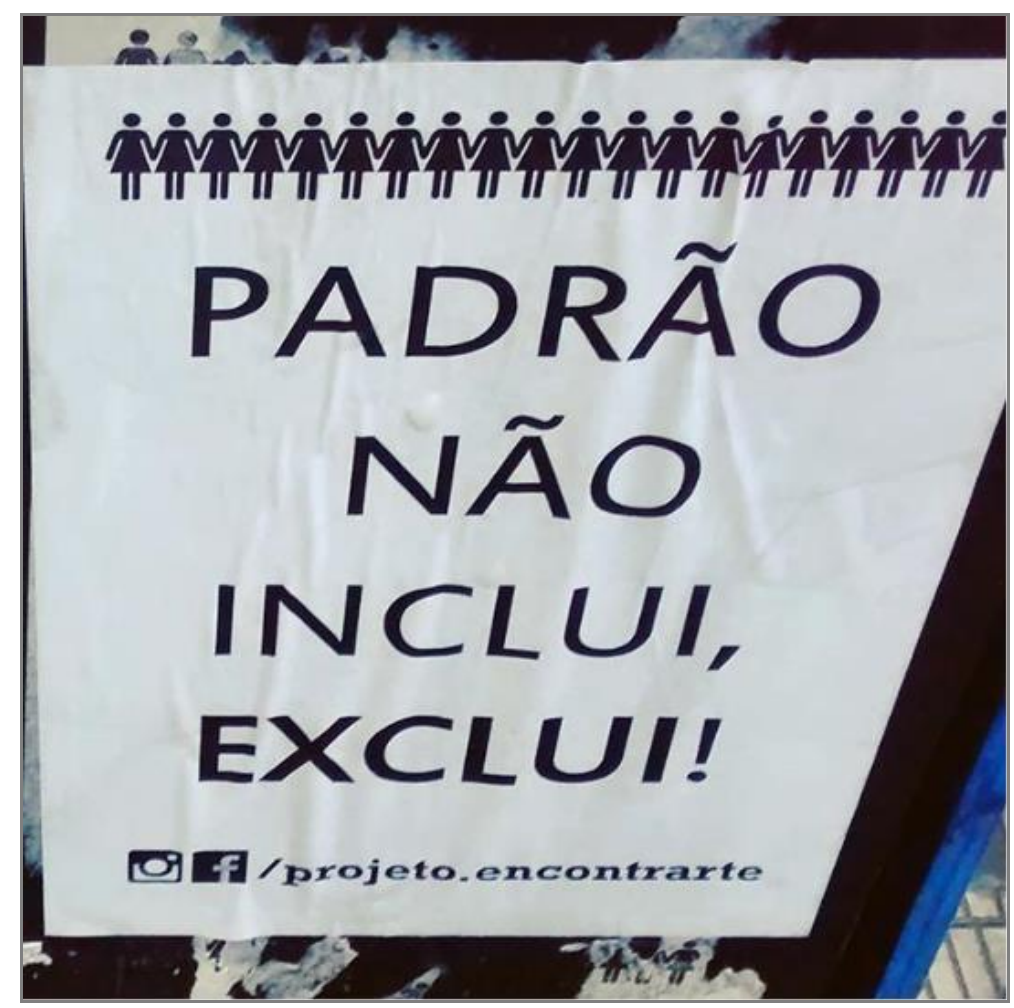

Figura 15 - Postagem do perfil @ projeto.encontrarte no Instagram em 10/09/2018 13

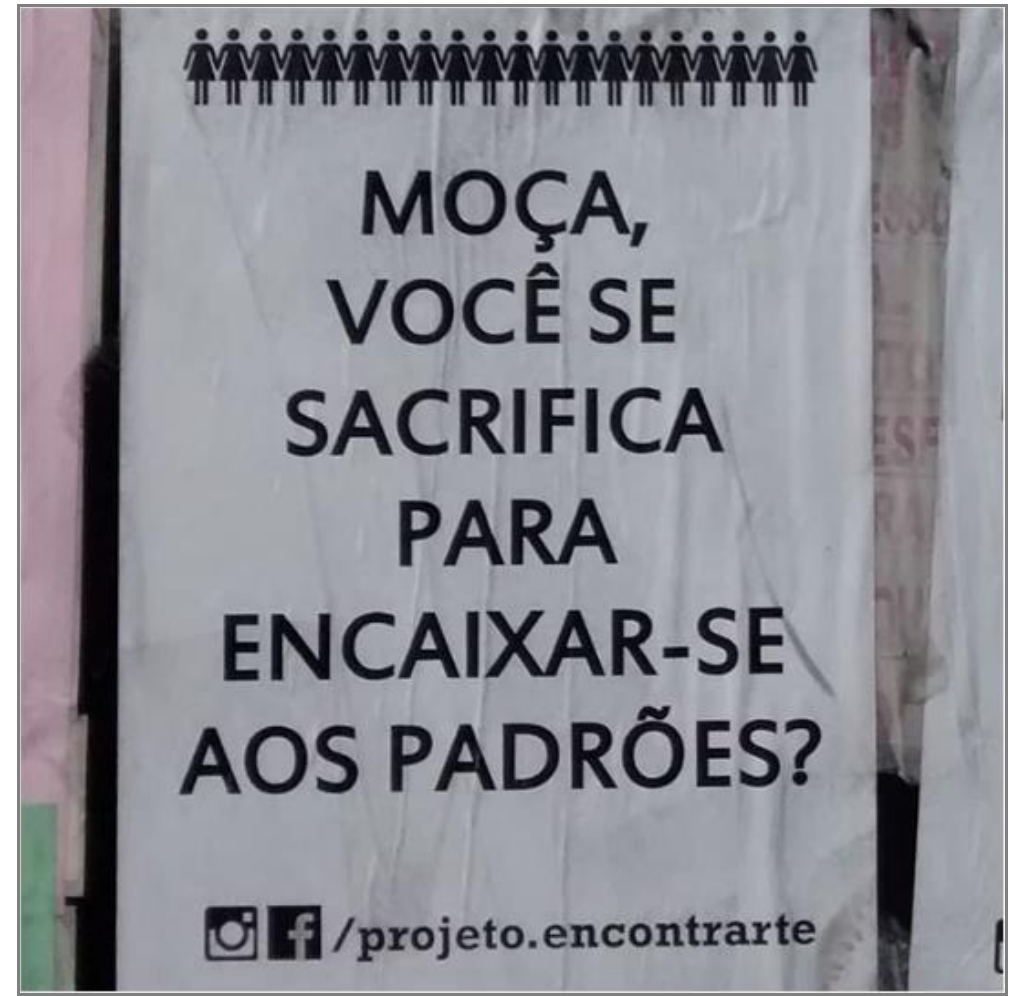

\footnotetext{
${ }^{12}$ Recuperado de https://www.instagram.com/p/Bnl8Xsyh2eE/

${ }^{13}$ Recuperado de https://www.instagram.com/p/Bnj3ij4hi99/
} 
Ao longo dos tempos, a padronização do corpo era, e ainda é, significada como fator de inclusão dos sujeitos, de forma a direcioná-los a determinadas práticas sociais. Por meio da confluência entre o imagético e o linguístico, observamos nas figuras uma desnaturalização dos sentidos relativamente estáveis na esfera social acerca do padrão desejável do corpo feminino a ser seguido pelos sujeitos. Percebemos que essas sequências instauram importantes significantes a serem, aqui, analisados como as temáticas quanto a padronizações da beleza e a não liberdade do corpo. Ao tomarmos esses recortes, é possível conferir uma tentativa de ruptura e de resistência ao funcionamento discursivo de uma ideologia dominante, que estabiliza sentidos sobre o corpo feminino na atualidade. A autora do @projeto.encontrarte faz isso por meio da polissemia que a língua confere, saltando-nos alguns termos como luta, revolução, corpo; sacrifício, encaixar-se, inclusão e exclusão, que instauram gestos outros sobre o corpo da mulher, como o de liberdade, por exemplo.

Como alguns dos efeitos de naturalização dos dizeres aparentemente evidentes quanto a um ideal de beleza feminina, de corpo ideal, muitas meninas e mulheres de diferentes faixas etárias e nível de escolarização e classe social têm exposto o seu corpo a atender a um determinado padrão de (e para a) mulher. Acerca disso, as figuras 14 e 15 convocam o sujeito contemporâneo, a mulher em especial, a repensar tais práticas. Encaixar-se nos traz à memória um ato de colocar-se em caixas, mas não de qualquer forma ou em qualquer caixa. Encaixar-se aos padrões de beleza é moldar-se a determinadas características estéticas; enformar-se.

Por uma rede parafrástica de sentidos acerca dos termos moça/sacrifica/encaixar-se e padrões, observamos na imagem um apelo, uma convocação, às mulheres, em especial, para possibilidades outras de ser sujeito, de ser mulher na contemporaneidade. Sendo assim, um ato de resistência à ordem vigente, o lambe-lambe opera no sentido de in-formar os sujeitos contemporâneos a respeito dessa liberdade, ainda que relativa, de ser você mesma. Nesse mesmo movimento, no lambe da figura 14, estabelece-se uma rede de sentido que rompe com os sentidos acerca de um padrão fixo para o corpo feminino. Ao fazer ressoar que "Padrão não inclui, exclui", percebemos um gesto de resistência a sentidos machistas que se apropriam de uma discursividade de corpo projeto e ideal, próprio a circular pelo desejo mercadológico e para o imaginário masculino. Por esse viés, segundo Scherer (2010), a escrita trata-se de um gesto de resistência em que o sujeito vai:

[...] des-criar o que existe [...] ir em busca de nossa história [...] capacidade de jogar com a letra e, ao mesmo tempo, de viver na intimidade de um ser estranho, para não fazê-lo conhecido, e sim para estar ao lado dele sem medo de ficar entre o dizível e o indizível [...] Restos que sobram da vida e da história 
que não efetuamos apenas em um ritual de protesto, mas nessa tarefa silenciosa e paciente que se torna, mais tarde, uma angústia da/na alma (SCHERER, 2010, p. 118).

Percebemos, então, ao entrar em contato com o corpo de letras postas nas obras de lambe-lambe, a possibilidade de se des-criar os sentidos que já existem sobre a mulher e o seu corpo, sentidos identificados a uma memória discursiva machista e mercadológica. De acordo com Garcia (2014, p. 299), na interpelação ideológica do sujeito mulher, a posição-sujeito dessa aparece atravessada por um "discurso patriarcal, machista, que coloca a mulher em um lugar de submissão, de sexo frágil, de objeto".

Assim, os sentidos postos nestas obras analisadas não se identificam com esse discurso dominante, estabelecendo, então, um gesto de resistência que busca: “fundar um dizer no qual se reconheça como sujeito, busca irromper com seus outros sentidos para ecoar na sua história" (Garcia, 2014, p. 299).

Sendo assim, romper com esses sentidos é identificar-se com saberes outros, convocando os sujeitos a deslocarem suas posições no discurso, fazendo circular sentidos outros, construindo discursivamente um outro lugar para essa mulher que fala, que produz, que cola na rua e que circula na rede. A partir desses recortes, refletimos acerca de todas as conquistas e das lutas pela equidade de direitos em relação ao homem e da desobjetificação do corpo feminino que ainda se promovem por meio de discursos regularizados, estabelecendo um certo ideal de corpo da mulher. É importante, pois, problematizar que por essas obras estarem depositadas em locais (na rua e na rede) de circulação pública, em que não se regula um dizer, mas regula o encontro com o furo da ideologia dominante com as obras, isso permite entrar exatamente na brecha para realizar um contra discurso aos sentidos dominantes sobre a mulher, sendo este um mote de reflexão a partir do lambe-lambe que se faz presente na figura 16. 
Figura 16 - Postagem do perfil @ projeto.encontrarte no Instagram em 27/04/2018 14

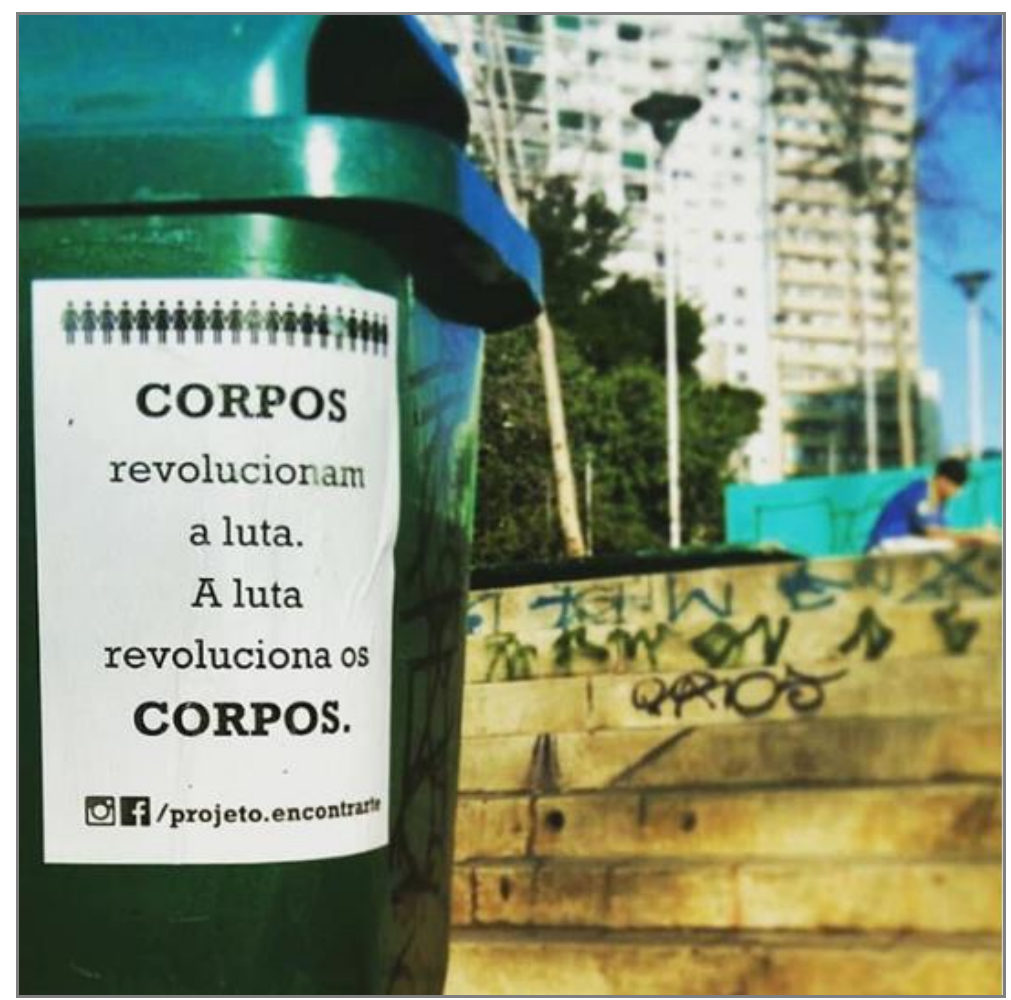

Por meio de um ritual aparentemente inequívoco, a ideologia direciona os sujeitos a ocuparem os seus lugares pré-determinados na esfera social. No entanto, como afirma Pêcheux (1975), não há ritual sem falhas, visto que a resistência é constitutiva do sujeito. Em atos de resistência ao discurso machista vigente, as lutas por novos sentidos sobre a mulher proporcionaram questionamentos e reivindicações condizentes com as especificidades de cada momento histórico, apontando não apenas às suas demandas, como também para novas formas de ser sujeito, trazendo com ele marcas da historicidade. Por meio de diferentes dizeres e posicionamentos, os movimentos históricos em prol das mulheres expuseram no meio social as fissuras, os equívocos do discurso hegemônico machista, deixando-nos um legado de resistência e luta em contraposição a esses dizeres, em face à emergência de instauração de novas práticas atualmente.

No sentido de ressignificação desses discursos machistas, podemos refletir que mesmo com toda a historicidade do movimento feminista e a evolução de suas conquistas até os dias atuais - percurso que, de certo modo, trilhamos nos capítulos anteriores - existem, ainda, sentidos fixos acerca de um imaginário de feminino e de beleza que essas obras vêm questionar. Pêcheux (1997, p. 85), em seu texto "Análise automática do discurso", diz que "a

\footnotetext{
${ }^{14}$ Recuperado de https://www.instagram.com/p/BiE1_NfBaip/
} 
percepção é sempre atravessada por um ‘já ouvido’ e o ‘já dito’, através das quais se constitui a substância das formações imaginárias enunciadas".

Desse modo, ao analisarmos o "padrão não inclui, exclui” (figura 14), tais artistas retomam a memória discursiva de que há um certo modelo em vigor (heterossexual. cisgênero, branco e magro), um sentido já pré-estabilizado discursivamente sobre o que é ser uma mulher, concepção atribuída e responsável por instaurar um lugar de discurso em que o que é ser mulher já é dado e caracterizado socialmente. Já o próximo recorte vai além, é responsável por retomar a memória de um sacrifício para atingir o corpo perfeito. Com isso, vemos um questionamento sobre o esforço que se solicita à mulher para entrar em um padrão, regido por um modelo patriarcal que vem para agradar a uma sociedade e ao capitalismo vigente com a indústria das dietas. Todavia, em relação ao terceiro recorte, vemos a maneira como o discurso feminista instaurou um discurso outro capaz de não só modificar o modo como a mulher é falada, mas também de como ela passa a lidar com o próprio corpo.

Figura 17 - Postagem do perfil @lela.brandao no Instagram em 07/02/2017

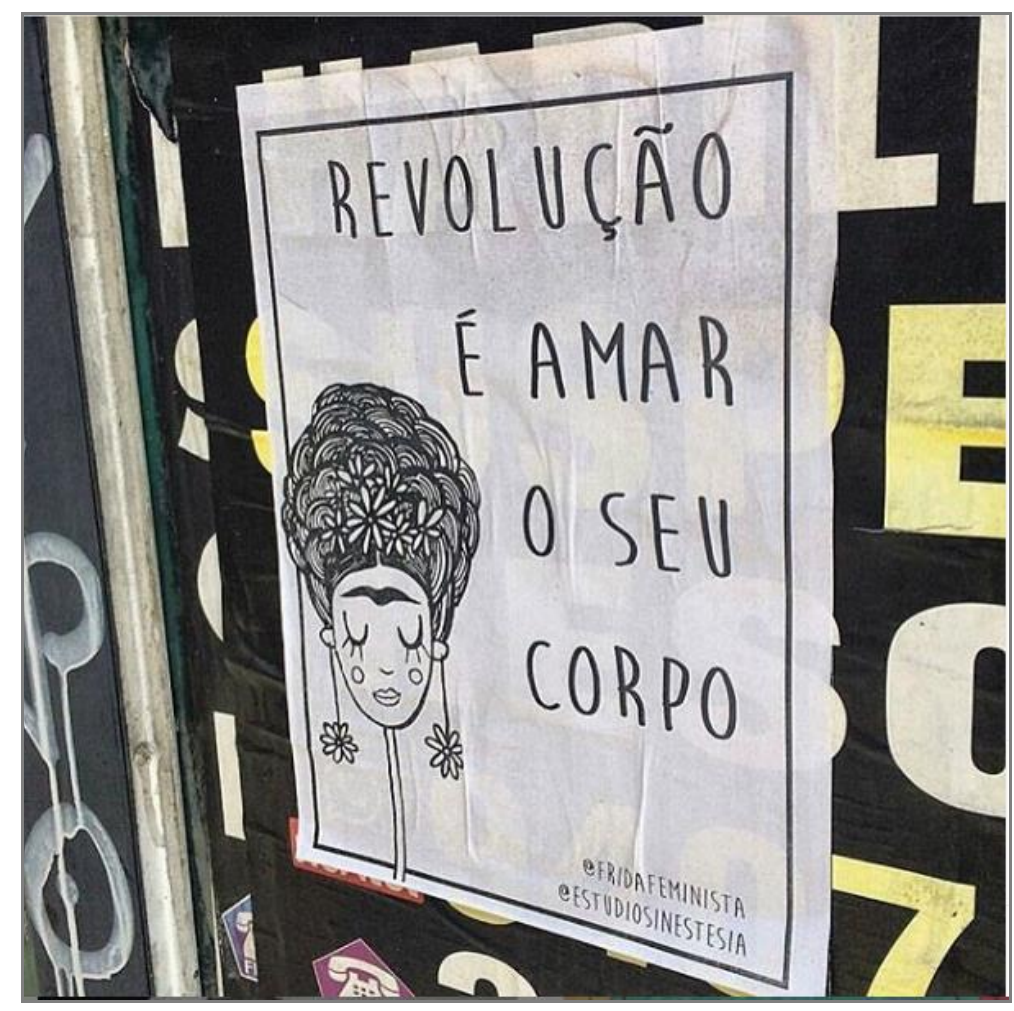

${ }^{15}$ Recuperado de https://www.instagram.com/p/BQOpvmbgppM/ 
Figura 18 - Postagem do perfil @ lela.brandao no Instagram em 03/05/2017

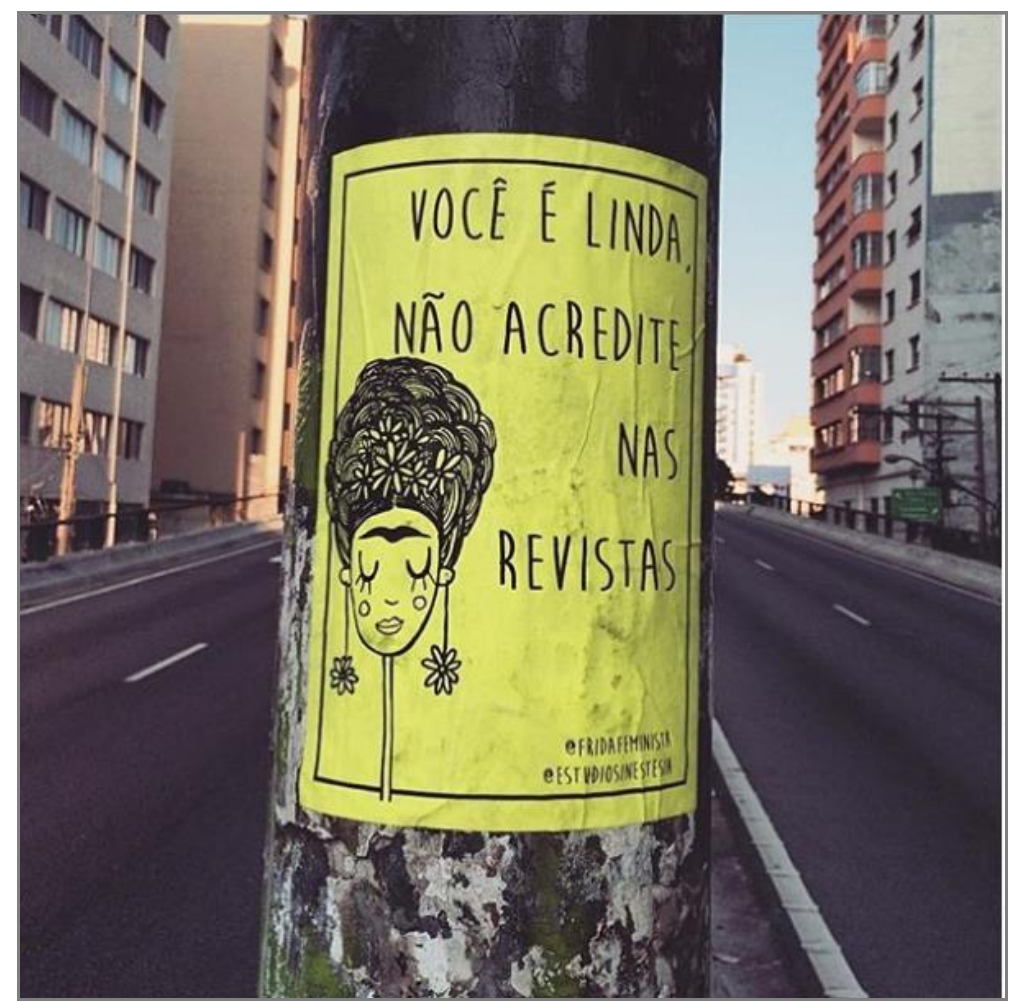

Os três recortes acima do perfil @lela.brandao, antiga página do @fridafeminista,nos levam a refletir sobre a existência de uma ditadura de corpo ideal que acomete a mulher contemporânea. Esses recortes manifestam sentidos de um padrão a ser incentivado em nossa sociedade, materializando-se em um conjunto de discursos que indicam como um corpo deve ou não se apresentar. Nesse jogo de discursos totalizantes é possível perceber o funcionamento da ideologia sob o corpo feminino. Ideologia essa que a reconhece apenas quando dentro de um ideal. Fortalecido por revistas, como apontado na obra, nossos corpos aparecem como um produto a ser adquirido, um objeto final que só pode ser atingido com o que ali é anunciado. Isso tudo, em troca de um alto capital, que não inclui a maioria das mulheres de nosso país.

Dessa forma, a subversão, realmente, é ir contra a corrente desse discurso que, muitas vezes, se coloca como ideal para muitos de nós. Podemos, assim, perceber que essas obras, usadas como resistência a tais padrões, exercem efeitos de tensão na sociedade em rede e estabelecem uma prática social que desloca/(ir)rompe com dizeres já pré-estabelecidos socialmente. É importante, pois, problematizar que por essas obras estarem depositadas em um local (na rua e na rede) em que não se regula um dizer, mas regula o encontro com o furo

\footnotetext{
${ }^{16}$ Recuperado de https://www.instagram.com/p/BTpXcM2AX6E/
} 
da ideologia dominante com as obras, essa situação permite entrar exatamente na brecha para realizar um contra discurso aos sentidos machistas dominantes.

Vivemos em uma sociedade capitalista cujas bases estão firmadas na relação de produção/dominação com vistas à sustentação do poder. Nessa relação, o lucro é um de seus pilares, produzindo diversas formas de dominação. O Brasil é frequentemente significado como o país de belezas naturais, que envolvem tanto a exuberância de nossa fauna e flora quanto à pluralidade de cores, gostos e formas dos brasileiros, e em especial da mulher, em herança da historicidade da formação do nosso povo. Diante desse apelo ao dito belo, segundo determinados padrões, a indústria cosmética, as propagandas, dentre outros, colocam à disposição inúmeros produtos que se atualizam em um curto espaço de tempo, prometendo jovialidade e realce da beleza. Sendo importante colocar que os sentidos de beleza que esses padrões impõe são a de um sujeito-mulher de poder aquisitivo alto, branca, cisgênero e magro. As obras de lambe-lambe, então, produzem efeitos de deslocamentos dos sentidos sobre a mulher, naturalizados em nossa sociedade, fazendo emergir à subjetividade constitutiva do sujeito.

\subsection{Um chamado à subjetividade}

Segundo Serrani (1998), a subjetividade estabelece discursivamente um meio pelo qual o sujeito, na e pela língua(gem), se constitui como sujeito do discurso. Esse processo se realiza a partir do movimento contínuo de inscrição de sentidos que se realiza em "traços significantes, interdiscursivos, inconscientes, que se realizam fundamentalmente por metáforas e metonímia" (Serrani, 1998, p.46).

Uma vez que buscamos nesse trabalho compreender o processo de produção de sentidos para o corpo feminino inscrito pela arte do lambe-lambe que circula em rede, consideramos que:

\footnotetext{
Não há corpo que não esteja investido de sentidos e que não seja o corpo de um sujeito que se constitui por processos de subjetivação nos quais as instituições e suas práticas são fundamentais, assim como o modo pelo qual, ideologicamente, somos interpelados em sujeitos. Dessa forma que pensamos que o corpo do sujeito é um corpo ligado ao corpo social e isto também não lhe é transparente. (Orlandi, 2012, p. 10).
}

Com isso, tomamos esse corpo de mulher enquanto um corpo constituído por processos de subjetivação, inscrito em superfícies de muros, postes, prédios e viadutos, assim como, em telas de celulares e computadores. Um corpo que se coloca a contestar os sentidos 
machistas socialmente sedimentados, se constituindo como um corpo que estampa e decora a cidade e as telas, ocupando um espaço público.

Orlandi (2002, p. 65) afirma que a subjetividade: "pode interessar, discursivamente, pelo fato de que ela permite compreender como a língua acontece no homem. [...] o acontecimento significante que é o discurso tem a noção de subjetividade como um lugar teórico fundamental". Em nossa historicidade, alguns sentidos, já legitimados, aparecem como dominantes em relação a outros, concebendo-se imaginariamente como verdadeiros e únicos. O sujeito do discurso é então capturado por esta rede de sentidos, filiando-se a uma memória discursiva e à formação discursivo. Assim, ao falar, retoma sentidos já todos na formação discursiva na qual se identifica. Assim, na constituição da subjetividade:

Ocorre um duplo processo engendrado pela inscrição do significante estruturando o inconsciente e constituindo o sujeito: uma identificação simbólica do sujeito à formação discursiva na qual ele se constitui e um assujeitamento ideológico aos sentidos que essa mesma formação discursiva, enquanto matriz de sentidos, produz (Mariani, 2006, p. 28).

Ou seja, o indivíduo, ao adentrar na linguagem, se constitui subjetivamente como sujeito do discurso. Tal processo somente ocorre tanto pela identificação a determinadas formações discursivas (FD), quanto pela identificação de uma ideologia a qual "'recruta' sujeitos" (Althusser, 1970, p. 99). Assim, a subjetividade em AD resulta, sim, do acontecimento da linguagem no sujeito, como salientado por Mariani (2006), sendo este acontecimento um "ponto de encontro de uma atualidade e uma memória" (Pêcheux, 2008 [1983], p. 17). Ou seja, "se é sujeito pelo assujeitamento à língua, na história” (Orlandi, 2002, p. 66).

Dessa forma, os sentidos são relativamente estabilizados, estando esses presentes em nossa memória discursiva que circula na e sobre a língua. Esses sentidos são inerentes a saberes interdiscursivos que foram produzidos, com os quais os sujeitos se identificam, tornando-se sujeitos na e pela língua(gem). Como analistas do discurso, tratamos as subjetividades a partir de suas relações com a memória, já que o sujeito do discurso se constitui a partir de sua relação com a língua e a história.

No entanto, é possível que o sujeito atualize essas significações, com formulações em que a polissemia estabelece a ruptura do já-estabelecido, que é o que observamos em nosso material. Os modos de formulação, constituição e circulação dos recortes desta pesquisa dão espaço à polissemia, a sentidos outros sobre a mulher que ultrapassam e rompem com uma memória discursiva. Assim, há denúncia das contradições e reivindicação de que a mulher e seu corpo possam ocupar o espaço público. Os pensamentos de Pêcheux tornam-se ideais para 
observar esse movimento, já que o teórico o toma como aquilo que falha no ritual ideológico e que constitui a possibilidade da resistência a um dizer, materializando-se na metáfora e na poesia das obras que aqui trabalhamos.

Sendo assim, trabalharemos com um corpo que é atravessado pelo inconsciente, pela história e pela língua. Corpo que comporta, portanto, uma memória de desigualdade, imposição, violência e opressão. A poesia dos lambes, sua brincadeira com as palavras, fura e aponta para a errância dos sentidos dominantes, deflagra o funcionamento político em que o poeta, ao fazer furos na língua, joga com o equívoco, fazendo aparecer o ponto do impossível (linguístico) e da contradição (histórica). Segundo Pêcheux ([1978] 1988), o processo metafórico se relaciona com o processo revolucionário, na medida em que desloca as evidências, desloca e transgredi um sentido que se metaforiza, que o político se coloca em toda sua força, pela via do poético. 
Figura 19 - Postagem do perfil @lela.brandao no Instagram em 08/06/2017

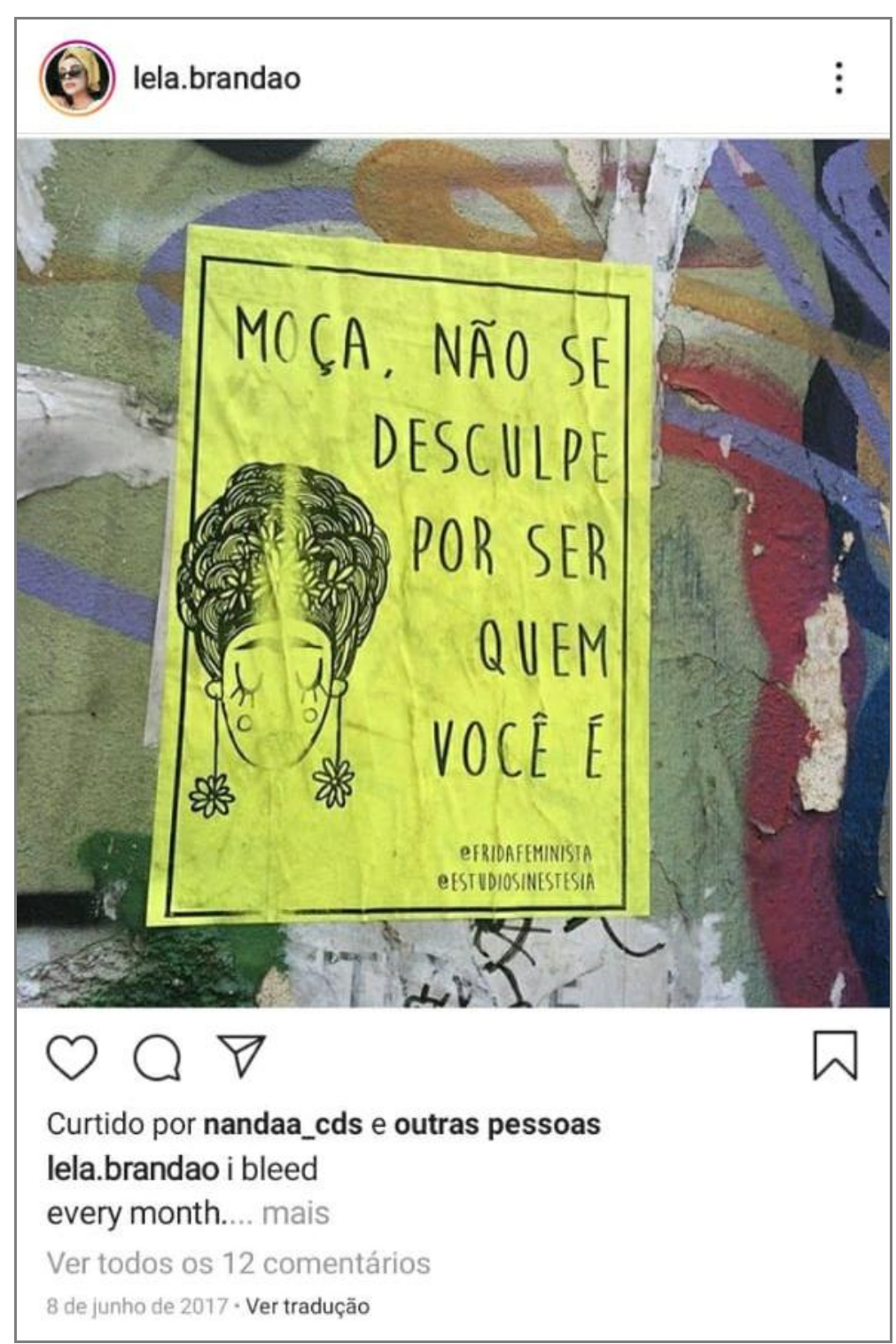

De acordo com Pêcheux (2008[1983]), a estabilização dos sentidos decorre de processos de desestruturação e reestruturação nas redes de memória, havendo então um embate da ideologia no interior da língua que afeta a forma como determinados sentidos/dizeres são reproduzidos, enquanto sentidos outros são silenciados, condizentes com os interesses da ideologia vigente

Pela negativa expressa por "Não", na figura 19, exposta acima, observamos que os dizeres-sentidos que se materializam no lambe-lambe garantem a possibilidade de atualização de um dizer via re-formulação de uma memória sobre o feminino, e aqui mais especificamente sobre a mulher e o seu corpo. Assim, por processos de desestruturação -

\footnotetext{
${ }^{17}$ Recuperado de https://www.instagram.com/p/BVGX1AfgxI_/
} 
reestruturação da memória, inerentes ao funcionamento discursivo, tal enunciado promove gestos de resistência à ideologia dominante, ainda hegemonicamente machista, abrindo novas possibilidades de ser sujeito e mais particularmente, mulher em sociedade. Dentre as possibilidades de ser mulher, os dizeres que se materializam no lambe-lambe, figura 20 , ressaltam o direito da mulher-ser, em contraposição a uma eterna busca do vir-a-ser a partir de determinados padrões.

Figura 20 - Postagem do perfil @ lela.brandao no Instagram em 25/04/2017 18

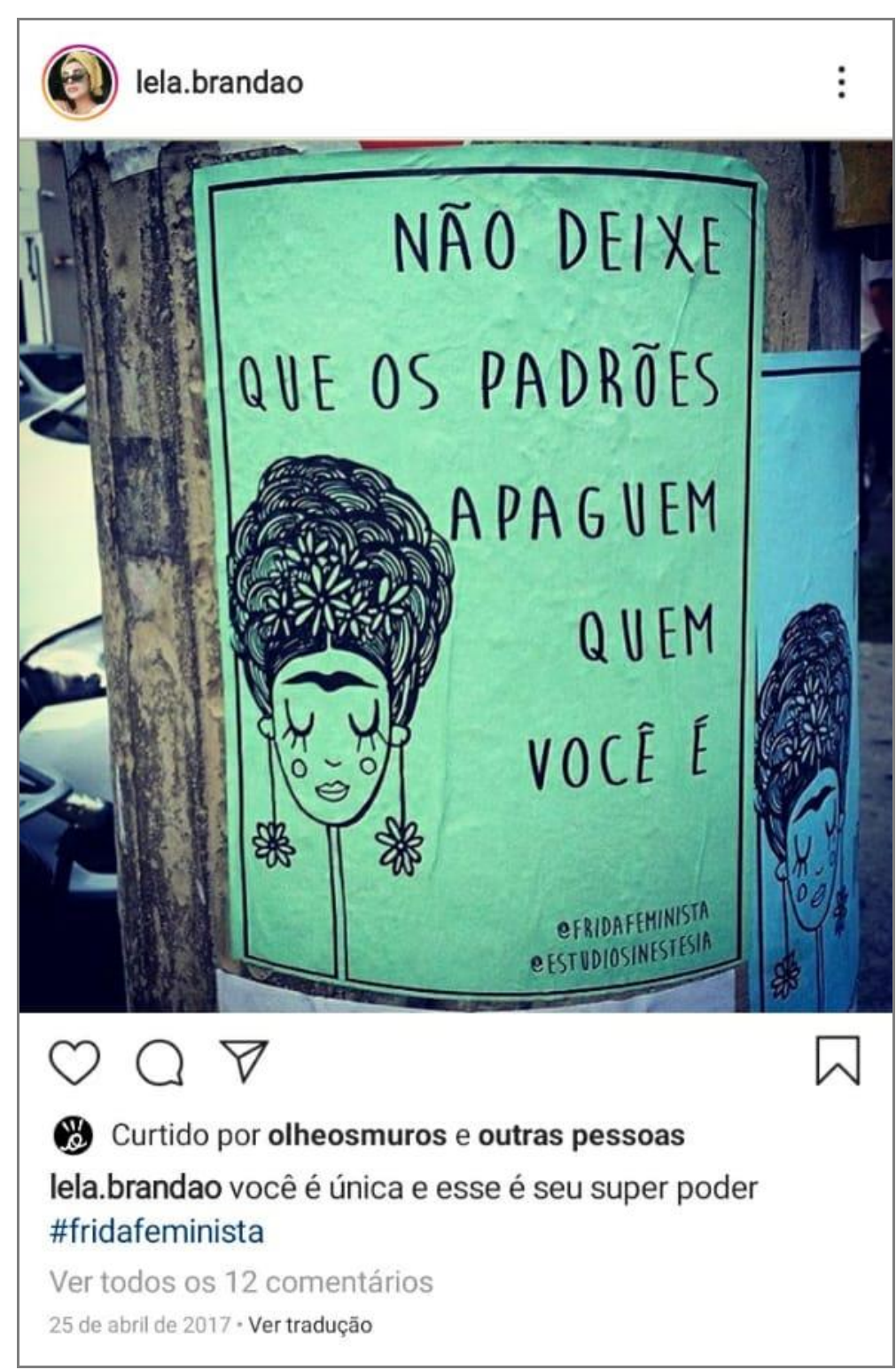

Embora a interpelação ideológica seja condição para ser sujeito, segundo Pêcheux (1975), há sempre possibilidades de resistência, visto que é inerente ao sujeito, na medida em

\footnotetext{
${ }^{18}$ Recuperado de https://www.instagram.com/p/BTU4UAUgoZi/
} 
que "o que está em jogo é a identificação pela qual todo sujeito se reconhece [...] e como é organizada sua relação com aquilo que o representa" (Pêcheux, 2010 [1969], p. 247). Historicamente, o corpo feminino é discursivizado a partir de uma regularização de determinados padrões estéticos (a serem) desejáveis: uma mulher docilizada, com o frescor da jovialidade, curvilínea. Entretanto, observamos na figura 20, supracitada, uma desnaturalização desses sentidos, proporcionando não só uma denúncia da tentativa de apagamento que há no seio social sobre as diferentes formas de /do ser mulher, como também uma convocação, entendida pelo imperativo no enunciado "Não deixe...". Por meio dela, há uma (nova) ordem que traz à mulher o direito de ser si mesma, que a convoca à sua subjetivação, ao seu desejo, fazendo emergir a possibilidade de (se) amar. É o que podemos observar na figura 21 a seguir. 
Figura 21 - Postagem do perfil @lela.brandao no Instagram em 07/12/2016 ${ }^{19}$

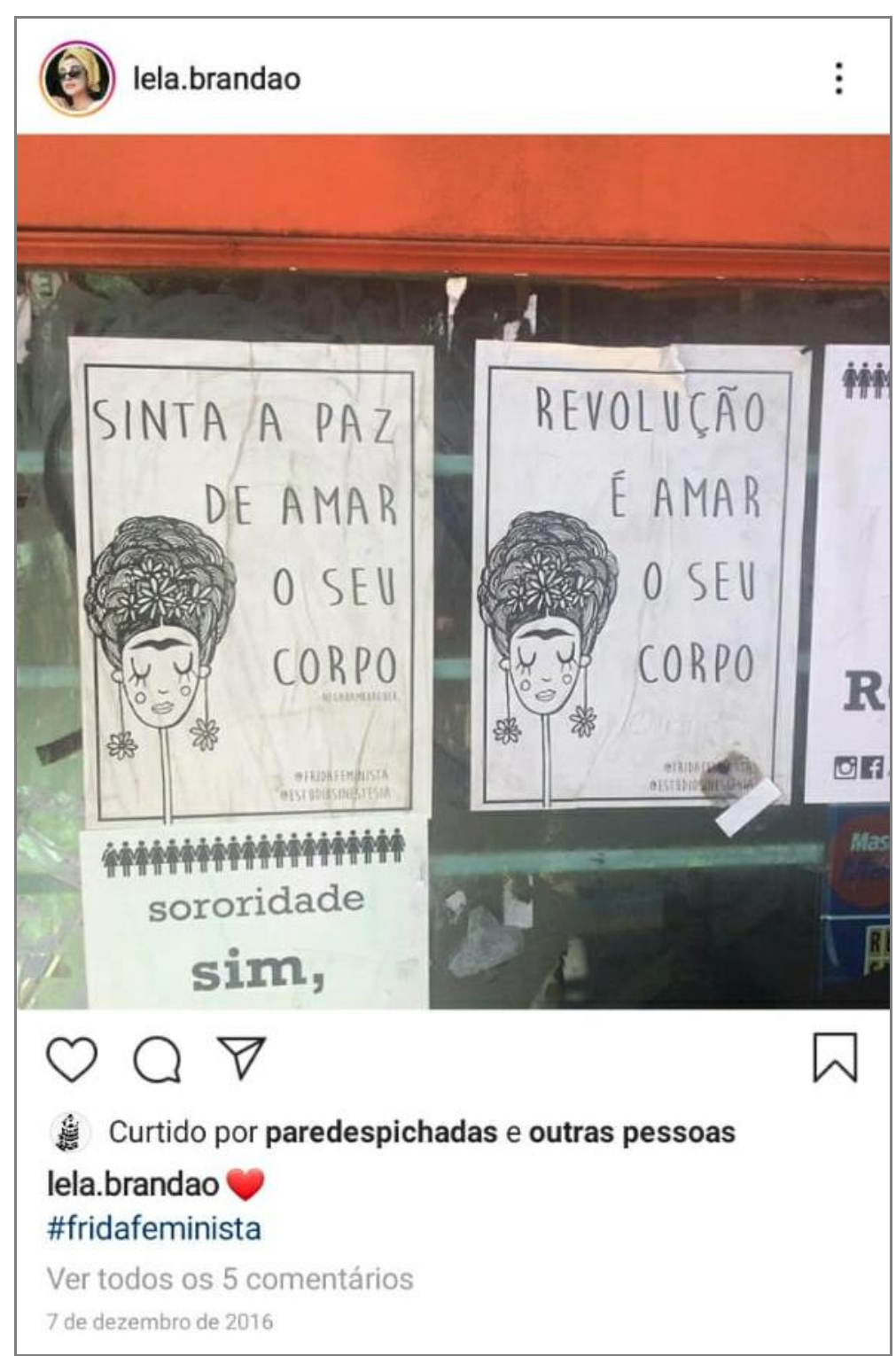

Em ambas as obras postas na figura 21, podemos perceber sentidos de uma possibilidade de inadequação de corpo em sociedade, bem como um sentido de que algo é dito que falta ao corpo quando não presente em um estereótipo, simbolizando ali um ideal de corpo e perfeição que circula em sociedade. Assim, as obras expõem um corpo que se expõe e denúncia, não só sentidos postos na história, mas, também, condições de produção nas quais esse ainda se percebe inserido, criando então um corpo discursivo que busca criar uma outra discursividade. Segundo Orlandi (2006, p. 6), “o desejo da constituição de outra forma sujeito, resultando em outras formas de individuação". Sendo assim, por meio desses novos sentidos que as obras tendem a fazer circular novas formas de ser sujeito em sociedade,

${ }^{19}$ Recuperado de https://www.instagram.com/p/BNu9ZX8gFHv/ 
fazendo assim um atravessamento do jogo político e social acerca do corpo feminino, já que as obras transparecem não se identificar com sentidos que solidificam estereótipos e rótulos acerca da mulher e seu corpo.

Orlandi (2009), em sua obra "Análise de discurso: princípios e procedimentos", teoriza que todo funcionamento da linguagem se baseia na articulação entre processos parafrásticos e polissêmicos. Pelos processos de paráfrase, podemos entender aqueles dizeres que se mantém ao longo da história, ou seja, a memória discursiva que se mantém. Já em relação aos processos polissêmicos, podemos compreendê-los a partir de todo dizer que causa o efeito de sentido de ruptura e deslocamento de sentido. Essas duas formas atuam de maneira contínua de modo que todo discurso é formulado a partir de uma ruptura e uma preservação do que já foi dito (Orlandi, 2009).

Se o real da língua não fosse sujeito a falha e o real da história não fosse passível de ruptura não haveria transformação, não haveria movimento possível, nem dos sujeitos nem dos sentidos. É porque a língua é sujeita ao equívoco e a ideologia é um ritual com falhas que o sujeito, ao significar, se significa. Por isso, dizemos que a incompletude é a condição da linguagem: nem o sujeito, nem os sentidos, logo, nem o discurso, já estão prontos e acabados. Eles estão sempre se fazendo, havendo um trabalho contínuo, um movimento constante do simbólico e da história. É condição de existência dos sujeitos e dos sentidos: constituírem-se na relação tensa entre paráfrase e polissemia (Orlandi, 2009, p. 37).

Nesse sentido, podemos compreender que a construção dos sentidos ocorre de forma contínua e que tal fato só ocorre pela inscrição dos dizeres no decorrer da história, na língua e no jogo entre paráfrase e polissemia. Ainda de acordo com Orlandi (2009, p. 38), “todo dizer é ideologicamente marcado. É na língua que a ideologia se materializa. Nas palavras dos sujeitos”. De tal modo, é imprescindível que, durante os gestos de análise, ocorra um esforço em compreender como o político e o linguístico se relacionam na produção de sentidos.

A atenção para aos conceitos de paráfrase e de polissemia permite um exercício de visualização da evolução dessa materialidade significante ontem e hoje. Assim, esta evolução torna-se mais evidente àquele que deposita seu olhar analítico aos confrontos políticos e históricos existentes em determinadas formações discursivas. O jogo entre os sentidos já estabilizados e o diferente fazem parte do funcionamento do discurso em rede, e as inscrições a partir de sentidos diferentes só são possíveis de serem percebidas pela movência da língua, que se dá nas materialidades. Para percebermos esse funcionamento, observamos os seguintes materiais: 
Figura 22 - Postagem do perfil @ lela.brandao no Instagram em 10/01/201720

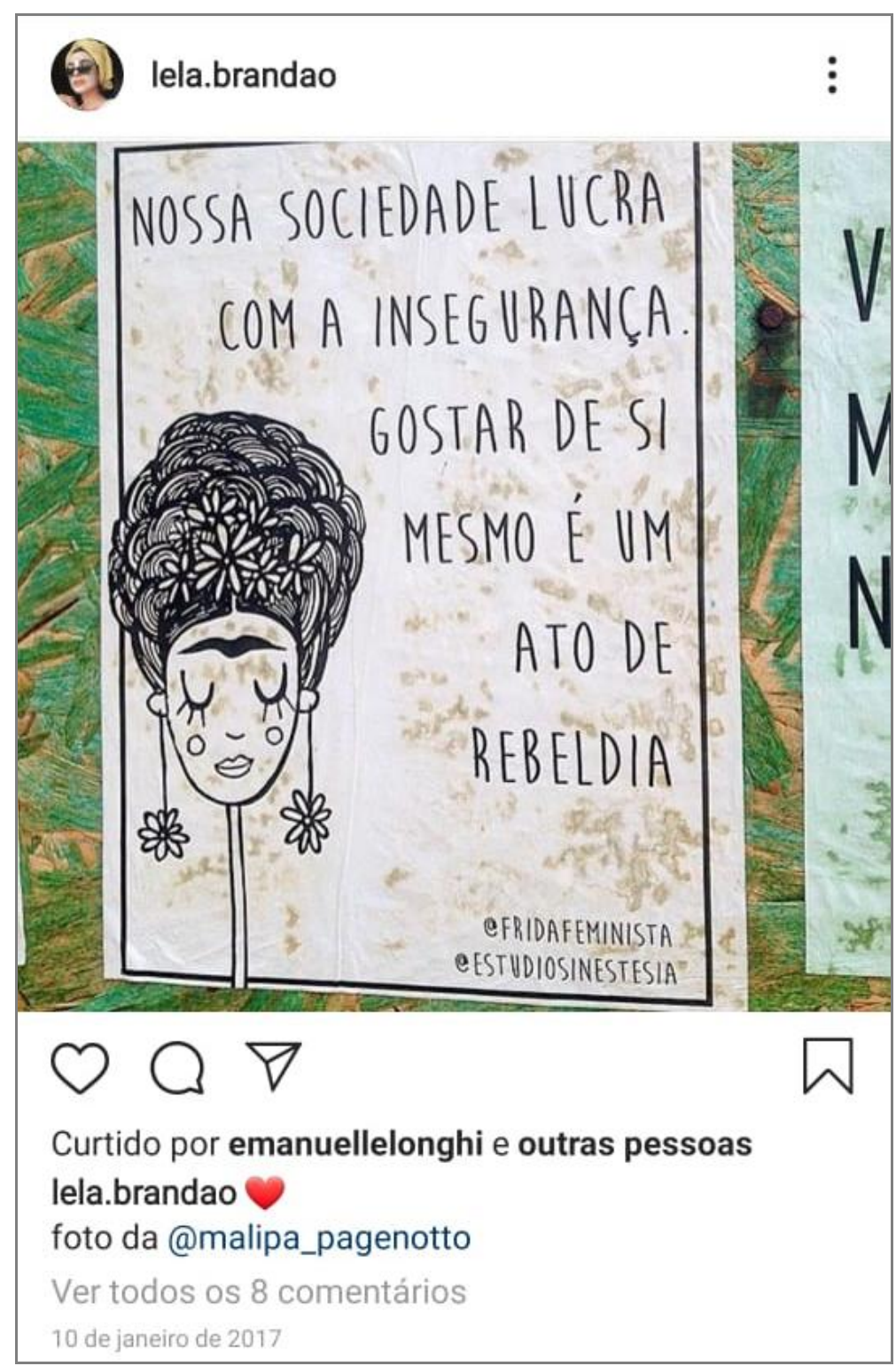

${ }^{20}$ Recuperado de https://www.instagram.com/p/BPGefwog58q/ 
Figura 23 - Captura de tela da página do Projeto Encontrarte no Facebook

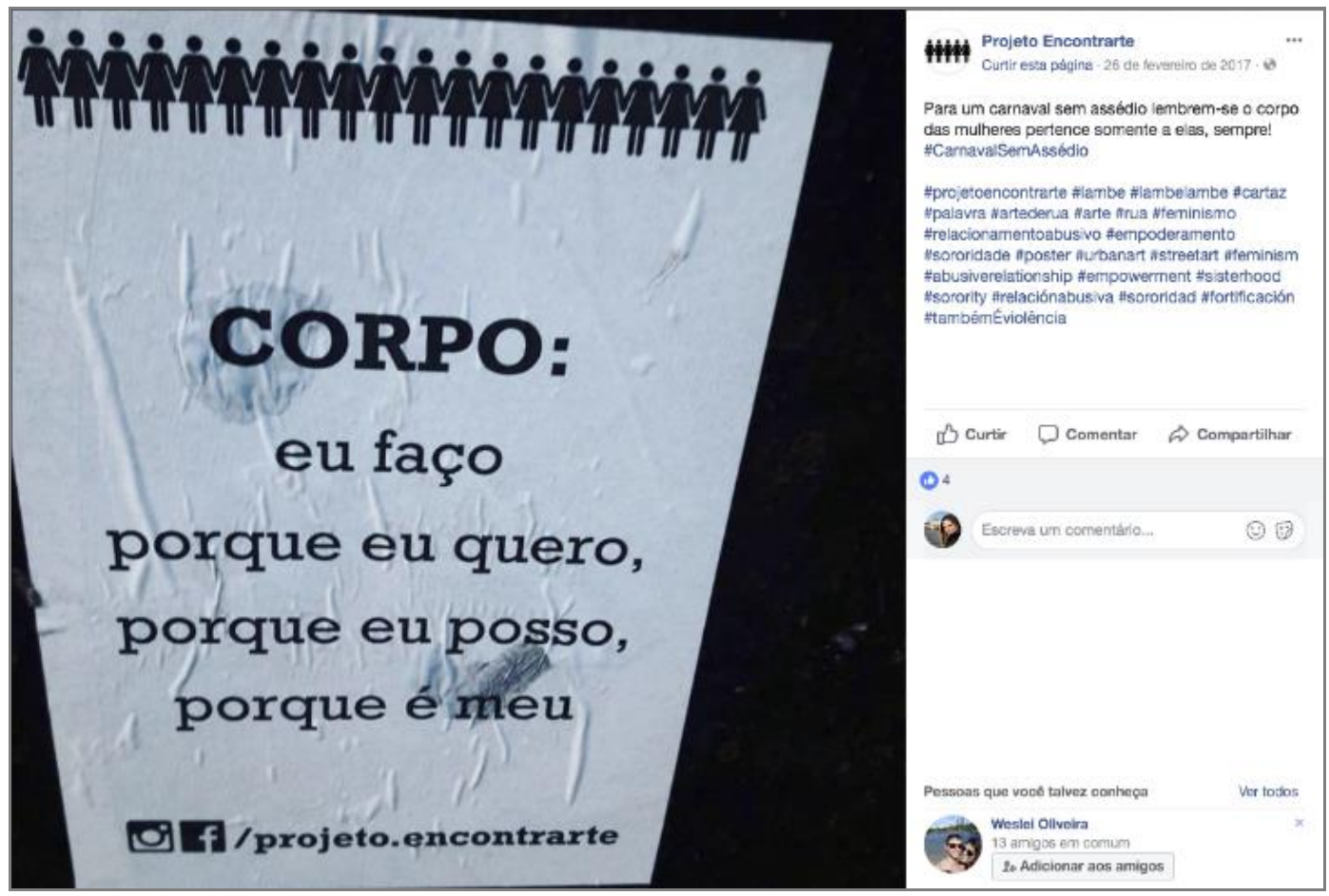

Nestes recortes, podemos analisar sentidos de um resgate da individualidade do sujeito-mulher, assim como nos aponta para a ilusão no dizer de que o sujeito é o senhor do que diz, devido aos esquecimentos - ilusões - $\mathrm{n}^{\circ} 1$ (de que não é origem de seu dizer) e $\mathrm{n}^{\circ} 2$ (que não controla o que diz) Assim, o sujeito toma seu desejo e o seu corpo (e os sentidos nele presente) como evidentes. Ou seja, o sujeito tem a impressão de que seu dizer, pensamento e desejo iniciam-se em si próprios, não havendo quaisquer influências. No entanto, o sujeito não é livre para dizer o que quer, já que sofre influência do contexto sócio, histórico e ideológico no qual vive, como também de seu inconsciente.

A formulação posta na figura 23 trabalha com a repetição para produzir um efeito de insistência e determinação com relação ao sujeito mulher enquanto dono de sua morada: "êu faço, porque eu quero, porque eu posso, porque é meu", alinhando os verbos fazer, querer e poder à ilusão de corpo e desejo próprio. Segundo Bocchi, Herculino e Lozano (2018), essa formulação sustenta a ideia de um sujeito que é articulado à sua vontade e à consciência espontânea, das quais o sujeito mulher é livre e capaz para gozar de seu corpo sem resistência, como um direito. Inscreve-se, então, um imaginário de sujeito livre e responsável pelo seu corpo e vontades, produzindo um efeito de completude e unidade. Assim, a formulação posta neste recorte interpela o sujeito-mulher que se depara com ela, convocando-o a ocupar sua posição de livre-arbítrio frente a seu corpo, sendo, assim, um ato de rebeldia frente aos sentidos estabilizados, como bem colocado na figura 22 , que retoma a questão de que ao se 
posicionar discursivamente contra os sentidos pré-estabelecidos, efetuará um gesto de resistência aos sentidos dominantes, posicionando-se como "rebelde".

\subsection{Um corpo que circula entre o público e o privado}

Tomaremos nessa subseção cinco recortes de materialidades postas em circulação no perfil do Projeto Encontrarte (@projeto.encontrarte), para nossa análise. Todavia, antes de delineá-la, acreditamos ser importante considerar como o projeto se nomeia, utilizando-se de um neologismo em que duas palavras se encavalam (encontro e arte), produzindo o efeito de sentido de um encontro com a arte ou até o de "te encontra" ou "te encontrar" produzindo um efeito de sentido de que é possível encontrar com outras mulheres ali, assim como, com os sentidos de (r)existência do feminino, na história, pelo digital.

Tal encontro não se apresenta a partir de um nome próprio de autor da conta ou das obras, mas por um plural de pessoas que se constituem enquanto um projeto. Assim, tal conta se apresenta enquanto um gesto discursivo de um grupo e não somente de um indivíduo, sendo, então, um gesto de denúncia de muitas mulheres.

Figura 24 - Postagem do perfil @ projeto.encontrarte no Instagram em 02/04/2018 ${ }^{21}$

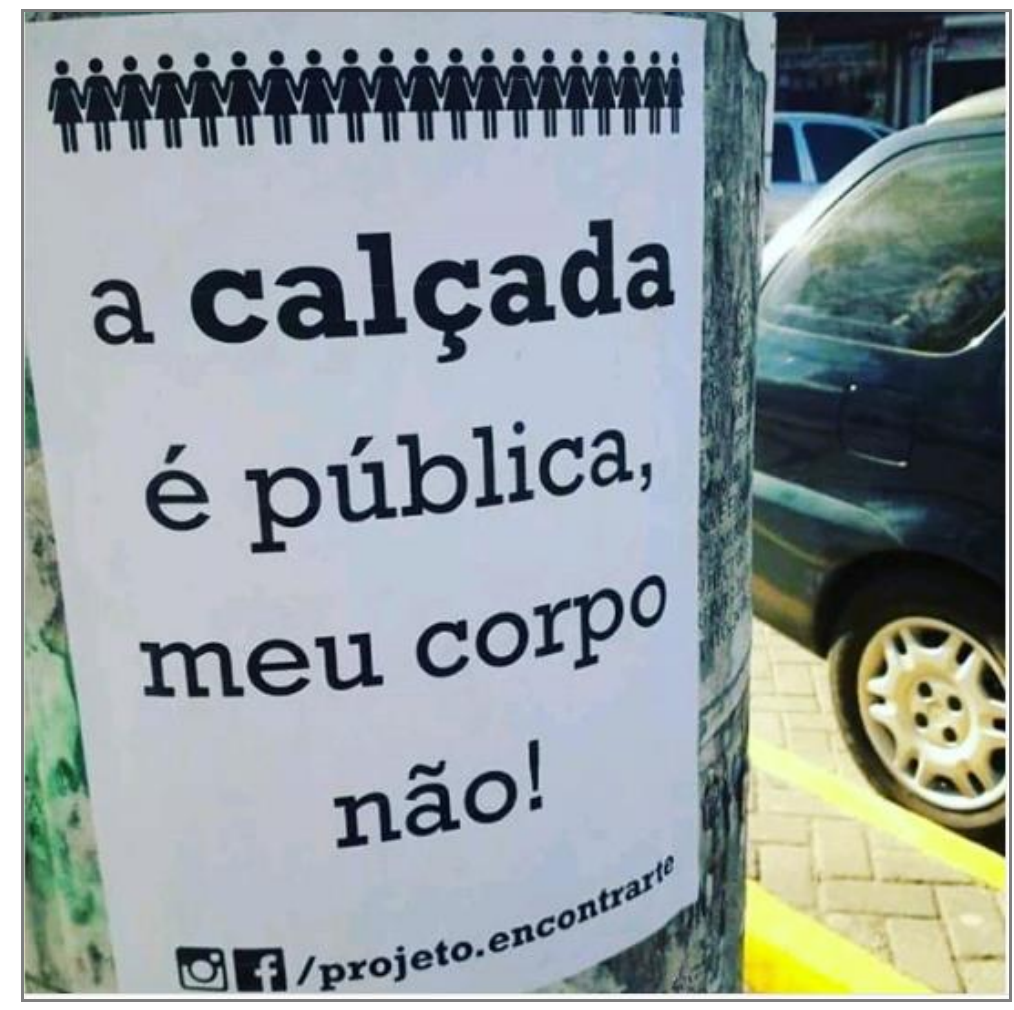

\footnotetext{
${ }^{21}$ Recuperado de https://www.instagram.com/p/BhFW6nD17GX/
} 
Figura 25 - Postagem do perfil @ projeto.encontrarte no Instagram em 01/12/201722

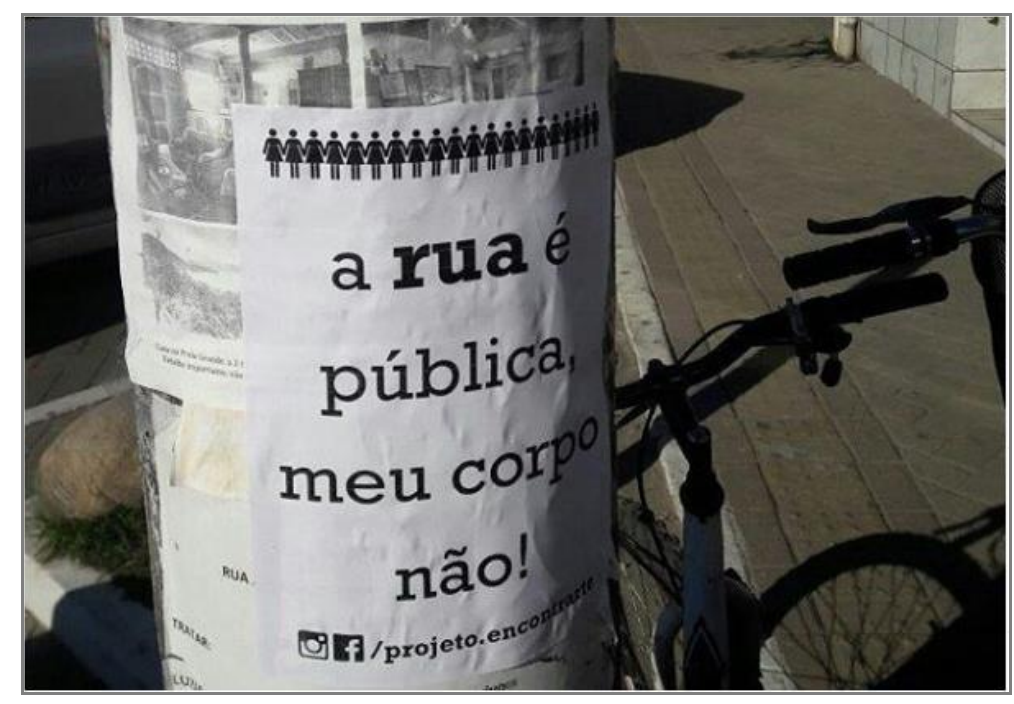

Figura 26 - Postagem do perfil @ projeto.encontrarte no Instagram em 31/08/201723

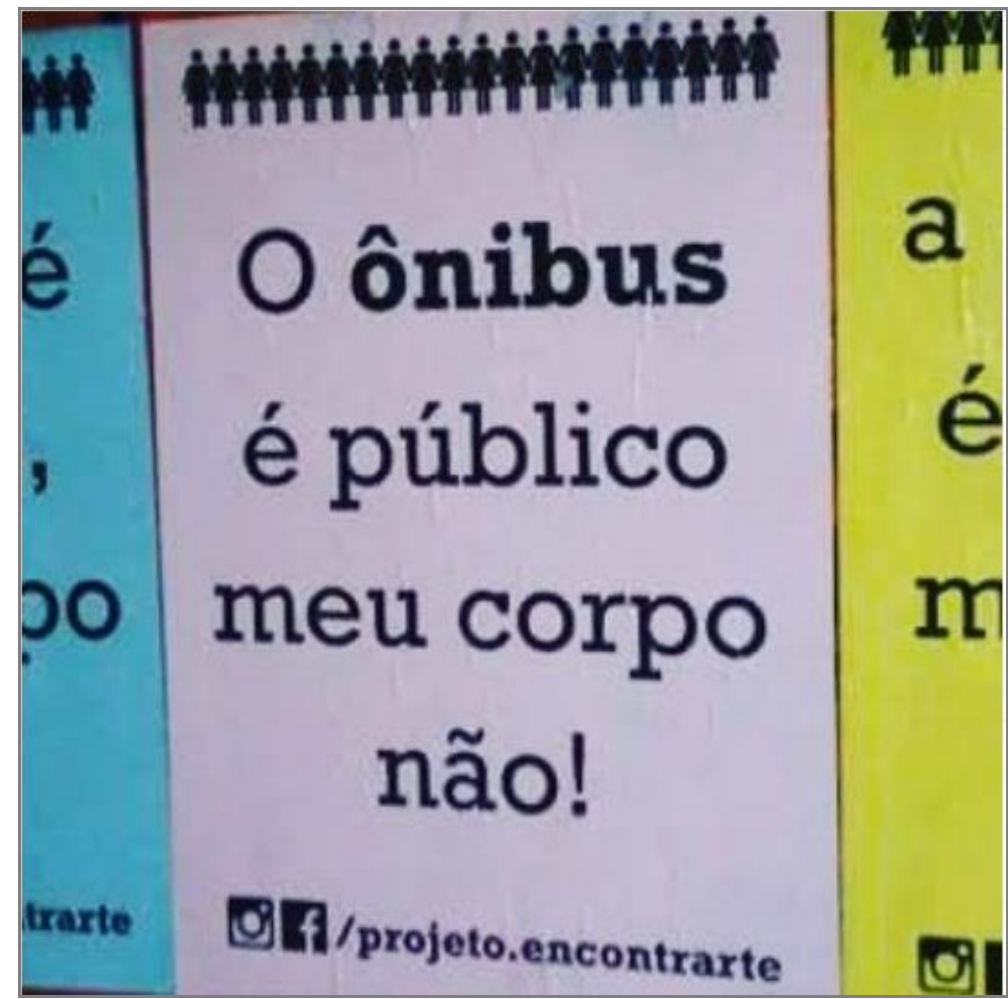

Nesses três primeiros recortes, Figuras 24,25 e 26 respectivamente, observamos a forma como cidade e sujeito se significam. Como já posto nessa pesquisa, as relações com o urbano são compreendidas pela $\mathrm{AD}$ como relações de sentido, e essas se materializam nos recortes acima produzindo efeitos de sentido em que o corpo feminino, ao circular no espaço

\footnotetext{
${ }^{22}$ Recuperado de https://www.instagram.com/p/BcLCn2mlTmt/

${ }^{23}$ Recuperado de https://www.instagram.com/p/BYeAUiwFUFy/
} 
público, torna-se também público, sujeito a ser molestado e violentado, estabelecendo, então, nas obras um efeito de denúncia. Ao se repetirem os enunciados (“a... é pública, meu corpo não"), vemos uma produção de sentidos que desestabiliza e desorganiza os sentidos estereotipados pela ideologia acerca do corpo da mulher no espaço público, levando-nos a pensar que tais formulações constituem um acontecimento, pois desestabilizam uma memória social que coloca a circulação da mulher na cidade, na rua, como a circulação de um corpo público, produzindo uma deriva de sentidos. Segundo o autor fundador da $\mathrm{AD}$, a memória social seria:

aquilo que, face a um texto que surge como acontecimento a ler, vem restabelecer os implícitos ${ }^{\text {ee }}$ (quer dizer, mais tecnicamente, os pré-construídos, elementos citados e relatados, discursos-transversos, etc.) de que sua leitura necessita: a condição do legível em relação ao próprio legível (Pêcheux, 2020 [1983], p. 48, grifo nosso).

A partir disso, pelo funcionamento da memória, é possível recuperarmos já-ditos em nossa história, a partir de uma formação do discurso que produz a materialidade de uma memória discursiva no texto. Essa materialidade é constituída historicamente e se atualiza no discurso dos lambes por uma outra forma de dizer sobre a mulher e seu corpo no espaço público, gerando sentidos que ainda são atravessados pelo/no discurso outro, o já-dito.

É importante colocar que, aqui, não tratamos de uma memória individual, conforme a trabalhada pela psicologia, mas, sim, de uma memória social. Esta é construída pela/através (d)a história, memória discursiva (Pêcheux, 2010), formulada como “[...] a morada dos sentidos" (Leandro-Ferreira, 2012, p. 141), sendo então uma memória que é anterior ao sujeito e que o atravessa, presente nos discursos atuais. Como Robin (2016) aborda em seu texto, o passado não é deixado à deriva, ele é "regido, gerido, preservado, explicado, contado, comemorado ou odiado" (p. 31), assim, memória de posto, enquanto um corpo público, não pertence ao próprio sujeito, mas nos traz pelos fios da memória, sentidos de um passado que é, ainda hoje, "celebrado ou ocultado, permanece uma questão fundamental do presente" (Robin, 2016, p. 31).

Segundo Kehl (2016) a inscrição dos sujeitos (independentemente de gênero) no discurso de nossa sociedade incidem por modificações que afetam a estrutura da linguagem e por sua vez os usos da língua e, com isso, o lugar que a cultura irá atribuir certos sentidos determinados aos sujeitos. Esse lugar depende principalmente das práticas discursivas, uma vez que possibilitam rupturas, deslizamentos, deslocamentos de sentidos e, por conseguinte, a ressignificação das posições dos sujeitos nas práticas sociais. Os sentidos não se fixam aleatoriamente, mas se regularizam na esfera social a fim de se materializar nas práticas dos 
sujeitos. Trabalho esse da ideologia que, pela via da interpelação ideológica aos sujeitos discursivos, opera a fim de convocar os sujeitos a ocupar os seus lugares, pré-determinados ideologicamente, na esfera social (Althusser,1967).

As obras que analisamos nos fornecem em suas materialidades discursivas uma forma de compreender o modo de funcionamento da ideologia tanto na regularização de um imaginário de mulher, como para o rompimento deste imaginário por sua ruptura através da cibermilitância.

Nos recortes das figuras 24, 25 e 26, a analogia entre o corpo do sujeito e o corpo da cidade trabalha a partir de um jogo com a memória. Ao se realizar uma repetição dos sentidos “a...é pública, meu corpo não" ou “o ônibus é público, meu corpo não” o texto não reproduz um estereótipo, pelo contrário, o atravessa, deslocando os sentidos. Segundo Bocchi, Herculino e Lozano (2018), há nesses recortes a contestação da ideia de que o corpo feminino, ao despontar no espaço público, torna-se também público, sendo por direito algo a ser desfrutado por todos os cidadãos, assim como a rua, a calçada e o ônibus. Com efeito, com o enunciado "a rua é pública, meu corpo não", podemos refletir que há um resgate a uma memória sobre a mulher nas esferas públicas e privadas que Chaves (2015) delineia como a relação social existente entre a mulher da rua (prostituta) e a da casa (“do lar”). A partir disso, nesse encontro entre a atualidade ("lugar de mulher é onde ela quiser") e uma memória (mulher de rua é prostituta), acontece uma tensão que desestabiliza esse dizer, desencadeando um novo, tanto sobre a rua, quanto sobre o corpo feminino.

Assim, as formulações apontadas nos três recortes acima circulam sentidos outros, defendendo que o corpo feminino não condiz com a esfera pública, já que, segundo Antunes (2018), o sentido de público é o de que tudo que ali está acessível a todos. Temos então uma discursividade que nega o corpo como objeto público a ser desfrutado. A partir disso, vemos que a rua investe no corpo feminino de sentidos através de um resgate de memória sobre a mulher nas esferas pública e privada que Chaves (2015), em seu trabalho, desenvolve como uma relação de discursividade entre a mulher da rua (prostituta) e a mulher da casa (recatada, "rainha do lar"). Para a autora, retomando uma historicidade acerca de como a mulher era discursivizada "instalava-se, então, um sistema de verdades para a mulher urbana, higienizada, de sociabilidade moderada com a noção de honestidade intimamente ligada ao governo da sexualidade" (Chaves, 2015, p. 71). As obras surgem, então, como uma materialidade que nos aponta para uma memória que atravessa o futuro e faz furo. 
Embora surja uma nova conjuntura, um novo horizonte de expectativa, uma nova sede de fundação, nós o apagamos, esquecemos, remetemos à frente de outros episódios, voltamos, reescrevemos a história, inventamos, em função das exigências do momento e das antigas lendas (Robin, 2016, p. 31).

Cabe salientar que essas obras foram produzidas no final do ano de 2017, época em que, no Brasil, houve um aumento significativo do número de casos de abuso e assédio sexuais cometidos nos transportes públicos ${ }^{24}$. Com esses eventos, houve a percepção de que a legislação penal brasileira (Brasil, 1940; 1941) ${ }^{25}$ não contemplava casos como esse pela dificuldade em se caracterizar a prática de violência ou grave ameaça, o que impossibilitava o indiciamento, já que, muitas vezes, há uma dificuldade na interpretação da violência quando essa não é física. Assim, por meio da Lei n 13.718, de 24 de setembro de 2018 (Brasil, $2018)^{26}$, houve a tipificação dessas condutas como, por exemplo, a “importunação ofensiva ao pudor”. Seguindo, então, para materialidades do nosso corpus que também trabalham com os sentidos do corpo feminino enquanto propriedade pública, podemos perceber nesses recortes o uso da equivocidade da língua, ao brincar com o significante público, estabelecendo outros sentidos para o corpo da mulher em sociedade.

Figura 27 - Captura de tela da página do Projeto Encontrarte no Facebook

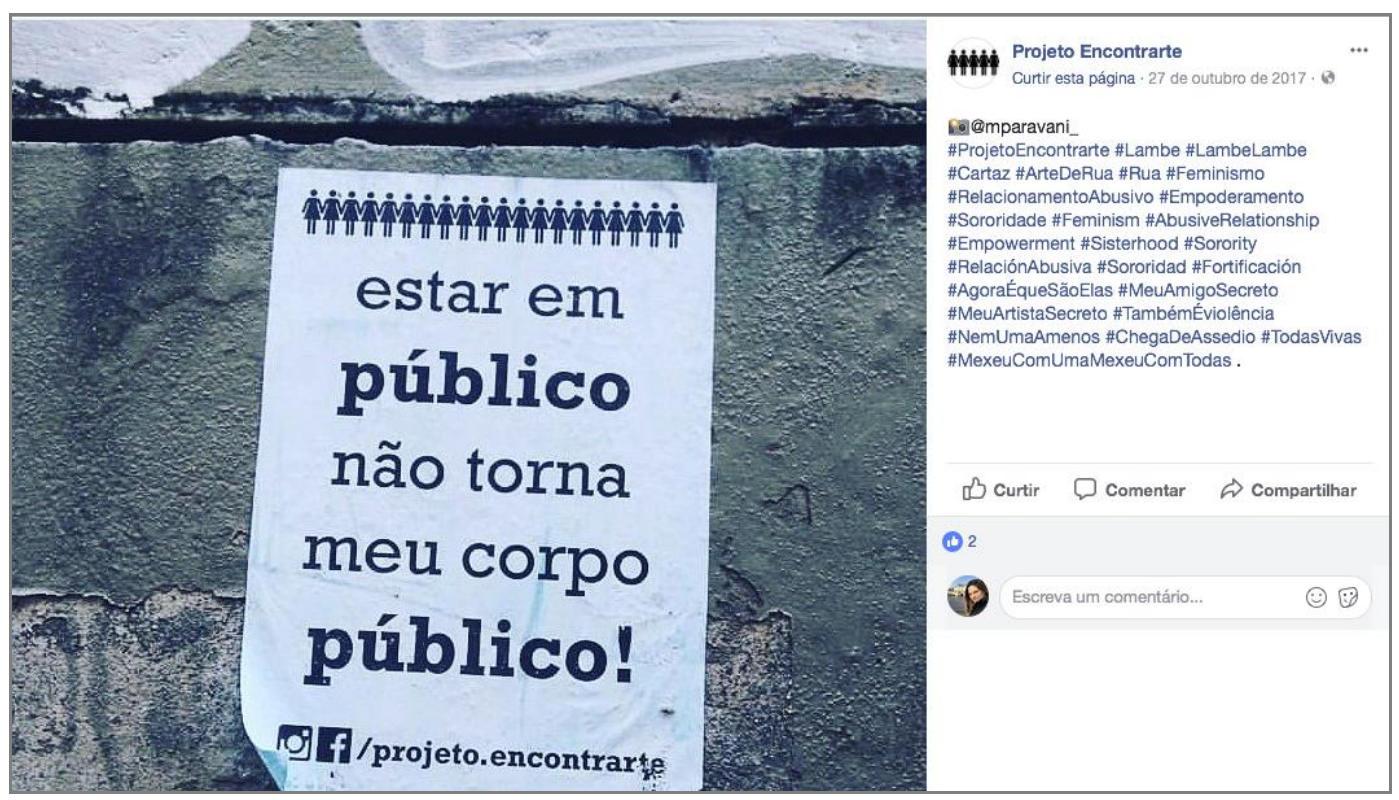

\footnotetext{
${ }^{24}$ Cf. Mendonça (2017).

${ }^{25} \mathrm{O}$ art. 61 da Lei das Contravenções Penais foi revogado pela Lei no 13.718 de 2018 (Brasil, 2018): “Art. 61 Importunar alguém, em lugar público ou acessível ao público, de modo ofensivo ao pudor: Pena - multa, de duzentos mil réis a dois contos de réis". (Brasil, 1941).

26 “Art. $1^{\circ}$ Esta Lei tipifica os crimes de importunação sexual e de divulgação de cena de estupro, torna pública incondicionada a natureza da ação penal dos crimes contra a liberdade sexual e dos crimes sexuais contra vulnerável, estabelece causas de aumento de pena para esses crimes e define como causas de aumento de pena o estupro coletivo e o estupro corretivo" (Brasil, 2018).
} 
Segundo Orlandi (2009, p. 37) “a língua é sujeita ao equívoco e a ideologia é um ritual com falhas que o sujeito, ao significar, se significa". Assim, brincando com a equivocidade própria da língua, ao utilizar a palavra "público", mas tomando-o como aquilo que possibilita (re)significar e resistir, percebemos que essa discursividade não se submete ao imaginário patriarcal, rompendo com sentidos de que o corpo da mulher, ao circular no público, é público. Tal formulação circula no poste e no post, sentidos que asseguram à mulher o direito à circulação no âmbito público, desestabilizando com os sentidos que rompem com a indistinção entre corpo do sujeito e corpo da cidade. Ao trabalhar com a repetição do termo público, no recorte da figura 27, retirando-o do significado comum, a formulação desse dizer marca um deslocamento na superposição sujeito e cidade ao significar que estar em público não torna o corpo da mulher público. Assim, esse jogo discursivo retira do funcionamento da língua, o estereótipo de mulher como aquela, no espaço público, que coloca seu corpo a ser desfrutado, meretriz. Deste modo, a formulação posta nessa materialidade rompe com o efeito do funcionamento do pré-construído (Pêcheux, 1975, p. 88), que antecipa uma relação de sentido a um elemento prévio não submetido à discussão, mas que se encontra na memória discursiva.

A nosso ver, portanto, a violência não é "natural" à cidade: ela se produz (pelas condições de vida social), é mantida (por políticas apenas repressivas e não formadoras de sociabilidade) e desencadeada (por soluções imediatistas) por processos de significação que são históricos e sociais. No entanto, há muito a ser significado no espaço urbano e que permanece na falha, no possível, no ainda não realizado. Indícios de novas formas sujeito, novos modos de subjetivação nesse espaço sócio-político. (Orlandi, 2012, p. 191).

Os lambe-lambes se inscrevem então nas falhas do espaço público, rompendo com sentidos historicizados e indiciando outros modos de subjetivação do sujeito mulher, que passa a ressignificar seu corpo no espaço sócio-político. Ao provocar um desarranjo nos sentidos pré-construidos, que seguem estereótipos ideológicos acerca do corpo da mulher, as materialidades que aqui nos debruçamos produzem um jogo discursivo que desestabiliza e transforma os sentidos formulados historicamente acerca do corpo feminino enquanto propriedade ou um corpo, quando na rua, em público. Assim, percebemos efeitos de sentido de um corpo objetificado que, quando circula na rua, é passível de ser abusado ou até comercializado. Deste modo, desestabilizam-se os sentidos pré-existentes na memória e essa desregulação perturba tais implícitos, sendo este o movimento realizado pelas militâncias em nossa contemporaneidade. 


\section{CONSIDERAÇÕES FINAIS}

Figura 28 - Obra da artista visual brasileira Nega Hamburguer

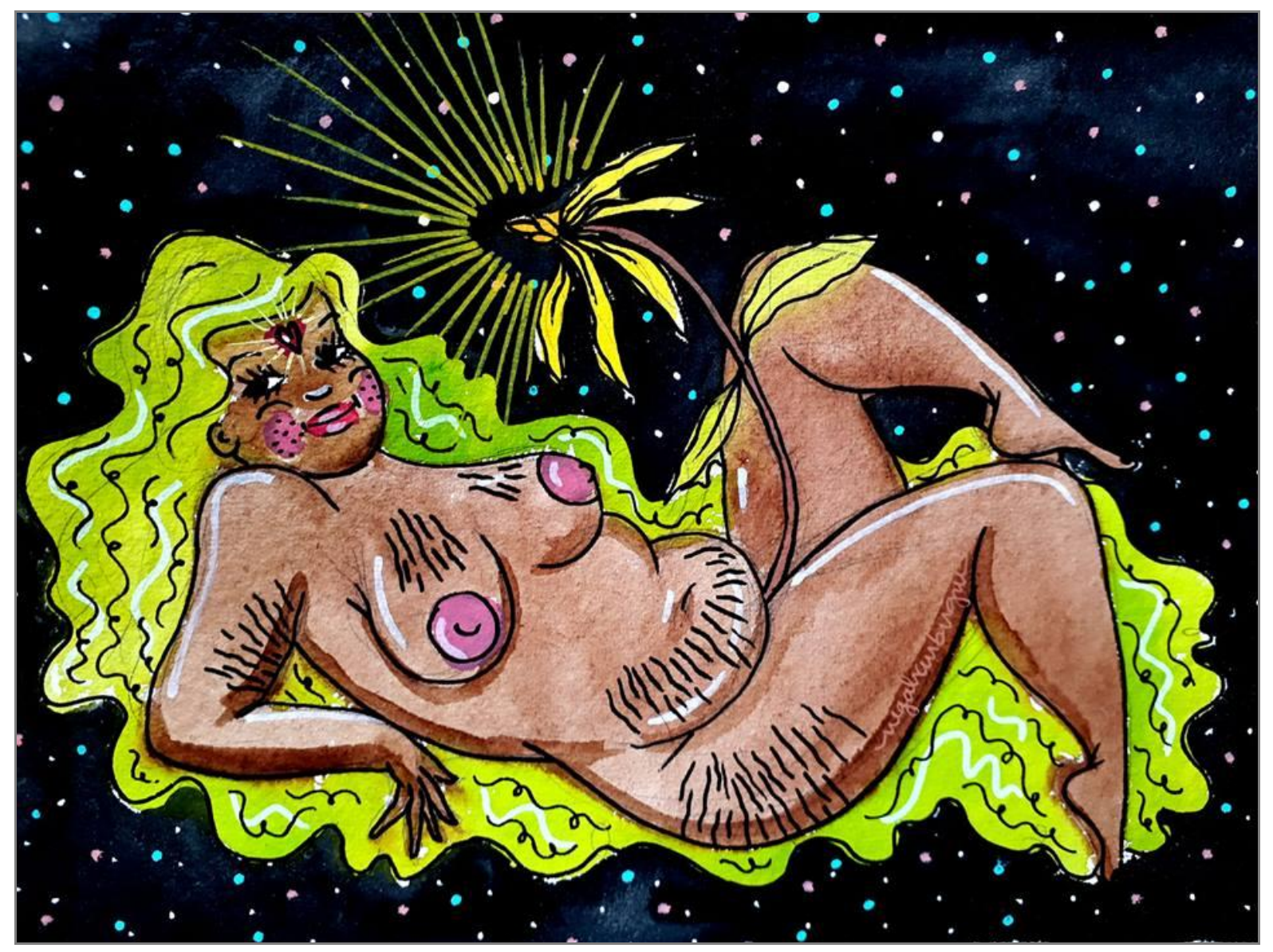

Fonte: https://nanu.blog.br/na-nuzeando-negahamburguer/

Vira a mesa, assume o jogo, faz questão de se cuidar. Nem serva, nem objeto, já não quer ser o outro, hoje ela é um também.

(Pitty, Desconstruindo Amélia) 
Realizamos, neste capítulo, um esforço de retomar as considerações feitas ao longo dessa pesquisa. Observamos que tanto a rua como o digital, de certo modo, determinam a relação do sujeito com o sentido. Assim, o que determina a formulação dos sentidos do lambe-lambe e da poesia que esse produz é o movimento da rede e da rua como movimentos de um espaço em-comum, onde essas instâncias se co(n)fundem, possibilitando a tensão entre o já dito e a possibilidade de dizer. Isso permite a retomada, a ressignificação e a atualização de um discurso, como também marca a natureza do singular do dizer e dos gestos de resistência. Levantamos como ponto de atenção o funcionamento do espaço em-comum entre rede e rua que esta materialidade se encontra, tendo este espaço o potencial de estabelecer uma organização de mulheres que vão tecendo relações de convívio, solidariedade e de produção de novos sentidos sobre a mulher.

A partir de nosso corpus, foi possível refletir sobre as lutas pela equidade de direitos e a desobjetificação do corpo feminino que ainda se promovem por meio de discursos regularizados. Sendo, assim, possível perceber gestos de resistência a sentidos que estabelecem um certo ideal de corpo à mulher, como também um chamado às mulheres ocuparem seu lugar em sua subjetividade. Problematizando questões em nosso contemporâneo que tomam (ou não) as subjetividades do feminino, enquanto uma evidência, composta de sentidos fixos, onde os sujeitos são fisgados por malhas discursivas, inscrevendo diversas práticas fixas, determinando o que cabe ou não a uma mulher fazer, sentir ou como esta deve ser colocar no mundo e de que forma. Assim, percebemos as obras que aqui analisamos realizando uma atividade de contextar sentidos ainda sendimentados

Também foi possível observar em nosso corpus as tensões que envolvem a presença de mulheres no espaço público e, por consequência, as derivas nos sentidos de corpo (feminino) público enquanto aquele que está posto ali como produto a ser utilizado e/ou comercializado, corpo de mulher que é depreciado, vulgarizado e cujo desejo, ou não, é apagado. As obras apontam para nós derivas de sentidos sobre a mulher, cujos efeitos se colocam na relação entre o que é público e o que é privado para a mulher e o seu corpo, ditado por meio de regras sociais que vão ao encontro da ideologia vigente (capitalista). Sentidos que en-formam e/ou excluem mulheres a partir de uma idealização do feminino.

A partir de nossos gestos de análise foi possível perceber a importância e a necessidade de se ouvir as vozes das mulheres em relação às questões que tangem o feminino e nossa contemporaneidade. Tomando os movimentos no digital, enquanto um local produtor e disseminador de dizeres, que resiste e que se opõe aos dizeres historicamente consolidados e construídos. 
Percebemos assim, a importância da materialidade significante das obras de lambelambe, observando que as reflexões não se encerram nas relações entre o espaço da rua e o feminino, mas também se ampliam para as redes. Em suas condições de produção, os sentidos que compõem os recortes analisados neste trabalho se produzem como resposta ao momento histórico no qual ainda nos encontramos, sendo este marcado por denúncias de assédio e invasão ao corpo da mulher no espaço público, os quais acarretaram inúmeras discussões sobre o limite da lei no entendimento do conceito de estupro ${ }^{27}$. Consideramos, então, que ao extrapolar os limites entre o virtual e o físico, o post e o poste, os lambes-lambes aqui analisados por meio dos recortes apresentados, (re)significam, também, os limites impostos para a mulher e(m) seu corpo, (re)inscrevendo sentidos outros tendo em vista o seu caráter privado.

A partir de nossas análises, percebemos que as obras de lambe-lambes surgem como formulações capazes de estabelecer redes de sentidos capazes movimentar os pré-estabelecidos sobre a mulher, estabelecendo uma relação de desidentificação com um dizer dominante que aborda a mulher e seu corpo. Dessa forma, com essa pesquisa, podemos dizer que atendemos aos nossos objetivos de perceber como o corpo feminino é discursivizado nas obras de arte de lambe-lambe que são compartilhadas em rede, bem como compreender como as configurações do digital dão corpo às relações dos sujeitos com os sentidos compartilhados em rede. Vemos que, ao retomar certas memórias, as obras de lambe-lambe denunciam como a sociedade ainda hoje violenta a mulher ao colocar seu corpo em posição de uso e apropriação pelo outro, assim como lhe impõe um padrão de corpo, impedindo também de circular no público o diferente. Assim, as obras também apontam para a denúncia do silenciamento sobre o desejo ou não da mulher perante o uso e a forma de seu corpo.

A Análise de Discurso se fez importante nesse trabalho por compreender que os sujeitos e os sentidos se constituem mutuamente na história, em consonância com as posições ocupadas no discurso. Assim, a materialidade do lambe-lambe, torna-se um material que, muitas vezes, é tido pelos sujeitos à margem da sociedade, que possibilita estes sujeitos (re)existirem por meio da arte, fazendo circular sentidos outros sobre o feminino.

Com isso, considerando a relevância das cibermilitância em nossa contemporaneidade este trabalhou buscou se lançar a uma leitura acerca da voz de mulheres, frequentemente silenciadas, propondo, assim, um novo olhar para as práticas sociais de militância digital, como, principalmente para a relação da mulher em nossa contemporaneidade e seu corpo. Acreditamos que, os exercícios teóricos e analíticos postos nessa dissertação puderam marcar

\footnotetext{
${ }^{27}$ Cf. Machado (2017).
} 
a singularidade nas formas de tomar o feminino e o corpo em nossa sociedade, apontando para a potência da arte e da (r)existencia no público, principalmente no que se refere ao movimento das redes digitais, rompendo e costurando os sentidos do feminino em nossa história. 


\section{REFERÊNCIAS}

Figura 29 - Obra da artista visual brasileira Nega Hamburguer

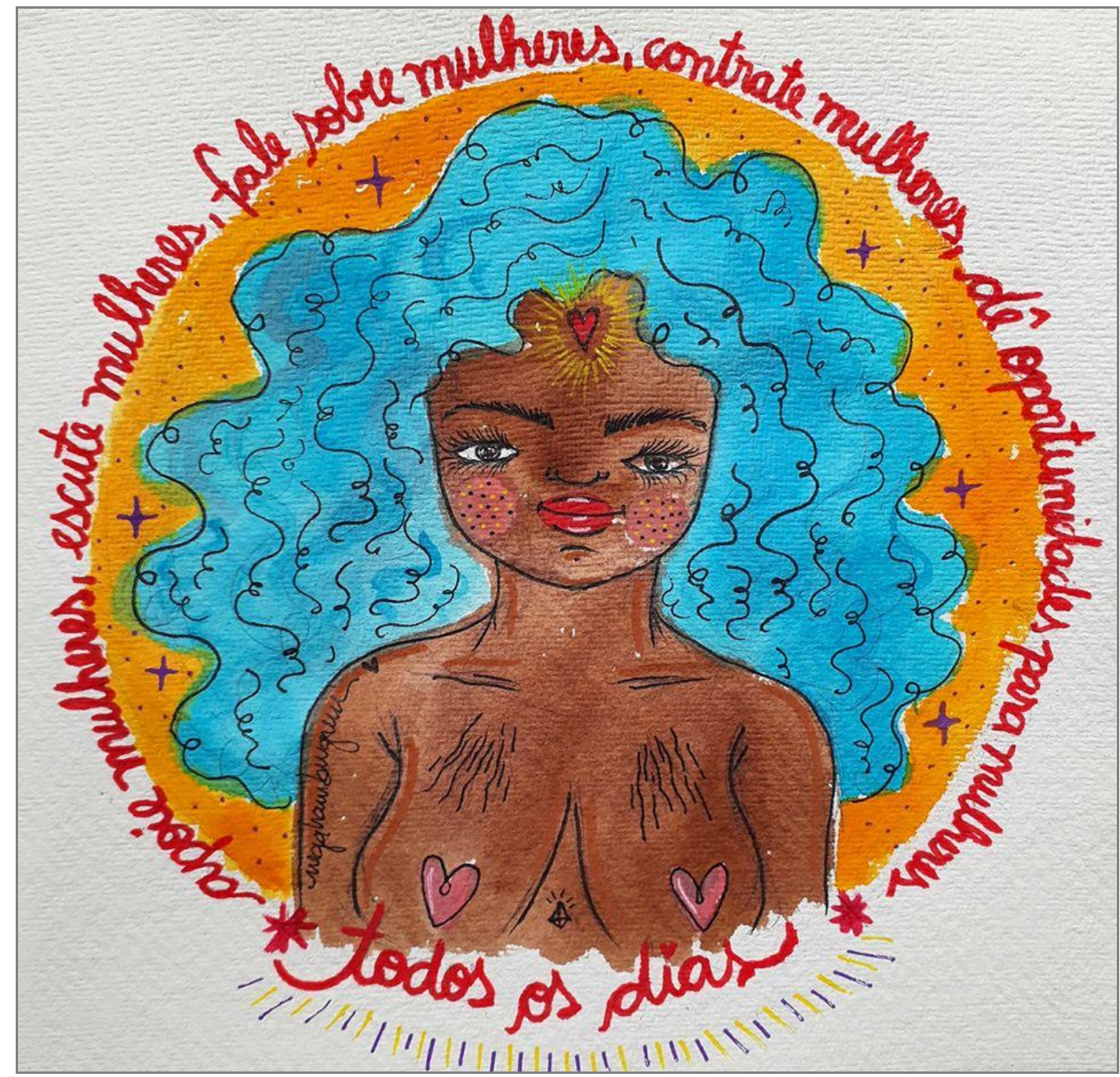

Fonte: https://nanu.blog.br/na-nuzeando-negahamburguer/

meu pulso acelera diante da ideia de parir poemas e é por isso que nunca vou parar de me abrir para concebê-los o amor pelas palavras é tão erótico que estou apaixonada ou excitada pela escrita ou ambos 
Althusser, L. (1970). Ideologia e Aparelhos ideológicos do Estado. Lisboa: Presença.

Alvarenga, M. A. \& Rosa, M. V. F. P. (2003). Apontamentos de metodologia para a ciência e técnicas de redação científica. (3a ed. rev. e ampl.). Porto Alegre: Sergio Antonio Fabris Editora.

Antunes, M. A. (2018). O público e o privado em Hannah Arendt. Recuperado de http://www.bocc.ubi.pt/pag/antunes-marco-publico-privado.pdf

Bastos, G. G. (2018). Os sujeitos-gays nas tramas da(s) rede(s): o discurso sobre os aplicativos de relacionamento. Tese de Doutorado, Faculdade de Filosofia, Ciências e Letras de Ribeirão Preto, Universidade de São Paulo, Ribeirão Preto. DOI: 10.11606/T.59.2018.tde-25082018-224849

Bocchi, A. F. A., Herculino, B. M. \& Lozano, M. F. (2018). O corpo inscrito pela arte urbana: militância e autoria entre o público e o privado. In T. M. Campos \& L. M. A. Sousa (org.). Mídias e movimentos sociais (pp. 35-53). São Carlos: Pedro \& João Editores.

Bogdan, R. \& Biklen, S. K. (1994). Investigação qualitativa em educação. Tradução de Maria João Alvarez, Sara Bahia dos Santos e Telmo Mourinho Baptista. Porto: Porto Editora.

Brasil. (1940). Decreto-lei n. 2.848, de 7 de dezembro de 1940. Código Penal. Rio de Janeiro. Recuperado de http://www.planalto.gov.br/ccivil_03/decreto-lei/Del2848compilado.htm

Castells, M. (2005). Internet e sociedade em rede. In D. Moraes (org.). Por uma outra organização: mídia e mundialização cultural e poder (3a ed.) (pp. 255-288). Rio de Janeiro. Editora Record.

Castells, M. (2012). Redes de indignação e esperança: movimentos sociais na era da internet. Rio de Janeiro: Zahar.

Chaves, T. V. (2015). Da Marcha das Vadias às Vadias da Marcha: Discursos sobre a mulher e o espaço. 2015. 145f. Dissertação (Mestrado em Linguística) - Universidade Estadual de Campinas, Campinas.

Courtine, J. J. (2016). Definição de orientações teóricas e construção de procedimentos em Análise do Discurso. Policromias - Revista de Estudos do Discurso, Imagem e Som, [S.1.], 1(1).

Cozby, P. (2003). Métodos de pesquisa em ciências do comportamento. São Paulo: Atlas.

Daróz, E. P. (2020). Mulheres de/em Atenas? Um imaginário de mulher na atualidade. Revista FSA, 17(3). DOI: 10.12819/2020.17.3.11

Debray, R. (1995). Manifestos midiológicos. Trad. Guilherme João de Freitas Teixeira. Petrópolis/RJ: Vozes.

Dias, C. \& Couto, O. (2011). As redes sociais na divulgação e formação do sujeito do conhecimento: compartilhamento e produção através da circulação de ideias. Linguagem em (Dis)curso, Tubarão, 11(3): 631-648. 
Dias, C. (2012). Sujeito, sociedade e tecnologia: a discursividade da rede (de sentidos). São Paulo. Hucitec.

Dias, C. (2013). Linguagem e tecnologia: uma relação de sentidos. In V. Preti \& C. Dias (org.). Análise do discurso em perspectiva: teoria, método e análise. Santa Maria: UFSM.

Dias, C. (2014). O ensino, a leitura e a escrita: sobre conectividade e mobilidade. Entremeios: revista de estudos do discurso. 9.

Dias, C. (2016). A materialidade digital da mobilidade urbana: espaço, tecnologia e discurso. Linguas e Instrumentos Linguítiscos, 37.

Dias, C. (2018). Análise do Discurso digital. Campinas, SP: Pontes.

Faria, D. O. (2016). Filtros na rede: das relações entre discurso e tecnologia. Tese de Doutorado, Faculdade de Filosofia, Ciências e Letras de Ribeirão Preto, Universidade de São Paulo, Ribeirão Preto. DOI: 10.11606/T.59.2016.tde-11052016-105621

Gadet, F. \& Pêcheux, M. ([1991] 2010). A língua inatingível. O discurso na história da Linguística. Trad. Bethânia Mariani e Maria Elizabeth C. Mello. Campinas: Editora RG.

Galli (2011) A escrita (em cena) no espaço digital da internet. In L. M. S. Romão \& F. C. S. Galli (org.). Rede eletrônica: sentidos e(m) movimento (pp. 37-46). São Carlos, Pedro \& João editores.

Garcia, D. A \& Sousa, L. M. A. (2014). Ler o arquivo hoje: a sociedade em rede e suas andanças no ciberespaço. Conexão Letras. 9(11).

Garcia, D. A \& Sousa, L. M. A. (2015). A sororidade no ciberespaço: laços feministas em militância. Estudos Linguísticos, São Paulo, 44 (3): 991-1008.

Garcia, D. A. \& Sousa, L. M. A. (2014). A Marcha das Vadias nas redes sociais: um discurso da militância? Estudos Linguísticos, São Paulo, 43(3): 1041-1055.

Garcia, D. A. (2014). O silêncio e a voz da mulher na sociedade contemporânea militando por um outro dizer. In A. R. Patti, D. O. Faria, D. Giorgeon, D. A. Garcia, \& L. M. A. Sousa. Textecendo discursos na contemporaneidade. São Carlos: Pedro \& João Editores.

Garcia, D. A. (2017). Uma inscrição no banheiro, um corpo que significa: efeitos de/sobre mulher. In L. M. A. Sousa et al. Travessias em discurso: a língua na história. São Carlos, SP: Pedro e João Editores.

Grigoletto, E., De Nardi, F. S \& Schons, C. R. (2011). Discursos em rede: práticas de (re)produção, movimentos de resistência e constituição de subjetividades no ciberespaço. Recife: UFPE.

Guilhaumou, J. \& Maldidier, D. (2010). Efeitos de arquivo. A análise do discurso no lado da história. In E. P. Orlandi (org.) Gestos de Leitura. Campinas: Editora da Unicamp.

Hollanda, H. B. (org.) (2018). Explosão feminista: arte, cultura, política e universidade. São Paulo: Companhia das Letras. 
Lagazzi, S. M. (1988). O desafio de dizer não. Campinas, SP: Pontes.

Lagazzi, S. M. (2009). Recorte significante na memória. In F. Indursky \& M. C. LeandroFerreira, S. Mittmann (org.). O discurso na contemporaneidade: materialidades e fronteiras. São Carlos, SP: Claraluz.

Leandro-Ferreira, M. C. (2000). Da ambiguidade ao equívoco: a resistência da língua nos limites da sintaxe e do discurso. Porto Alegre: Editora da Universidade Federal do Rio Grande do Sul.

Leandro-Ferreira, M. C. (2010). Análise do discurso e suas interfaces: o lugar do sujeito na trama do discurso. Organon, Porto Alegre, 24(48): 17-34.

Leandro-Ferreira, M. C. (2011). Análise de discurso e seus objetos. In E. A Rodrigues, G. L. dos Santos \& L. K. A. C. Branco (org.). Análise de discurso no Brasil: pensando o impensado sempre. Uma homenagem a Eni Orlandi (pp. 343-359). Campinas, SP: Editora RG.

Leandro-Ferreira, M. C. (2012). Memória discursiva em funcionamento. In L. M. S. Romão \& F. S. Correa. Conceitos discursivos em rede. São Carlos: Pedro \& João Editores.

Lévy, P. (1999). Cibercultura. São Paulo. Editora 34.

Machado, L. (2017). Justiça manda soltar homem que assediou mulher em ônibus e tem 5 passagens por estupro. G1, São Paulo. Recuperado de https://g1.globo.com/saopaulo/noticia/justica-manda-soltar-homem-que-assediou-mulher-em-onibus-e-tem-5passagens-por-estupro.ghtml

Maldidier, D. (2003). A inquietação do discurso - (re)ler Michel Pêcheux hoje. Campinas, SP: Pontes.

Mariani, B. (1996). O PCB e a Imprensa: os comunistas no imaginário dos jornais (19221989). Campinas, SP: Editora Unicamp e Editora Revan.

Mariani, B. (2006). Sentido de subjetividade: imprensa e psicanálise. Polifonia, Cuiabá, 12(1): 21-45.

Mariani, B. (2009). Sujeitos e discursos contemporâneos. In F. Indursky, M. C. LeandroFerreira \& S. Mitimman (org.). O discurso na contemporaneidade: materialidades $e$ fronteiras. São Carlos: Claraluz.

Minayo, M. C. S. (org.) (2010). Pesquisa social: teoria, método e criatividade (29a ed.). Rio de Janeiro: Vozes.

Mittmann, S. (2005). Apresentação do texto Lecture et Mémoire: projet de recherche. In F. Indursky, M. C. Leandro-Ferreira \& S. Mitimman (org.). Michel Pêcheux e a análise do discurso: uma relação de nunca acabar (pp. 245-250). São Carlos: Claraluz.

Mittmann, S. (2011). Alguns apontamentos sobre militância digital. In E. Grigoletto, F. S. Nardi \& C. R. Schons (org.). Discursos em rede: práticas de (re)produção, movimentos de resistência e constituição de subjetividades no ciberespaço. Recife: UFPE. 
Moraes, D. (2001). Ativismo digital. Recuperado de http://www.bocc.ubi.pt/pag/moraesdenis-ativismo-digital.pdf

Mussalim, F. \& Bentes, A. C. (org.). (2003). Introdução à lingüística: domínios e fronteiras. v. 3. São Paulo: Cortez.

Nascimento, L; Souza, G; Torezani, J. Lambe-lambe: a arte da intervenção urbana. In: CONGRESSO DE CIÊNCIAS DA COMUNICAÇÃO NA REGIÃO NORDESTE, 19., 2017, Fortaleza. Anais... Fortaleza, 2017. Disponível em: http://www.portalintercom.org.br/anais/nordeste2017/resumos/R57-0431-1.pdf . Acesso em: 22 abr. 2019.

Nunes, J. H. (2005). Leitura de arquivo: historicidade e compreensão. Disponível em: http://anaisdosead.com.br/2SEAD/SIMPOSIOS/JoseHortaNunes.pdf

Oliveira, Di. (2015) Lambe-lambe: resistência à verticalização do Baixo Augusta. 2015. 24 f. Monografia (Especialização em Gestão de Projetos Culturais e Organização de Eventos) Centro de Estudos Latino Americanos sobre Cultura e Comunicação, Escola de Comunicações e Artes, Universidade de São Paulo, São Paulo.

Orlandi, E. P. (1988). Discurso e leitura. Campinas, SP: Editora da Unicamp.

Orlandi, E. P. (1990). Terra à vista: discurso do confronto: velho e novo mundo. São Paulo: Campinas. Editora Unicamp.

Orlandi, E. P. (1995). Texto e Discurso. Organon, 9(23): 111-118. DOI: 10.22456/22388915.29365

Orlandi, E. P. (1996). Interpretação: Autoria, leitura e efeitos do trabalho simbólico. São Paulo: Vozes.

Orlandi, E. P. (1998). Interpretação: autoria, leitura e efeitos do trabalho simbólico. Petrópolis, RJ: Vozes.

Orlandi, E. P. (1999). Maio de 1968: os silêncios da memória. In P. Achard et. al. Papel da memória. Campinas. Pontes.

Orlandi, E. P. (2001). Discurso e texto: formulação e circulação dos sentidos. Campinas: Pontes.

Orlandi, E. P. (2002). A análise do discurso e seus entre-meios: notas a sua história no Brasil. Cad. Est. Ling., Campinas, (42): 21-40.

Orlandi, E. P. (2002). Análise de Discurso: princípios e procedimentos. Campinas: Pontes.

Orlandi, E. P. (2002). Língua e conhecimento linguístico: para uma história das idéias no Brasil. São Paulo: Cortez.

Orlandi, E. P. (2003a). Para uma enciclopédia da cidade. Campinas, SP: Pontes, Labeurb/Unicamp. 
Orlandi, E. P. (2003b). A linguagem e seu funcionamento: as formas de discurso (4a ed.). Campinas, SP: Pontes.

Orlandi, E. P. (2004). Cidade dos Sentidos. Campinas: Pontes.

Orlandi, E. P. (2006). Discurso e textualidade. Campinas: Pontes.

Orlandi, E. P. (2007). Análise do Discurso Princípios e Procedimentos (7a ed.). Campinas, SP: Pontes.

Orlandi, E. P. (2009). Análise de discurso: princípios e procedimentos (7a ed.). Campinas: Pontes.

Orlandi, E. P. (2010). Análise de discurso. In E. P. Orlandi \& S. Lagazzi-Rodrigues (org.). Introdução às ciências da linguagem - discurso e textualidade (pp. 11-31). Campinas, SP: Pontes editores.

Orlandi, E. P. (2012). Discurso em análise: sujeito, sentido e ideologia (2a ed.). Campinas, SP: Pontes Editores.

Orlandi, E. P. (2014). Parkour: corpo e espaço reescrevem o sujeito. Língua e Instrumentos Linguísticos, 34: 74-87. Recuperado de http://www.revistalinguas.com/edicao34/artigo4.pdf

Patti, A. R. (2012). A noção de sujeito discursivo. Fragmentum, 1(32): 18-21. DOI: $10.5902 / 4731$

Payer, M. O. (2005). Linguagem e sociedade contemporânea - sujeito, mídias, mercado. Rua Revista do Núcleo de Desenvolvimento em Criatividade da Unicamp, 11: 09-25.

Pêcheux, M. \& Fuchs, C. ([1975] 2014). A propósito da análise automática do discurso: atualização e perspectivas (1975). In F. Gadet \& T. Hak (org.). Por uma análise automática do discurso: uma introdução à obra de Michel Pêcheux (5a ed.) (pp. 159-249). Campinas: Unicamp.

Pêcheux, M. ([1969] 2010]). Análise automática do discurso. In F. Gadet \& T. Hak (org.). Por uma análise automática do discurso: uma introdução à obra de Michel Pêcheux. Campinas: Editora da Unicamp.

Pêcheux, M. ([1975] 1988). Semântica e Discurso: uma crítica a afirmação do óbvio (4a ed.). Campinas, SP: Editora Unicamp.

Pêcheux, M. ([1982] 2010). Ler o arquivo hoje. In E. P. Orlandi (org.). Gestos de leitura: da história no discurso (3a ed.) (pp. 49-60). Campinas (São Paulo): Editora da Unicamp.

Pêcheux, M. ([1983] 1999). Papel da memória. In P. Achard et. al. Papel da memória. Campinas, SP: Pontes Editores.

Pêcheux, M. ([1983] 2006). O Discurso: estrutura ou acontecimento (4a ed.). Campinas, SP: Pontes. 
Pêcheux, M. ([1983] 2008). O discurso: estrutura ou acontecimento (5a ed.). Campinas: Pontes Editores.

Pêcheux, M. ([1983] 2020). Papel da Memória. In P. Achard et. al. Papel da memória. Campinas, SP: Pontes Editores.

Pêcheux, M. (1997). Análise automática do discurso (AAD-69). In F. Gadet \& T. Halk (org.). Por uma análise automática do discurso: uma introdução a obra de Michel Pêcheux (3a ed.). Campinas, SP: Editora da Unicamp.

Pêcheux, M. (2011). A aplicação dos conceitos da linguística para a melhoria das técnicas de análise de conteúdo. In Orlandi, E. P. Análise de Discurso: Michel Pêcheux (pp. 203-226). Campinas: Pontes.

Pêcheux, M. (2016). Questões iniciais. In B. Conein, J-J. Courtine, F. Gadet, J-M. Maradin, M. Pêcheux (org.). Materialidades Discursivas. Campinas: Editora da Unicamp.

Pereira, D. D. S. (2018). Funcionamento discursivo das hashtags: um olhar para a \#somostodos. 2018. 82 f. Dissertação (Mestrado em Divulgação Científica e Cultural) Instituto de Estudos da Linguagem, Universidade Estadual de Campinas, Campinas. Recuperado de http://repositorio.unicamp.br/jspui/bitstream/REPOSIP/332362/1/Pereira_DeborahDannyD aSilva_M.pdf

Petri, V. (2013). O funcionamento do movimento pendular próprio às análises discursivas na construção do "dispositivo experimental" da Análise de Discurso. In V. Petri \& C. Dias (org.). Análise do discurso em perspectiva: teoria, método e análise. Santa Maria: Editora da UFSM.

Ramos, P. E. G. T. \& Martins, A. O. (2018). Reflexões sobre a rede social Instagram: do aplicativo à Textualidade. Texto Digital, Florianópolis, 14(2): 117-133. DOI: $10.5007 / 1807-9288.2018 \mathrm{v} 14 \mathrm{n} 2 \mathrm{p} 117$

Robin, R. (2016). A memória saturada. Tradução de Cristiane Dias e Greciely Costa. Campinas, SP: Editora Unicamp.

Romão, L. M. S. (2005). De areia e de silício: as tramas do discurso no livro eletrônico. Espetáculo, Madrid, 31.

Romão, L. M. S. (2011). Exposições do museu da língua portuguesa: arquivo e acontecimento e $(m)$ discurso. São Carlos: Pedro \& João.

Romão, L. M. S., Leandro-Ferreira, M. C. \& Dela-Silva, S. (2011). Arquivo. In B. Mariani, V. Medeiros \& S. Dela-Silva. Discurso, arquivo e... (pp. 15). Rio de Janeiro: Editora 7 letras.

Sanches, R. D. (2018). Corpus Alienum: efeitos do discurso das novas dietas, corpo-projeto e mídia. Tese de Doutorado, Faculdade de Filosofia, Ciências e Letras de Ribeirão Preto, Universidade de São Paulo, Ribeirão Preto. DOI: 10.11606/T.59.2018.tde-01082018110612 
Scherer, A. E. (2010). A escrit(ur)a de si: uma história do sujeito pela alteridade. In B. M. Eckert-Hoff \& M. J. R. F. Coracini (org.). Escrit(ur)a de si e alteridade no espaço papeltela (pp. 107-120). Campinas, SP: Mercado das Letras.

Serrani, S. M. (1998). Identidade e segundas línguas. In I. Signorini (org.). Língua(gem) e identidade. Campinas/São Paulo: FAPESP/FAEP Unicamp/Mercado das Letras.

Sousa, L. M. A. \& Sanches, R. D. (2018). O corpo do/no discurso midiático das dietas: efeitos do novo e da novidade. Rev. Famecos [online], Porto Alegre, 25(1).

Sousa, L. M. A. (2016). O real e a poesia nos entremeios litorâneos de Pêcheux e Lacan. Fragmentum. 47.

Walty, I. L. C. (2014). A Rua da Literatura e a Literatura da Rua. Belo Horizonte. Editora UFMG.

Warken, J. (2016). Lambe-lambes feministas espalham poesia e protesto pelas ruas. $M$ de Mulher [online]. Recuperado de https://mdemulher.abril.com.br/estilo-de-vida/lambelambes-feministas-espalham-poesia-e-protesto-pelas-ruas/ 